\title{
For a history of childhood and of his education in contemporary Italy. Interpretations and perspectives of research (Bilingual Edition: English/Italian) ${ }^{1}$
}

\author{
Per una storia dell'infanzia e della sua educazione nell'Italia contemporanea. \\ Interpretazioni e prospettive di ricerca
}

Para uma história da infância e sua educação na Itália contemporânea. Interpretações e perspectivas de pesquisa

\author{
ROBERTO SANI ${ }^{2}$
}

\begin{abstract}
The history of childhood and childhood education has experienced, in Italy, a real development only in the last forty years. The reason of such a delay is due to several factors. First of all, the prevalence in the Italian historiography, until the seventies, of the ethical-political matrix derived from Hegel's idealism, which wasn't avoided not even by the Marxist historians. Secondly, the serious delay with which the historical-pedagogical research - for a too long period of time confined within the narrow limits of the history of pedagogical doctrines and of the philosophical theories of education- has developed its own cultural and epistemological identity and autonomy and the methodologies and conceptual frameworks typical of the historiographical research. This paper is based on the awareness that the history of childhood for the «elusive» character of the object to be studied and for its being placed in a border area between different sectors and fields of research - involves a complex and structured approach,
\end{abstract}

1 The members of Editorial Commission of Cadernos de História da Educação are grateful for the intermediation of Prof. Dr. Maria Helena Camara Bastos of the Pontifícia Universidade Católica do Rio Grande do Sul (Porto Alegre, Rio Grande do Sul, Brazil) in sending this important contribution from Prof. Dr. Roberto Sani of the University of Macerata (Italy).

${ }^{2}$ Full professor of History od Education at the Department of Education, Cultural Heritage and Tourism at the University of Macerata, Italy. Coordinator of the $\mathrm{PhD}$ Board of Theory and History of Education (Macerata University). Director of Center of Study and Research on the history of University of Macerata and member of the Steering Committee of the Centre of Documentation and Research on the history of the textbook and children's literature of the same University. Promoter and editor of the international journal History of Education \& Children's Literature. E-mail: roberto.sani@unimc.it 
able to allow different levels of analysis and reading; thus requiring the contribution of various historiographical skills in an interdisciplinary perspective (social history, that of institutions and educational practices, but also the history of mentalities, cultural processes, etc.). It consists of two separate parts, and is meant to focus on the previous investigations, on the current situation and on the future developments in this field of research. In the first part, after having provided an extensive review of the research and studies on the history of childhood and on childhood education published in Italy in the last decades, the Author analyzes certain issues relating to the methodological and historiographical organization of these studies. In particular, he focuses on some themes of the history of childhood and its education little or not at all investigated by scholars, as well as on the trend typical of several papers appeared in the last decades to define and interpret the historical events of childhood on the basis of an approach using «models», derived, a little bit uncritically, from the social sciences, which does not seem to adequately take into consideration the complexity of the educational and culturalhistorical processes that have affected Italy. In the second part of the work, in order to facilitate the expansion and the refinement of the historical investigation on this issue, the Author aims to illustrate the importance of certain research and of some sources still little or not used by scholars to analyze the history of his childhood and education in contemporary Italy (XIX-XX centuries). For what concerns this aspect, a special attention is given to the role - still largely to be explored - of the Catholic Church in the support and in the religious and civil education of childhood, as well as in the construction of a certain children imagination in the adult world.

\section{Sommario}

La storia dell'infanzia e dell'educazione infantile ha conosciuto, in Italia, un effettivo sviluppo solamente nel corso degli ultimi quarant'anni. All'origine di siffatto ritardo si collocano diversi fattori. In primo luogo, il prevalere, fino agli anni Settanta, nell'ambito della storiografia italiana, della matrice etico-politica di derivazione hegeliano-idealistica, alla quale non hanno saputo sottrarsi neppure gli storici di formazione marxista. In secondo luogo, il grave ritardo con cui la ricerca storico-pedagogica - troppo a lungo confinata entro gli angusti limiti della storia delle dottrine pedagogiche e delle teorie filosofiche dell'educazione - ha maturato la propria identità e autonomia epistemologica e culturale e si è dotata delle metodologie e dei quadri concettuali propri dell'indagine storiografica. Il presente contributo si fonda sulla consapevolezza che la storia dell'infanzia - per il carattere «sfuggente» dell'oggetto da studiare e per il suo collocarsi in una zona di confine tra differenti settori e ambiti di ricerca - implica un approccio articolato e complesso, capace di consentire diversi livelli di analisi e di lettura; necessita quindi dell'apporto di molteplici competenze storiografiche in prospettiva interdisciplinare (la storia sociale, quella delle istituzioni e delle pratiche educative, ma anche la storia della mentalità, dei processi culturali ecc.). Esso si compone di due parti distinte e intende focalizzare l'attenzione sulle indagini compiute, sulla situazione attuale e sui futuri sviluppi della ricerca nel settore. Nella prima parte, dopo aver fornito un'ampia rassegna delle ricerche e degli studi dedicati alla storia dell'infanzia e dell'educazione infantile pubblicati in Italia negli ultimi decenni, l'Autore approfondisce talune questioni concernenti l'impostazione metodologica e storiografica di tali studi. In particolare, egli si sofferma su talune tematiche e questioni della storia dell'infanzia e della sua educazione ancora poco o per nulla indagate dagli studiosi, nonché sulla tendenza comune a diversi contributi apparsi negli ultimi decenni a definire e ad interpretare le vicende storiche dell 'infanzia sulla base di un approccio per «modelli» desunto un po' acriticamente dalle scienze sociali, il quale, alla prova dei fatti, non sembra tenere adeguatamente presente la complessità dei processi storico-culturali ed educativi che hanno interessato la penisola. Nella seconda parte del lavoro, allo scopo di favorire l'ampliamento e l'affinamento 
dell'indagine storica su questo versante, l'Autore si propone di illustrare l'importanza che rivestono taluni itinerari di ricerca e talune fonti ancora poco o per nulla utilizzate dagli studiosi ai fini dell'approfondimento della storia dell'infanzia e della sua educazione nell'Italia contemporanea (secoli XIX-XX). Relativamente a questo aspetto, un'attenzione particolare è riservata al ruolo - ancora in larga misura da approfondire - esercitato dalla Chiesa cattolica nell'assistenza e nell'educazione religiosa e civile dell'infanzia, come del resto nella costruzione di un determinato immaginario infantile nel mondo adulto.

\section{Resumo}

A história da educação infantil e da infância conheceu, na Itália, um verdadeiro desenvolvimento somente nos últimos quarenta anos. A origem de tal atraso são colocados em vários factores. Em primeiro lugar, a prevalência, até que os setenta anos, como parte da historiografia italiana, a matriz derivada do ético-político - idealista de Hegel, que não tenham ainda sido capaz de evitar a formação de historiadores marxistas. Em segundo lugar, o grave atraso no histórico- pedagógico - levando tempo demais sendo confinados dentro dos limites estreitos da história das doutrinas teorias pedagógicas e filosóficas da educação - tem desenvolvido a sua própria identidade, autonomia, características culturais, epistemológicos metodologias e estruturas conceituais próprias do levantamento historiográfico. Esta contribuição é baseada na consciência de que a história da infância - para o personagem objeto «indescritivel» a ser estudado e colocou-a em uma área de fronteira entre diferentes setores e campos de pesquisa - envolve uma abordagem complexa e multi-facetada, capaz de permitir diferentes níveis de análise e leitura; exige, portanto, a entrada de várias habilidades historiográficas em perspectiva interdisciplinar (história social, a de instituições e práticas de ensino, mas também a história das mentalidades, processos culturais, etc.). É composto por duas partes distintas, e pretende concentrar-se nas investigações realizadas, a situação atual e desenvolvimentos futuros no campo da pesquisa. Na primeira parte, após a apresentação de uma extensa revisão das pesquisas e estudos dedicado à história da educação infantil e da infância publicada na Itália nas últimas décadas, o autor investiga certas questões relativas à metodologia e historiografia desses estudos. Em particular, ele se concentra em determinados temas e questões da história da infância e da sua educação ainda pouco ou não investigado por estudiosos, bem como a tendência comum em diversas contribuições têm surgido nas últimas décadas para definir e interpretar os acontecimentos históricos de' infância com base em uma abordagem de «modelos» derivando um pouco de forma acrítica das ciências sociais, o que, na evidência dos fatos, não parecem ter devidamente em conta a complexidade dos processos de ensino e histórico-culturais que afetaram a península. Na segunda parte do trabalho, a fim de facilitar a expansão e o aperfeiçoamento da investigação histórica sobre este assunto, o autor tem como objetivo ilustrar a importância de certas rotas de pesquisa e algumas fontes ainda pouco ou nunca usadas, por estudiosos para aprofundar a história de sua infância e educação na Itália contemporânea (séculos XIX-XX). No que diz respeito a este aspecto, é dada especial atenção ao papel - ainda em grande parte a ser explorado - exercida pela Igreja Católica e na assistência da infância religiosa e civil, como a construção de um certo imaginário infantil em mundo adulto. 


\section{The recent historiography on childhood and childhood education in Italy}

It has been rightly observed that «the history of childhood, and its identification as a historiographical object, is a recent acquisition of our culture» ${ }^{3}$. For a long time, in fact, despite the lively development of this study field in France and in the Anglo-Saxon countries, the historical research in Italy - including that of pedagogical and educational orientation - have paid little attention to the children's social conditions and to the adult's idea of childhood in the different historical periods ${ }^{4}$.

This is due to several factors. First of all, the prevalence, until the seventies, of an Hegelian-idealistic ethical-political attitude in the Italian historiography, that influenced also the Marxist historians, despite their strong ideological opposition towards the traditional historiographical orientations: in their approach, in fact, we can easily find «the permanence of an "idealistic" mental structure, despite their following the Marxist principles $»^{5}$. Secondly, the serious delay with which the historical and educational research, confined for a too long time within the narrow limits of the history of the pedagogical doctrines and philosophical theories on education, has gained its epistemological and cultural identity / autonomy and adopted methodologies and tools typical of a historiographical survey ${ }^{6}$.

In recent decades, however, the studies on the history of childhood have recorded a significant increase also in our country. After the first, pioneering works by Dina Bertoni Jovine and Leonardo Trisciuzzi ${ }^{7}$, the framework was enriched by a series of original and comprehensive research, characterized, in some cases, by an interdisciplinary approach and the use of documentary sources and materials never used previously. We refer, first of all, to the interesting surveys carried out by Egle Becchi and the research group of Pavia,

\footnotetext{
${ }^{3}$ E. Catarsi, L'infanzia nell'Italia unita. Riflessioni metodologiche e prospettive di ricerca, in A.M. Bernardinis, E. Bosna, F. Cambi, E. Catarsi, L. Trisciuzzi, Storiografia dell'Infanzia. Problemi e metodi, Ferrara, Biblioteca del Bollettino CIRSE, 1991, pp. 49-71.

${ }^{4}$ On a general level, see N. Tranfaglia (ed.), L'Italia unita nella storiografia del secondo dopoguerra, Milano, Feltrinelli, 1980; e P. Rossi (ed.), La storiografia contemporanea. Indirizzi e problemi, Milano, Il Saggiatore, 1987; C. Cassina (ed.), La storiografia sull'Italia contemporanea, Pisa, Giardini, 1990. With specific reference to the pedagogical and educational historiography see:. E. Becchi, A. Semeraro (edd.), Archivi d'infanzia: per una storiografia della prima età, Scandicci, La Nuova Italia, 2001; and E. Becchi, Il bambino di ieri: breve storia di una storiografia, in «Studi sulla Formazione», XIII (2010), n. 1, pp. 9-24.

5 D. Coli, Idealismo e marxismo nella storiografia italiana degli anni '50 e '60, in P. Rossi (ed.), La storiografia contemporanea. Indirizzi e problemi, cit., p. 51 (but see also the other brilliant observations contained in this essay, pp. 38-58). On Marxist historiography in Italy see also: L. Masella, Passato e presente nel dibattito storiografico: storici marxisti e mutamento della società italiana (1955-1970), Bari, De Donato, 1979. On the difficulties the social history encountered in our country and the new research fields established in France and Britain, see the reflections in in A.M. Banti, La storia sociale: un paradigma introvabile?, in C. Cassina (ed.), La storiografia sull'Italia contemporanea, cit., pp. 183-208.

${ }^{6}$ See A. Santoni Rugiu, Dalla storia dell'ideologia pedagogica alla storia sociale dell'educazione, in A. Santoni Rugiu, G. Trebisacce (edd.), I problemi epistemologici e metodologici della ricerca storicoeducativa, Cosenza, Pellegrini, 1983, pp. 61-70; R. Fornaca, La ricerca storico-pedagogica, Scandicci, La Nuova Italia, 1988; F. Cambi, La ricerca storico-educativa in Italia 1945-1990, Milano, Mursia, 1992, pp. 11-54; e R. Fornaca, La ricerca storico-educativa. Riflessioni e prospettive, in «Nuovo Bollettino CIRSE», I (2006), n. 1-2, pp. 21-26.

7 D. Bertoni Jovine, L'alienazione dell'infanzia, Roma, Editori Riuniti, 1963; L. Trisciuzzi, La scoperta dell'infanzia, Firenze, Le Monnier, 1976.
} 
which is gradually expanding its study interests, also establishing fruitful collaborations and synergies with scholars and researchers beyond the Alps ${ }^{8}$.

Among the most interesting results of the work of this group we remember Storia dell'infanzia edited by Egle Becchi and Dominique Julia: a largely successful attempt to reconstruct in a broad and organic synthesis the knowledge acquired by the European historiography on the children's situation from the ancient times to the present ${ }^{9}$.

With specific reference to the Italian reality of the nineteenth and twentieth centuries we have to mention also some local history contributions10, and, above all, Franco Cambi and Simonetta Ulivieri's valuable work on Storia dell'infanzia nell'Italia liberale, which effectively investigated aspects of social history and education (childhood conditions, educational practices etc.), as well as those relating the history of mentalities and the collective imagination (ideas, ideologies, "images" of childhood etc.) ${ }^{11}$.

An interesting opportunity for discussion among historians of pedagogy and scholars of social history and politics with respect to the condition of children in contemporary Italy was represented, at the beginning of the nineties, by the interdisciplinary seminar on the topic Il bambino nella storia, promoted in Perugia in 1991 by the research group coordinated by Maria Cristina Giuntella ${ }^{12}$. This first meeting was followed a few years later, by the equally significant one promoted by the École Française de Rome on the theme Pédagogie et liturgie nationale dans l'Italie post-unitaire. Histoire et historiographie de l'enfance ${ }^{13}$.

Among the papers on the history and education of childhood that have been published in Italy in recent decades, finally, we remember the valuable collections of studies on Le bambine nella storia dell'educazione, edited by Simonetta Ulivieri ${ }^{14}$, Itinerari nella storia dell'infanzia, edited by Ulivieri and Carmela Covato15; and, finally, Infanzia, educazione e società in Italia tra Otto e Novecento, edited by Luciano Caimi ${ }^{16}$.

\footnotetext{
${ }^{8}$ See in particolar E. Becchi (ed.), Il bambino sociale. Privatizzazione e deprivatizzazione dell'infanzia, Milano, Feltrinelli, 1979; E. Becchi, M. Ferrari, M. Grandini, S. Micotti, Per una storia dell'infanzia come figura educativa, in E. Becchi (a cura di), Storia dell'educazione, Scandicci, La Nuova Italia, 1987; R. Balzarini et alii, Segni d'infanzia. Crescere come re nel Seicento, Milano, Franco Angeli, 1991; E. Becchi, I bambini nella storia, Roma-Bari, Laterza, 1994; Q. Antonelli, E. Becchi (edd.), Scritture bambine. Testi infantili tra passato e presente, Roma-Bari, Laterza, 1995; E. Becchi, A. Semeraro (edd.), Archivi d'infanzia. Per una storiografia della prima età, Scandicci, La Nuova Italia, 2001; M. Ferrari (ed.), I bambini di una volta. Problemi di metodo. Studi per Egle Becchi, Milano, Franco Angeli, 2006.

${ }^{9}$ E. Becchi, D. Julia (edd.), Storia dell'Infanzia, Roma-Bari, Laterza, 1996, 2 voll.

${ }^{10}$ See F. Della Peruta, Infanzia e famiglia nella prima metà dell'Ottocento, «Studi Storici», 1979, n. 3, pp. 473-491; A.M. Bernardinis (ed.), Il bambino e la sua cultura nella Padova dell'Ottocento, Comune di Padova, Padova 1981; L. Dalle Nogare, L. Finocchi (edd.), Nascere, sopravvivere e crescere nella Lombardia dell'Ottocento (1815-1915), Milano, Silvana Editoriale, 1981; Comune di Modena, Per amore e per forza. L'infanzia tra Ottocento e Novecento, Modena, Edizioni Panini, 1987.

${ }^{11}$ See F. Cambi, S. Ulivieri, Storia dell'infanzia nell'Italia liberale, Scandicci, La Nuova Italia, 1988.

${ }^{12}$ See the proceedings in M.C. Giuntella, I. Nardi (edd.), Il bambino nella storia. Atti del Seminario di Studi Interdisciplinare (Perugia, 14-15 giugno 1991), Napoli, ESI, 1993.

${ }^{13}$ Pédagogie et liturgie nationale dans l'Italie post-unitaire. Histoire et historiographie de l'enfance, in «Mélanges de l'École française de Rome. Italie et Méditerranée», 109 (1997), n. 1, pp. 3-483.

${ }^{14} \mathrm{~S}$. Ulivieri (ed.), Le bambine nella storia dell'educazione, Roma-Bari, Laterza, 1999.

15 C. Covato, S. Ulivieri (edd.), Itinerari nella storia dell'infanzia. Bambine e bambini, modelli pedagogici e stili educativi, Milano, Unicopli, 2001.

${ }^{16}$ L. Caimi (ed.), Infanzia, educazione e società in Italia tra Otto e Novecento. Interpretazioni, prospettive di ricerca, esperienze in Sardegna, Sassari, EDES, 1997.
} 
We believe, furthermore, that two convergent papers have influenced the development of what seems to be now, also in Italy, a specific and independent area of research:

1) First of all, the comparison with the studies and research on the history of childhood started in France, in Germany and in the Anglo-Saxon countries. We refer, in particular, to the fundamental work by Philippe Aries on L'enfant et la vie familiale sous l'ancien régime (1960) and to his following studies and to those of other authors on his same line of interpretation ${ }^{17}$; as well as to the research coordinated by Lloyd de Mause and collected in The history of childhood (1974), which proposes an interpretation of the meaning and the living conditions of childhood radically different from that by Ariès ${ }^{18}$; to the interesting paper by Dieter Richter on Das fremde Kind. Zur Entstehung der Kindheitsbilder des burgerlichen Zeitalsters (1987), which analyses the idea of childhood in modern times through the use of narrative sources of different kind and origin ${ }^{19}$; and, finally, to some large-scale research recently developed in Europe ${ }^{20}$;

${ }^{17} \mathrm{Ph}$. Ariès's work (Paris, Plon, 1960), translated into Italian in 1968 with the title Padri e figli nell'Europa medievale e moderna, was reprinted several times in our country. See also Ariès's other works such as: Le rôle nouveau de la mère et de l'enfant dans la famille moderne, in "Carnets de l'Enfance», giugno 1969, n. 10, pp. 36-43; la Préface à la nouvelle édition of the book L'enfant et la vie familiale... (Paris, Editions du Seuil, 1973, pp. I-XX); Enfant et société. Période moderne. Rapport introductif, in «Annales de Démographie Historique», XI (1973), pp. 211-224; Educazione, in Enciclopedia, Torino, Einaudi, 1978, V, pp. 251-259; Pour une histoire de la vie privée, in Ph. Ariès, G. Duby (edd.), Histoire de la vie privée. III. De la Renaissance aux Lumières, Paris, Editions du Seuil, 1986, pp. 7-19; J.-B. Pontalis, F. Gontheret, Conversazione con Ph. Ariès, in Il mondo dell'infanzia, it. translation, Roma, Savelli, 1981. On the debate around $\mathrm{Ph}$. Ariès's work see the careful reconstruction by E. Becchi, D. Julia, Storia dell'infanzia, storia senza parole?, in Eads. (edd.), Storia dell'Infanzia. 1. Dall'antichità al Seicento, cit., pp. XII-XXVII. A deep analysis of Ph. Ariès's paper to the historiography of childhood is contained in M.T. Maiocchi (ed. by), Edipo in società. Nascita del sentimento familiare e ideale dell'infanzia, Milano, Feltrinelli, 1983. On the same line of interpretation of $\mathrm{Ph}$. Ariès we remember: J. Gelis, M. Laget, M.F. Morel, Entrer dans la vie. Naissances et enfances dans la France traditionelle, Paris, Gallimard, 1980; Enfant et société, "Annales de Démographie Historique», XI (1970), special issue.

${ }^{18}$ New York, Psychohistory Press, 1974-75 (a partial translation of the work has appeared in Italy under the title: Storia dell'infanzia, Milano, Emme, 1983). On the limits and ambiguities of Lloyd De Mause's approach to the history of childhood and of the group of scholars who refer to the address of psychohistory, see the brilliant critique proposed by J. Topolski, La storiografia contemporanea, Roma, Editori Riuniti, Marsilio, 1981, pp. 242-244; and, later, by G. Starace, Le storie, la storia. Psicoanalisi e mutamento, Venezia, Marsilio, 1989, p. 97. See also L. Stone, The Massacre of the Innocents, in «New York Review of Book», $14^{\text {th }}$ November 1974, n. 18, pp. 25-31.

${ }^{19}$ Frankfurt am Main, Fischer Verlag, 1987 (see the italian translation edited by P. Viti: Il bambino estraneo. La nascita dell'immagine dell'infanzia nel mondo borghese, Scandicci, La Nuova Italia, 1992). On childhood representation through literary sources see also: J. Calvet, L'enfants dans la littérature française. Des origines à 1870, Paris, Lanore, 1930; P. Coveney, The image of Childhood. The individual and society: a study of the theme in English literature, London, Penguin, 1967; K. Arnold, Kind und Gesellschaft in Mittelalter und Reinaissance. Beitrage und texte zur Geschichte der Kindheit, Paderbon, Schoningh, 1980; and the essays in D. Escarpit (ed.), The portrayal of the Child in Children's Literature, Munchen-New York, P. Lang, 1985.

${ }^{20}$ See in particular: B. Delgado, Historia de la infancia, Ariel, Barcelona, 1998 (it. translation: Bari, Dedalo, 2002); H. Cunningham, Children \& Childhood in Western Society since 1500 (Studies In Modern History), London, Routledge, 1996 (it. translation: Bologna, Il Mulino, 1997); Id., The Invention of Childhood, London, BBC Books, 2006; P. Dávila, L.M. Maya (edd.), La infancia en la historia: espacios y representaciones, Donostia, EREIN, 2005, 2 voll.; H. Cazes (ed.), Histoires d'enfants. Représentations et discours de l'enfance sous l'Ancien Régime, Laval, Presses Universitaires de Laval, 2008. 
2) secondly, the adoption of orientations and methodologies of research which only in recent decades have found an adequate reception in our country. We think, for example, to the methodological views and especially to the new investigation lines (the «marginalised», «the history of mentality» etc.) proposed by the historiography of the Annales $^{21}$ and by the Anglo-Saxon social history (Lawrence Stone and the group of scholars around the magazine «Past and Present» ${ }^{22}$ ); as well as to Michel Foucault's epistemological investigations $^{23}$, to Norbert Elias's refined works on the history of civilization processes ${ }^{24}$, to the papers of the American scholars who refer to the Psychohistory (from Erik H. Erikson to David Hunt, from John Demos to the already mentioned Lloyd de Mause) $)^{25}$.

Among the most significant acquisitions and results achieved by the research and studies carried out in recent decades in our country, it's worth mentioning:

a) the awareness that the history of childhood - for the "elusiveness" of the object to be studied and for its position in a border zone between different sectors and research fields- involves an articulated and complex approach, that allows different levels of analysis and reading; it needs therefore various historiographical skills in an interdisciplinary perspective (social history, the history of institutions and educational practices, but also the history of mentality, of cultural processes etc.);

b) the space and the attention (I think in particular to the research carried out by Egle Becchi and the group of researchers and scholars of Pavia) given to sources and documentary materials for a long time disregarded or completely ignored by the traditional historical and pedagogical research on childhood, at least in our country: the iconography, memoirs, games and toys, children's clothing, the furniture, the illustrated press and children's literature;

c) the commitment in creating a link, in the reconstructions dedicated to childhood and its education, between the social history and that of mentality: two very different perspectives, whose crossing allows to grasp the complex - and sometimes conflicting relationship between the adult world's imagine of childhood and the behaviors and practices that a given society develops towards children.

${ }^{21}$ See T. Stoianovich, La scuola storica francese. Il paradigma delle «Annales», it. translation: Milano, ISEDI, 1978; and above all G. Gemelli, Le «Annales» nel secondo dopoguerra: un paradigma?, in P. Rossi (ed.), La storiografia contemporanea. Indirizzi e problemi, cit., pp. 6-38. For a broad picture of the more recent research orientations on the French nouvelle histoire see: J. Le Goff (edd.), La nuova storia, it. translation Milano, Mondadori, 1980.

22 See J. Simon, The history of education in Past and Present, in «Oxford Review of Education», XXVI (1977), 1, pp. 23-41. See also G. Ricuperati, La storia dell'istruzione nella storiografia contemporanea, in Storia della scuola e storia d'Italia dall'Unità ad oggi, Bari, De Donato, 1982, pp. 83-86.

${ }^{23}$ See P. Veyne, Foucault révolutionne l'histoire, in Id., Comment on écrit l'histoire, Paris, Editions du Seuil, 1973. See also F. Cambi, La storia dell'infanzia. Questioni di metodo, in Storiografia dell'Infanzia. Problemi e metodi, cit., pp. 34-35.

24 See A. Roversi, Norbert Elias e la riscoperta di Kronos, in La storia comparata. Approcci e prospettive, Milano, Il Saggiatore, 1990, pp. 55-70; and the Introduzione by the same Roversi to the Italian edition by N. Elias, Il processo di civilizzazione, Bologna, Il Mulino, 1988, pp. 11-42.

${ }^{25}$ See L. La Penna, La «Psychohistory»: proposte e studi nella storiografia americana, in "Quaderni Storici», XVI (1981), n. 47, pp. 574-604; and Id., La psico-storia americana tra psicoanalisi e psicologia accademica, in P. Rossi (ed.), La storiografia contemporanea. Indirizzi e problemi, cit., pp. 264-284. 
Starting from these important acquisitions, the above mentioned works and, more generally, the various research on the history of childhood developed in recent years, raise a series of problems that are worth being discussed.

A first general issue: while on some significant problems of history and education of childhood we possess, in Italy, numerous and documented research and valuable local investigations, that keep into consideration a time frame sufficiently large to allow comparisons between geographical areas, on other issues and problems the local frameworks and quantitative data are on the whole poor, generic and vague.

Only two examples:

1) the large amount of studies related to phenomena such as children's abandonment in modern and contemporary times ${ }^{26}$ and, conversely, the substantial shortage of serious and documented reconstructions on the various charitable institutions (girls' schools, homes for orphans and abandoned children and orphanages) ${ }^{27}$;

2) we know a lot about the pedagogical debate on the models and systems of child education developed during the nineteenth and twentieth century (from Aportian kindergartens to Froebelian ones, to the methods developed by the Agazzi sisters and Maria Montessori etc) ${ }^{28}$. while we have little information about the actual conditions and

\footnotetext{
${ }^{26}$ Among the most significant works published on the topic in the last decades, we remember: M. Gorni, L. Pellegrini, Un problema di storia sociale. L'infanzia abbandonata in Italia nel secolo XIX, Firenze, La Nuova Italia, 1974; S. Pagano, Gli esposti dell'Ospedale di S. Spirito nel primo Ottocento, in «Ricerche per la Storia Religiosa di Roma», 3 (1979), pp. 353-392; G. Da Molin, L'infanzia abbandonata in Italia nell'età moderna, Bari, Università degli Studi, 1981; the papers in S.I.D.E.S., La demografia storica delle città italiane, Bologna, Clueb, 1982; e in G. Politi, M. Rosa, F. Della Peruta (edd.), Timore e carità. I poveri nell'Italia moderna, Cremona, Annali della Biblioteca statale e Libreria civica, 1982; V. Hunecke, I trovatelli di Milano. Bambini esposti e famiglie espositrici dal XVII al XIX secolo, Bologna, Il Mulino, 1988; G. Di Bello, Senza nome né famiglia. I bambini abbandonati nell'Ottocento, Firenze, Manzuoli, 1989; G. Da Molin, Nati e abbandonati. Aspetti demografici e sociali dell'infanzia abbandonata in Italia nell'età moderna, Bari, Cacucci, 1993; G. Da Molin (ed.), Trovatelli e balie in Italia secc. XVI-XIX. Atti del Convegno "Infanzia abbandonata e baliatico in Italia (secc. XVI-XIX)», Bari, 20-21 maggio 1993), Bari, Cacucci, 1994; A. Carbone, Esposti e orfani nella Puglia dell'Ottocento, Bari, Cacucci, 2000; C. Grandi, «Benedetto chi ti porta, maledetto chi ti manda». L'infanzia abbandonata nel Triveneto (secoli XV-XIX), Treviso, Edizioni Fondazione Benetton Studi Ricerche - Canova, 1997; S. Polenghi, S., Fanciulli soldati: la militarizzazione dell'infanzia abbandonata nell'Europa moderna, Roma, Carocci, 2003; A. Palombarini, Gettatelli e trovatelli: i bambini abbandonati nelle Marche: $16^{\circ}-20^{\circ}$ secc., Ancona, Affinità elettive, 2005.

27 See the picture offered by E. Bressan, E., Carità e assistenza, pubblico e privato: una riflessione storiografica, in M. Taccolini (ed.), Dalla beneficenza alla cultura del dono, Rudiano (Brescia), GAM, 2012, pp. 93-110. Among the rare works on the topic, see: Sistemi di carità, in «Quaderni Storici», XVIII (1983), n. 53 (monography); A. Buttafuoco, Le Mariuccine. Storia di un'istituzione laica, l'asilo Mariuccia, Milano, Franco Angeli, 1985; E. Baio, La condizione delle orfane alla "Stella" di Milano tra Ottocento e Novecento, in «Sanità scienza e storia», 2 (1985), n. 2, pp. 141-178; G. Botti, L. Guidi, L. Valenzi (ed. by), Povertà e beneficenza tra Rivoluzione e Restaurazione, Napoli, Morano, 1989; S. Fronzoni, Lontano dalla madre: forme e istituti dell'esposizione a Bologna nella prima metà dell'Ottocento, in: «Sanità Scienza e Storia», VI (1989), n. 2, pp. 55-76; V. Nuti, Discoli e derelitti. L'infanzia povera dopo l'Unità, Firenze, La Nuova Italia, 1992; A. Groppi, I conservatori della virtù. Donne recluse nella Roma dei papi, Roma-Bari, Laterza, 1994; and A. Semeraro (ed.), L'infanzia e le sue storie in terra d'Otranto, Lecce, Conte, 1999).

${ }^{28}$ As an example, we remember: A. Gambaro, C. Calò, A. Agazzi, Aporti nel primo centenario della morte, Brescia, La Scuola, 1962; R. Mazzetti, Pietro Pasquali, le Agazzi e la riforma del froebelismo in Italia, Roma, Armando, 1962; D. Gasparini, Il pensiero pedagogico di A. Pick, Firenze, C.D.N.S.D., 19681970, 3 voll.; A. Gambaro, Ferrante Aporti e gli asili nel Risorgimento. Storia e critica, in F. Aporti, Scritti pedagogici e lettere, Brescia, La Scuola, 1976, pp. 3-321; E. Catarsi, G. Genovesi, L’infanzia a scuola. L'educazione infantile in Italia dalle sale di custodia alla materna statale, Bergamo, Juvenilia, $1985 ; \mathrm{E}$.
} 
the concrete educational practices implemented in public and private kindergartens transformed, after the national unification, in Charities ${ }^{29}$.

A further datum to be analyzed concerns the prevalence, in some reconstructions, of the descriptive moment of interpretation/ evaluation. The works of synthesis - although valuable in their offering a wide cross section of the life of children during various historical eras - are full of descriptive elements, whose deeper meaning is sometimes difficult to be grasped, as well as it is difficult to find the reference to a specific conceptual framework, to a general interpretative hypothesis.

By contrast, we totally share the remark expressed by certain scholars regarding the presence, even in the papers of history of childhood appeared in our country, of «super interpretative stretches ${ }^{30}$, which had already been found in the foreign historiographical production $^{31}$.

We have to point out, in this regard, that certain general assumptions about the fate of childhood in contemporary society, such as those focusing on the concept of «child

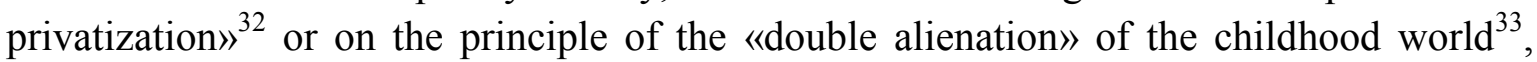
tend to put on a par - at least for what concerns the final outcome, the process results sometimes radically different growth itineraries and experiential paths, such as those that in the nineteenth century and in the first half of the twentieth century characterized the

Catarsi, L'educazione “prescolastica” nell'Italia giolittiana, in Id., L'educazione del popolo. Momenti e figure dell'istruzione popolare nell'Italia liberale, Bergamo, Juvenilia, 1985, pp. 183-211; S.S. Macchietti, La scuola infantile tra politica e pedagogia dall'età aportiana ad oggi, Brescia, La Scuola, 1985; C. Sideri, Ferrante Aporti. Sacerdote, italiano, educatore. Biografia del fondatore delle scuole infantili in Italia sulla base di nuova documentazione inedita, Milano, Franco Angeli, 1999; M. Piseri, Ferrante Aporti nella tradizione educativa lombarda e europea, Brescia, La Scuola, 2008.

${ }^{29}$ On the legislation on the charities in the post-unification period, see: S. Lepre, Le difficoltà dell'assistenza. Le Opere Pie in Italia fra '800 e '900, Roma, Bulzoni, 1988; F. Della Peruta, Le Opere Pie dall'Unità alla Legge Crispi, in «Il Risorgimento. Rivista di storia del Risorgimento e di storia contemporanea», XLIII (1991), n. 2-3, 1991, pp. 173-213; G. Farrell-Vinay, Povertà e politica nell'Ottocento. Le Opere Pie nello Stato liberale, Torino, Paravia, 1997; A. Fiori, Poveri, Opere pie e assistenza dall'Unità al fascismo, Roma, Studium, 2005;

${ }^{30}$ E. Catarsi, L'infanzia nell'Italia unita, cit., pp. 50-51. But see also: C. Pancera, Per una interpretazione della storia dell'infanzia, in «Studi di storia dell'educazione», 4 (1983), n. 3, pp. 46-58.

${ }^{31}$ See intervention a bit dated by rich of stimuli by E. Becchi, Molte infanzie, poche storie, in «Ricerche Pedagogiche», 18 (1983), n. 68-69, pp. 9-10.

${ }_{32}$ See (ed.), Il bambino sociale. Privatizzazione e deprivatizzazione dell'infanzia, Milano, Feltrinelli, 1979.

${ }^{33}$ Franco Cambi and Simonetta Ulivieri wrote about the topic : «The alienation of the middle-class child is connected to conformism, to adult control, to the repression of instincts (of the free game and socialization, of sex) to which he is subjected and, even if it seems to be- compared to that typical of the popular classes, which has the hard form of the exploitation - as a "golden" alienation, it always reveals a real expropriation exerted on the child, on his deeper self. The two alientations - one material and moral, the other spiritual and psychological - are in parallel: they indicate a common destiny of childhood - despite the deep diversity of their paths (the first made of work-marginalization-ignorance / misery, the second of family -conformismcontrol / repression) -, a destiny that emphasizes its total subordination to the adult social world, its noninvolvement (as in self) in the dominant culture (or cultures), the need of appropriation-assimilation of the adults towards that age that is "precious" and "fabulous", but also "perverse" and "deviant". The double alienation acts not only in terms of living conditions, educational / training practices, of actual behaviors, but also through the imagination, tying the mentality to its models even in the most abstract and symbolic forms » (F, Cambi, S. Ulivieri, Storia dell'infanzia nell'Italia liberale, cit., p. 272). 
childhood of the rural and urban proletarian classes, on the one hand, and that of the upper classes and the bourgeois world, on the other.

A few years ago, Enzo Catarsi has appropriately pointed out that, «thinking in terms of social history», we can not «consider the bestial exploitation of children of the working classes and the golden alienation of the children of the rich people in the same way $»^{34}$. Furthermore, beyond the objective difficulty to justify, on a historiography level, equalizations and / or parallels between so different social and cultural conditions, ways of being, life experiences, the underlying risk to certain general interpretations is to reintroduce, in the explanation of the historical events, a sort of ideological framework, more or less up to date and in line with certain trends of the current cultural debate.

Finally, there is a last aspect to be discussed, related to the configuration of much of the research carried out in Italy. We refer to the common trend, found in several articles published in recent decades, to define and interpret the historical events of childhood using an approach based on "models" (essentially three: middle-class childhood, popular urban childhood, rural childhood) that represent the result of more general socio-economic conditions and of the class structure of society.

In the case of post-unitary Italy, it is hard to use these "models", derived from the social sciences, in real historical circumstances and to legitimize their interpretative function without stretching and simplifying the reality. The most prominent example of this difficulty to adapt the models-system to the real Italian historical-cultural processes, can be found in the determination / definition of the so-called «bourgeois model», taken as an expression of the guidelines and strategies of the ruling classes.

\section{2. - The «bourgeois model»: stretches and limits of a methodological and heuristic approach.}

A series of problems take place in the transition from the theoretical definition of the «bourgeois model» to the historical verification of the function and impact that such a model had at the level of cultural choices, training processes, educational and academic practices, social policies, but also of a «childhood sentiment», i.e. the development of a «collective imagination» on the child (intended to acquire a hegemonic role, according to some interpretations).

First of all: the bourgeoisie or the bourgeoisies? In the sixty years from national unification to the rise of Fascism, can we speak, for our country, of the bourgeoisie as a unitary subject from a cultural and political point of view? More precisely: is there a single «bourgeois model», identified tout court with the politically hegemonic one?

The same way in which the unification process took place, the special connotation of the relationship between church and state (considered, of course, not in a diplomatic and institutional sense, but as a factor affecting the civil and cultural life and the individual consciousness), the specific characteristics of the Catholic culture of the time (the difficult relationship with modernity and with its achievements etc.) lead to a great caution in

\footnotetext{
${ }^{34}$ E. Catarsi, L'infanzia nell'Italia unita, cit., p. 51.
} 
adopting a "model" of cultural, social and political relations able to represent without stretches and simplifications the Italian reality. ${ }^{35}$

It could be also pointed out that Italy in the post-unitary period includes very different and complex realities, with different economic, social (North / South, urban / rural, development / underdevelopment etc.), and, above all, cultural systems, intended to deeply affect the features and aspirations of the bourgeois elites and of the local landowners ${ }^{36}$.

The other issue on which focus our attention is that of the role of the Church and of the Italian Catholicism in the history of childhood and of its education in the nineteenth and twentieth century. We don't exaggerate in affirming that, curiously, the Church itself is the great absent or, rather, the forgotten element in the above mentioned historiographical reconstructions.

Such an absence is undoubtedly something to think about. In fact, unless you do not identify the actions of the Church, and of the Catholic world as a whole, with that of the ruling classes, considering their contribution in terms of mere functionality and subordination with respect to the construction of the cultural and ideological / pedagogic bourgeois "model" (in the double meaning of development of guidelines, strategies, educational practices and of elaboration of a particular symbolic representation of childhood), there is a prevalence in considering the specific contribution of the Church as little or no relevant at all, so that its presence / initiative is considered as marginal, episodic, however, not decisive in the general picture. But, from a historiographical point of view, this is something simplistic and reductive.

But we will analyze later the convenience of a study of the function and initiatives of the Church and Catholicism as a whole for the purpose of developing a more comprehensive and convincing framework of the history of childhood and its education in the nineteenth and twentieth century. It seems now necessary to focus on another important issue highlighted by historians of recent decades: we refer to the attempt of the dominant groups, in the Liberal and Giolitti era (and later in the fascist one), to affirm a certain «identity and cultural image of childhood» ${ }^{37}$, making it universal, i.e. to constitute a kind of «bourgeois supremacy on childhood», by imposing an ideology / pedagogy of the child

\footnotetext{
${ }^{35}$ For a deeper analysis of these issues see: G. Rossini (ed.), Aspetti della cultura cattolica nell'età di Leone XIII, Roma, Cinque Lune, 1961; S. Lanaro, Società e ideologie nel Veneto rurale (1866-1898), Roma, Edizioni di Storia e Letteratura, 1976; Id., Nazione e lavoro. Saggio sulla cultura borghese in Italia (18701925), Venezia, Marsilio, 1979; Elites e associazioni nell'Italia dell'Ottocento, in "Quaderni Storici», XXVI (1991), n. 2, pp. 357-541; F. Traniello, La cultura popolare cattolica nell'Italia unita, in S. Soldani, G. Turi (edd.), Fare gli italiani. Scuola e cultura nell'Italia contemporanea. I - La nascita dello Stato nazionale, Bologna, Il Mulino, 1993, pp. 429-458; G. Verucci, L'Italia laica prima e dopo l'Unità 1848-1876, RomaBari, Laterza, $1996^{2}$.

${ }^{36}$ See G. Montroni, La famiglia borghese, in P. Melograni (ed. by), La famiglia italiana dall'Ottocento a oggi, Roma-Bari, Laterza, 1988, pp. 107-139. But see also: G. Baglioni, L'ideologia della borghesia industriale nell'Italia liberale, Torino, Einaudi, 1974; and A.M. Banti, Storia della borghesia italiana. L'età liberale, Roma, Donzelli, 1996. For a complete picture of the choices made after the unification by the bourgeois élites see: R. Romanelli, L'Italia liberale 1861-1900, Bologna Il Mulino, 1990, specie le pp. 117 162.

${ }^{37}$ See G. Bonetta, Storia e storiografia alla ricerca delle infanzie reali, in M.C. Giuntella, I. Nardi (edd.), Il bambino nella storia, cit., pp. 40-41.
} 
related to the more general bourgeois objective of cultural hegemony and ideological and political control over society ${ }^{38}$.

A question arises: why the bourgeois model, despite the hegemonic aspirations of the dominant classes, failed, in the nineteenth century, but also in the next century, to become universal, to permeate the customs and educational practices regarding the childhood and to have a decisive impact on the «collective imagination», i.e. on the cultural representations of the child?

The explanation given by Gaetano Bonetta, according to which «the failure of the bourgeoisification, at least from an ideological point of view, of the childhood» would mirror a more general failure of the «political project of a total expansion of the social, economic and political bourgeois type ${ }^{39}$, has certainly its merits, but it does not help much to understand the issue.

To understand the reasons for this failure it is necessary to consider the "places", the tools and the methods through which, especially in the second half of the nineteenth century, the dominant groups tried to impose the «bourgeois rule on childhood», already highlighted by the historiography of the last decades:

- The school, first of all, as a place of transmission of knowledge, but also of certain values and cultural models;

- The children's literature and textbooks, as well as - in terms of the formation of a certain «sentiment of childhood» of the adult world - the great narrative and the "bourgeois novel" of the nineteenth century;

- The pedagogical reflection, especially the scientific-positivist one;

- The new «scientific knowledge» on childhood, which take on a specific social meaning in the Liberal and Giolitti era (pediatrics, child health, developmental psychology, psychoanalysis, etc.);

- The family, as an object of special attention from educators, doctors, writers for children.

The school - It is certainly an already known fact that the school, above all the elementary and popular one, was given by the liberal elites the task of promoting, along with literacy and basic education, the feeling of national belonging and the cultural and civic unification of the populations around certain bourgeois principles and values ${ }^{40}$. Another equally well known fact is that the educational institution did not succeed, at least until the first decades of the twentieth century, to establish itself as a training place that can transmit, in the urban and rural popular classes, the values and the cultural and educational

\footnotetext{
${ }^{38}$ See F. Cambi, S. Ulivieri, Storia dell'infanzia nell'Italia liberale, cit., p. 17 and following.

${ }^{39}$ G. Bonetta, Storia e storiografia alla ricerca delle infanzie reali, cit., p. 41 (but see aldso pp. 44-47).

40 See A. Asor Rosa, Dall'Unità a oggi: la cultura, in R. Romano, C. Vivanti (edd.), Storia d'Italia, Torino, Einaudi, 1975, IV/2, pp. 841 ss.; e and above all the interesting analysis proposed by G. Chiosso, $L a$ questione scolastica in Italia: l'istruzione popolare, in R. Lill, F. Traniello (edd.), Il «Kulturkampf» in Italia e nei paesi di lingua tedesca, Bologna, Il Mulino, 1992, pp. 335-388.
} 
models of the dominant class ${ }^{41}$; i.e. to become the favoured place of that process of «bourgeoisification» of the Italian society Gaetano Bonetta referred to.

And this was due not only to structural problems and deficiencies, as those relating to the insufficient distribution of the chools in the area, to the (sometimes very) low schooling indices and, on the other hand, the high rates of school leaving and evasion from the mandatory education found in many Italian areas (the South, the agricultural and mountainous areas etc.) ${ }^{42}$, but also, and especially, to the gap between the official pedagogy, imposed from above (regulations, programs, ministerial directives etc.), and the real school practice.

The broad survey on the Italian school and teachers' magazines in the nineteenth and twentieth century promoted and coordinated, some decades ago, by Giorgio Chiosso, contributed to the knowledge of the characteristics and dimensions of this gap with original and important elements. As a result, two large catalogues of school and educational magazines in the nineteenth and twentieth centuries and two collections of studies based on the huge archival and printed documents were published ${ }^{43}$. What are the most significant information emerged from this research?

- First of all, the presence of a significant disconnection between the scientificacademic pedagogy and the world of the school (childhood education in kindergartens and elementary and popular education): it is sufficient to refer to the ideas and educational models for childhood proposed in the periodicals for kindergarten teachers or to the educational magazines for elementary teachers ${ }^{44}$;

- Secondly, the prevalence, throughout the nineteenth century, of a localist idea of the school problems and the substantial absence, in the elementary teachers, of a "national" view of their role and function, contributed to the development of the hypothesis - that can be widely shared - of the birth of the "Italian teacher" only at the end of the century ${ }^{45}$.

- Finally, the lack of identification of the elementary teachers with national and patriotic ideals and their substantial non- involvement in the progress of the "bourgeois"

41 See M. Raicich, Scuola e politica da De Sanctis a Gentile, Pisa, Nistri-Lischi, 1982, passim. Sul riemergere, al principio del XX secolo, della questione dell'«educazione nazionale» si veda G. Chiosso, L'educazione nazionale da Giolitti al primo dopoguerra, Brescia, La Scuola, 1983.

${ }^{42}$ See M. Barbagli, Disoccupazione intellettuale e sistema scolastico in Italia (1859-1973), Bologna, Il Mulino, 1974, passim; and the well documented analysis by G. Vigo, Gli italiani alla conquista dell'alfabeto, in S. Soldani, G. Turi (edd.), Fare gli italiani, cit., pp. 37-66.

${ }^{43}$ See G. Chiosso (ed.), I periodici scolastici nell'Italia del secondo Ottocento, Brescia, La Scuola, 1992; G. Chiosso (ed.), Scuola e stampa nel Risorgimento. Giornali e riviste per l'educazione prima dell'Unità, Milano, FrancoAngeli, 1989; G. Chiosso, (ed.), Scuola e stampa nell'Italia liberale. Giornali e riviste per l'educazione dall'Unità a fine secolo, Brescia, La Scuola, 1993; G. Chiosso (ed.), La stampa pedagogica e scolastica in Italia 1820-1943, Brescia, La Scuola, 1997.

${ }^{44}$ See R.S. Di Pol, La stampa per le maestre, in G. Chiosso (ed.), Scuola e stampa nell'Italia liberale, cit., 191-221. A careful analysis on the gap between «the educational and pedagogical culture and the real school», that refers to a longer period compared to the one here considered is presented by R. Fornaca, $L a$ pedagogia e la didattica per la scuola e nella scuola, in G. Cives (ed.), La scuola italiana dall'Unità ai nostri giorni, Firenze, La Nuova Italia, 1990, pp. 323-333.

${ }^{45}$ See G. Chiosso, La questione scolastica in Italia: l'istruzione popolare, cit., specie le pp. 384-388. An important confirmation of this hypothesis can be found in A. Barausse, L'Unione Magistrale Nazionale dalle origini al fascismo (1901-1925), Brescia, La Scuola, 2002. 
culture and science ${ }^{46}$. The same positivist pedagogy - intended to affect the educational practices and educational systems especially from the last decades of the nineteenth century - was accepted in a very partial way by the teachers (think to the lively debate and to the oppositions encountered by Gabelli's Programs in 1888) ${ }^{47}$.

In the light of these results, the hypothesis formulated by Gaetano Bonetta, that the «failure» of the attempt of the liberal ruling class to promote the «ideological expansion of the bourgeois model of childhood» through the school («especially the kindergarten and the elementary compulsory one») would essentially due to the «inconsistency between educational and pedagogical offer and the real demand of childhood education», seems to be suggestive but not sufficiently supported by evidences, especially if we assume the existence of a conscious and well defined «demand for childhood education» by the popular classes.

However, if the school is «the privileged and scientifically appropriate place» for the transmission of the bourgeois model of childhood in the Italian society of the late nineteenth century ${ }^{48}$, it is necessary to consider that a similar process - that a lot of reconstructions of history childhood and its education considered as obvious - was yet to be reached, at least in the nineteenth century.

Children's literature and textbooks - This is a field of research that has to be widely developed, but on which we have already some interesting contributions. It is sufficient to mention the studies by Antonio Faeti and the research group of Bologna, as well as the works by Pino Boero and Carmine De Luca and, more recently, by Renata Lollo, Mariella Colin, Anna Ascenzi, Sabrina Fava and Davide Montino ${ }^{49}$. The valuable and documented

\footnotetext{
${ }^{46}$ On the difficulties in the widespread, among the elementary teachers, of the «political and ideological values that led the National and unitary process» see the important work by G. Verucci, L'Italia laica prima e dopo l'Unità 1848-1876, Roma-Bari, Laterza, 1996², p. 138 and following.; see also: S. Lanaro, Nazione e lavoro. Saggio sulla cultura borghese in Italia 1870-1925, Venezia, Marsilio, 1979. For a comparison on the ideological-political role and function, in the nineteenth century, of the French and German elementary teachers see: J. Ozouf (ed.), Nous, les maîtres d'école. Autobiographies d'instituteurs de la Belle Epoque, Paris, Gallimard, 1967; M. Ozouf, L'école, l'église et la République (1871-1914), Paris, Editions du Seuil, 1982; e A.J. La Vopa, Prussian Schoolteachers: profession and office 1763-1848, Chapel Hill, University of North Carolina Press, 1980.

${ }^{47} \mathrm{See}$, in this sense, G. Chiosso, Giornali e giornalisti per la scuola nel secondo Ottocento, in G. Chiosso (ed.), I periodici scolastici del secondo Ottocento, cit., pp. 40-44. See also R. Fornaca, La scuola italiana e il positivismo, in E.R. Papa (ed.), Il positivismo e la cultura italiana, Milano, Franco Angeli, 1985, pp. 335349. On the kind of reception of the Gabelli's Programs in the real schhols, see the comments contained in magazines such as: «Il Corriere scolastico» (Roma, 1887-1902), «La Guida del maestro elementare italiano» (Torino, 1864-1897), «La Lega degli insegnanti elementari» (Cuneo, 1886-1905), «Il Raccoglitore scolastico» (Trieste, 1893-1895), «Il Rinnovamento scolastico» (Roma, 1892-1899), la «Rivista della Pubblica Istruzione» (Roma, 1887-1911), «La Scuola popolare» (Palermo, 1886-1895). See also E. Catarsi, Storia dei programmi della scuola elementare (1860-1985), cit., p. 43.

${ }^{48}$ G. Bonetta, Storia e storiografia alla ricerca delle infanzie reali, cit., pp. 43-45.

${ }^{49}$ A. Faeti, Guardare le figure, Torino, Einaudi, 1972; Id., Letteratura per l'infanzia, Firenze, La Nuova Italia, 1977; E. Beseghi (ed.), La scala a chiocciola. Paura, horror, finzioni: dal romanzo gotico a Dylan Dog, Scandicci (Firenze), La Nuova Italia, 1993; Ead. (ed.), Infanzia e racconto. Il libro, le figure, la voce, lo sguardo, Bologna, Bononia University Press, 2003 (but see also the series edited by Mondadori «L'isola misteriosa. Quaderni di letteratura per l'infanzia», diretta dalla stessa Emy Beseghi); P. Boero, C. De Luca, Letteratura per l'infanzia, Roma-Bari, Laterza, 1995; P. Boero, Una storia, tante storie. Guida all'opera di Gianni Rodari, Torino, Einaudi, 1992 (new edition: Torino, Einaudi, 2010); Id., Alla frontiera. Momenti, generi e temi della letteratura per l'infanzia, Trieste, Einaudi, 1997; R. Lollo, Sulla letteratura per l'infanzia,
} 
analyses offered by contemporary historians and scholars of literature and culture, such as Alberto Asor Rosa, Guido Verucci, Silvio Lanaro and Antonio Gibelli are also very interesting ${ }^{50}$.

For what concerns the textbooks, in addition to the fundamental, although a little bit old, work by Marcella Bacigalupi and Piero Fossati on the reading books for elementary schools of united Italy ${ }^{51}$, also the important works published over the last two decades by the research group coordinated by Giorgio Chiosso and Roberto Sani have to be mentioned $^{52}$.

Brescia, La Scuola, 2003; Ead. (ed.), Il «Corriere dei piccoli» in un secolo di riviste per ragazzi, Milano, Vita e Pensiero, 2009M. Colin, L'age d'or de la littérature d'enfance et de jeunesse italienne: des origines au fascisme, Caen, Presses Universitaires de Caen, 2005; Ead., "Les enfants de Mussolini». Littérature, livres, lectures d'enfance et de jeunesse. De la Grande Guerre à la chute du régime, Caen, Presses Universitaires de Caen, 2010; A. Ascenzi, La storia della letteratura per l'infanzia oggi. Prospettive metodologiche e itinerari di ricerca, in Ead. (ed.), La letteratura per l'infanzia oggi, Milano, Vita e Pensiero, 2003, pp. 109-120; Ead., «Per educare la gioventù della nuova Italia». Luigi Bertelli giornalista e scrittore per l'infanzia tra eredità risorgimentale e costruzione di una nuova coscienza etico-civile (1860-1920), in A. Ascenzi, M. Di Felice, R. Tumino (ed by), "Santa Giovinezza!». Lettere di Luigi Bertelli e dei suoi corrispondenti (1883-1920), Macerata, Alfabetica Edizioni, 2008, pp. 13-43; Ead., Il Plutarco delle donne. Repertorio della pubblicistica educativa e scolastica e della letteratura amena destinata al mondo femminile nell'Italia dell'Ottocento, Macerata, EUM, 2009; S. Fava, Emilia Formíggini Santamaria. Dagli studi storico-pedagogici alla letteratura per l'infanzia, Brescia, La Scuola, 2002; Ead., Dal "Corriere dei Piccoli». Giana Anguissola scrittrice per ragazzi, Milano, Vita e Pensiero, 2009; D. Montino, Libri e giovani lettori tra XIX e XX secolo: un percorso di tipo qualitativo, «History of Education \& Children's Literature», II (2007), 1, pp. 299-322; Id., Le tre Italie di Giuseppe Fanciulli. Educazione e letteratura infantile nel primo Novecento, Torino, SEI, 2009; Id., Giuseppe Fanciulli negli anni de "Il Giornalino della Domenica». Infanzia, giornalismo e politica, «History of Education \& Children's Literature», VI (2011), 1, pp. 305-317; e Id., Società, infanzia e narrazioni realistiche nella letteratura giovanile dell'Italia del secondo dopoguerra (1946-1962), «History of Education \& Children's Literature», VII (2012), 2, pp. 287-318.

${ }^{50}$ A. Asor Rosa, Dall'Unità a oggi: la cultura, in R. Romano, C. Vivanti (edd.), Storia d'Italia, Torino, Einaudi, 1975, IV/2, pp. 822-1311; G. Verucci, L'Italia laica prima e dopo l'Unità 1848-1876, cit., pp. 65178; S. Lanaro, Il Plutarco italiano: l'istruzione del "popolo" dopo l'Unità, in C. Vivanti (ed.), Storia d'Italia. Annali 4: Intellettuali e potere, Torino, Einaudi, 1981, pp. 553-587; Id., Nazione e lavoro. Saggio sulla cultura borghese in Italia 1870-1925, cit.; A. Gibelli, Il popolo bambino. Infanzia e nazione dalla Grande Guerra a Salò, Torino, Einaudi, 2005.

${ }^{51}$ M. Bacigalupi, P. Fossati, Da plebe a popolo. L'educazione popolare nei libri di scuola dall'Unità d'Italia alla repubblica, Firenze, La Nuova Italia, 1986.

${ }_{52}$ G. Chiosso, Editoria e stampa scolastica tra Otto e Novecento, in L. Pazzaglia (ed.), Cattolici, educazione e trasformazioni socio-culturali in Italia tra Otto e Novecento, Brescia, La Scuola, 1999, pp. 499527; Id. (ed.), Il libro per la scuola tra Sette e Ottocento, Brescia, La Scuola, 2000; Id. (ed.), TESEO. Tipografi e editori scolastico-educativi dell'Ottocento, Milano, Editrice Bibliografica, 2003; Id., L'editoria scolastica prima e dopo la riforma Gentile, «Contemporanea», 7 (2004), 3, pp. 411-434; Id., Il rinnovamento del libro scolastico nelle esperienze di Giuseppe Lombardo Radice e dei «lombardiani», «History of Education \& Children's Literature», I (2006), 1, pp. 127-139; Id. (ed.), TESEO '900. Editori scolasticoeducativi del primo Novecento, Milano, Editrice Bibliografica, 2008; A. Ascenzi, R. Sani (edd.), Il libro per la scuola tra idealismo e fascismo. L'opera della Commissione centrale per l'esame dei libri di testo da Giuseppe Lombardo Radice ad Alessandro Melchiori (1923-1928), Milano, Vita e Pensiero, 2005 ; A. Barausse, L'editoria scolastico-educativa nell'Italia Meridionale del primo Novecento: il caso del Molise (1900-1943), in Tipografia e editoria in Abruzzo e Molise. Il XX secolo, Soveria Mannelli, Rubbettino, 2007, pp. 211-261; F. Targhetta, La capitale dell'impero di carta. Editori per la scuola a Torino nella prima metà del Novecento, Torino, SEI, 2007; Id., Serenant e illuminant. I cento anni della SEI, Torino, SEI, 2008 ; A. Barausse (ed.), Il libro per la scuola dall'Unità al fascismo. La normativa sui libri di testo dalla legge Casati alla riforma Gentile (1861-1922), Macerata, Alfabetica Edizioni, 2008, 2 voll.; M. D’Alessio, Scuola e lingua nel Molise di fine Ottocento, Napoli, Edizioni Scientifiche Italiane, 2005; A. Ascenzi, R. Sani (edd.), Il libro per la scuola nel ventennio fascista. La normativa sui libri di testo dalla riforma Gentile alla fine 
These and other studies, on which we can not dwell on, clearly reveal the peculiar function of such publications in transmitting/conveying values, lifestyles, address and educational models, the same «imaginary» on childhood, characteristic of the dominant bourgeois classes. «For what concerns Italy - Franco Cambi pointed out- it is not a coincidence that this type of literature flourished precisely in the nineteenth century, $[. .$. especially in the second half of the century, exactly when the bourgeois class (even if with delays and lacks) was developing, with a clear governmental intention, in every direction, from the political to the private» ${ }^{53}$.

However, the basic impression is that, beyond its intrinsic value, the spread of such publications was, at least until the end of the century, much more limited and circumscribed than one, at a first glance, would assume. Keeping in mind the miserable conditions of popular education in rural areas ${ }^{54}$ and the objective difficulties, even after the Coppino Law (1877), in the spread of literacy processes and primary education in the countryside and in many parts of central and Southern Italy ${ }^{55}$, we can affirm that the circulation of textbooks and of the literature for children and youth affected the urban centers and the most literate areas of the peninsula as well as the upper classes and upper levels of the artisan and working population ${ }^{56}$.

della seconda guerra mondiale (1923-1945), Macerata, Alfabetica Edizioni, 2009; A. Barausse, Dal Regno di Sardegna al Regno d'Italia. Continuità e discontinuità nelle politiche del libro scolastico, «History of Education \& Children's Literature», V (2010), 1, pp. 377-415; V (2010), 2, pp. 301-338; A. Ascenzi, «Per impedire l'intrusione nell 'istruzione nazionale del seme di mala scienza e di mali costumi». La relazione di Luigi Gabriele Pessina sull'esame dei libri di testo (1881), «History of Education \& Children's Literature», V (2010), 2, pp. 339-381; M.C. Morandini, I manuali per l'educazione dei sordomuti: $i$ testi di lingua e di istruzione religiosa, in P. Bianchini (ed. by), Le origini delle materie. Discipline, programmi e manuali scolastici in Italia, Torino, SEI, 2010, pp. 139-165; D. Montino, La storia nei libri scolastici elementari del dopoguerra, ivi, pp. 217-246; the contributions on school publishing industry and on textbooks collected in R. Sani, Sub specie educationis. Studi e ricerche su istruzione, istituzioni scolastiche e processi culturali e formativi nell'Italia contemporanea, Macerata, EUM, 2011; and the recent G. Chiosso, Libri di scuola e mercato editoriale. Dal primo Ottocento alla Riforma Gentile, Milano, Franco Angeli, 2013.

${ }^{53}$ F. Cambi, S. Ulivieri, Storia dell'infanzia nell'Italia liberale, cit., p. 28.

54 See T. Tomasi, Da Matteucci a Corradini. Le inchieste sulla scuola popolare nell'età liberale, in C.I.R.S.E., Problemi e momenti di storia della scuola e dell'educazione, Pisa, ETS, 1982, pp. 117-143, which, based on the results of ministerial investigations, points out that: «Not even the 1868-1872 investigation gives encouraging results regarding the students' advancements; everywhere, although with considerable differences between north and south, urban and rural, it is very low, due to the number of pupils, the totally unsuitable places, the absence and lack of the essential educational tools, starting from the books. [...]in the South the difficulties are even worst: here, primary education, considered a class privilege, continued to remain alien to the 'miserable plebs'. [...] According to the Ravà investigation (1897-1898), which also includes contents and methods, [...] a genuine renewal is always hindered [...] by the poverty of teaching aids» (pp. 136-137).

${ }^{55} \mathrm{See}$, in this sense, G. Talamo, Istruzione obbligatoria ed estensione del suffragio, in Stato e società dal 1876 al 1882. Atti del XLIX Congresso di Storia del Risorgimento Italiano, Roma, Istituto per la Storia del Risorgimento Italiano, 1980, pp. 57-110; e G. Vigo, "Quando il popolo cominciò a leggere». Per una storia dell'alfabetismo in Italia, in «Società e Storia», VI (1983), n. 22, pp. 803-828.

${ }^{56}$ On the spread of the reading practice in the urban popular classes in the late nineteenth century see: S. Pivato, Movimento operaio e istruzione popolare nell'Italia liberale. Discussioni e ricerche, Milano, Franco Angeli, 1986, pp. 17-88; G. Barone, A. Petrucci, Primo: non leggere. Biblioteche e pubblica lettura in Italia dal 1861 ai nostri giorni, Milano, Mazzotta, 1976, pp. 33-49. On the role played in this field by the labouring societies Of mutual aids and by the leagues for popular education see:, G. Verucci, L'Italia laica prima e dopo l'Unità 1848-1876, cit., pp. 81-112. 
This hypothesis seems to find a partial confirmation in the repeated complaints about the lack of good books specifically aimed at children and poor youth of the rural areas, especially in the seventies and eighties of the nineteenth century, by philanthropic educators and associations engaged in popular education ${ }^{57}$.

The new «scientific knowledge» on childhood - In the wake of Michel Foucault's fundamental studies on the relationship between science, dominant ideologies and social control $^{58}$, as well as of recent studies started in Italy on the evolution of medicine and humanities in the second mid-nineteenth century ${ }^{59}$, the historical and pedagogical research has devoted increasing attention to the role played by the new «scientific knowledge» in the determination/ dissemination of specific forms of body control and of regulation of the attitudes and behaviors of children based on the principles of ethics and of the dominant bourgeois ideology.

The enhancement of gymnastics (think, for example, to the lively debate developed on the significance and objectives of physical education at school) ${ }^{60}$, the importance given to the hygiene in the educational theory and practice, the development of a real childhood medicalization, with the consequent redefinition of childhood pedagogy as clinical physical and psychological development of the child ${ }^{61}$, represent the different aspects of the process determining what Franco Cambi called «a specific frontier of the bourgeois rule on childhood» ${ }^{62}$.

Again, however, one gets the impression that the so-called «bourgeois science», whose expansion and circulation had to be provided by the decisive contribution of the

57 This situation, for example, was repeatedly emphasized by Ottavio Gigli, secretary of the National Association of Rural Kindergarten for Children, an association founded in Florence in 1866 to promote childhood and popular education in the countryside, and which include among its promoters Niccolò Tommaseo, Gino Capponi, Bettino Ricasoli, Carlo Matteucci, who was its first president, and Terenzio Mamiani, who assumed the presidency after the death of Matteucci. See in this respectA. Ascenzi, R. Sani, "Moulding the peasant masses to make our Italy into a Nation». Ottavio Gigli and the National Association for the Founding of Rural Infant Schools, from the struggle against illiteracy to nation-building (1866-1873), in «History of Education \& Children's Literature», VIII (2013), n. 2, pp. 159-194; IX (2014), n. 1, pp. 388450.

${ }^{58}$ See, in particolar, M. Foucault, Le parole e le cose. Un'archeologia delle scienze umane, it. translation, Milano, Rizzoli, 1967; Id., Nascita della clinica. Il ruolo della medicina nella costituzione delle scienze umane, it. translation, Torino, Einaudi, 1969; Id., Sorvegliare e punire. La nascita della prigione, it. translation, Torino, Einaudi, 1976.

${ }^{59}$ See, above all, G. Cosmacini, Medicina, ideologia, filosofia nel pensiero dei clinici, in C. Vivanti (ed.), Storia d'Italia Annali, 4. Intellettuali e potere, Torino, Einaudi, 1981; Id., Storia della medicina e della sanità in Italia, Roma-Bari, Laterza, 1987; R. Viale, Medicina e positivismo, in E.R. Papa (ed.), Il positivismo e la cultura italiana, cit., pp. 412 ss.; e i diversi contributi pubblicati in F. Della Peruta (ed.), Storia d'Italia, Annali, 7. Malattia e medicina, Torino, Einaudi, 1984.

${ }^{60}$ On this topic, see: G. Bonetta, Corpo e nazione. L'educazione ginnastica, igienica e sessuale nell'Italia liberale, Milano, Franco Angeli, 1990.

${ }^{61}$ «All in all - Egle Becchi wrote a few years ago - the children's body is the great center, positive and negative, of the childhood story in the nineteenth century. A nice and neglected body, but also and especially a "straightened body", a fine body, but also disciplined up to the mortification, a trained body, grown with care and support. We have to remember, in fact, - included in a pedagogy typical of the nineteenth-century, which is mainly orthopedics - all the prostheses that help the child's physicality» (E. Becchi, L'Ottocento, in E. Becchi, D. Julia (a cura di), Storia dell'infanzia. 2. Dal Settecento a oggi, cit., p. 153).

${ }^{62}$ F. Cambi, S. Ulivieri, Storia dell'infanzia nell'Italia liberale, cit., p. 9. But see, in particolar, Cambi's observations in the chapter II: «I medici-igienisti e l'infanzia: controllo del corpo e ideologia borghese» (ivi, pp. 53-80). 
school63 and of popular publications (but destined to find its main representatives in the bourgeois class and in the upper levels of the industrial proletariat of the large urban centers) specifically dedicated to science ${ }^{64}$, has failed, at least throughout the nineteenth century, to become «a mass knowledge» that had a genuine and systematic influence on the mentality, customs, on the individual and collective "experience" of the poor urban class and, in particular, of rural populations.

It is necessary to identify what "different" or "alternative" knowledge, models, ideas of childhood and of its education, compared to the dominant bourgeois ones, have actually influenced the behaviors and practices in relation to the different childhoods in Italy in the nineteenth century and in the first decades of the current century.

The family - The family is an important area of analysis and verification for the historian of childhood and of its education, but is an undoubtedly difficult reality to be studied, especially in terms of strategies and training practices ${ }^{65}$, that are, in fact, almost completely ignored despite the valuable historical and social studies during recent decades ${ }^{66}$.

First of all, there is a problem of sources ${ }^{67}$, but there is also the need to develop new methods of investigation, specific interpretive guidelines capable of penetrating a cultural and social universe that still appears, in many aspects, elusive.

The three models identified by sociological research, and adopted by several historians of childhood- that are the «bourgeois family», the «urban popular workingclass» one, and the «peasant» one- are of little help and provide the historians with so general references to become almost generic. Certainly, it is perfectly evident that they are very different realities, with extremely different material conditions of life, forms of

${ }^{63}$ Ibidem, pp. 61-66.

${ }^{64}$ As an example, we remember the series by the publishing house Sonzogno: «Biblioteca del popolo» (from 1873), «L'igiene popolare» and «Biblioteca Universale» (dal 1882); and the ones by Treves: «Biblioteca utile» (from1864) and «La Scienza del Popolo» (from 1867). Also consider the various similar works appeared in non-specific book series by different publishing houses (U.T.E.T., Barbèra, Sandron ecc.) and in particular, the ones, published in the famous Manuali Hoepli.Among the periodicals: «L'Igea. Giornale d'igiene e medicina preventiva» (Milano, dal 1862), «La salute. Giornale d'igiene popolare» (Genova, dal 1864), «Igiene infantile» (Venezia, dal 1878), «L'igiene dell'infanzia e medicina preventiva» (Roma, dal 1892), «Igiene e Scuola» (Mantova, dal 1892).

${ }^{65}$ See R. Sani, For a History of Family Education in the Modern and Contemporary Era. Research Itineraries and Perspectives, in «History of Education \& Children's Literature», I (2006), n. 1, pp. 55-81.

${ }^{66}$ With reference to the Italian reality, see: M. Barbagli, Sotto lo stesso tetto. Mutamenti della famiglia in Italia dal XV al XX secolo, Bologna, Il Mulino, 1984; Id., Provando e riprovando. Matrimonio, famiglia e divorzio in Italia e in altri paesi occidentali, Bologna, Il Mulino, 1990; P. Melograni (ed.), La famiglia italiana dall'Ottocento a oggi, Roma-Bari, Laterza, 1988; M. Barbagli, D.I. Kertzer (edd.), Storia della famiglia italiana 1750-1950, Bologna, Il Mulino, 1992; G. Campanini (ed.), Le stagioni della famiglia. La vita quotidiana nella storia d'Italia dall'unità agli anni Settanta, Cinisello Balsamo (Milano), San Paolo, 1994. For what concerns the European and extra-european context, see: C.E. Rosemberg (ed.), The Family in History, Philadelphia, The University of Pennsylvania Press. Inc., 1975; E. Shorter, The Making of the Modern Family, New York, Basic Book, 1975; M. Anderson, Approaches to the History of the Western Family 1500-1914, London, 1980; J. Goody, The Development of the Family and Marriage in Europe, Cambridge, Cambridge University Press, 1983; R. Wall, J. Robin, P. Laslett (edd.), Family Forms in Historic Europe, Cambridge, Cambridge University Press, 1983; F. Lebrun, La vie coniugale sous l'Ancien Régime, Paris, A. Colin, 1993.

${ }^{67}$ See G. Campanini, La storiografia della famiglia in Italia: Bilancio, problemi, prospettive, in Id. (ed.), Le stagioni della famiglia. La vita quotidiana nella storia d'Italia dall'unità agli anni Settanta, cit., pp. 15-37. 
socialization, but also of «collective imagination» and ideal frameworks. But this is not enough. The same «bourgeois» family i.e. the one we know- or believe to know - better, presents many aspects and differentiations when analysed in a more careful and detailed way $^{68}$.

Just one example: the bourgeoisie in Veneto after the unification is linked to a culturally and politically conservative Catholicism, which, as the studies by Gabriele De Rosa, Angelo Gambasin and Silvio Lanaro have shown ${ }^{69}$, is organized around the parish. So, it is animated by a strong anti-liberal and anti-statist feeling and is linked to religious values and to its rural roots, but at the same time, it shows interest in the innovation and development in the economic and productive field: it can be defined, so, as a very different reality compared to the other bourgeoisies of the peninsula.

Now, the point is: did its "imagination" on childhood, its conception of children and their care and education, its training practices coincide with those promoted by the positivistic scientific and pedagogical literature? This is an issue to be verified. But this same discourse could also be extended to other areas and to other social groups.

Speaking about the «peasant» family ${ }^{70}$, we have the impression that if you really want to understand such a complex and characteristic situation, it is necessary that the historians of childhood expand the general cultural references. It seems astonishing, for example, the fact that the few scholars who have studied peasant childhood in Italy in the nineteenth and twentieth century have referred, exclusively or almost exclusively, to the studies by Ernesto De Martino, Vittorio Lanternari, Luigi M. Lombardi Satriani and others, i.e. to anthropological and ethnological research, investigations on folklore, totally ignoring the fundamental - and, we think, essential - contribution given by the social and religious historiography to the knowledge of the rural reality of the last two centuries in our country ${ }^{71}$.

68 «The real situation - Giovanni Montroni noted, of the "bourgeois family" in Italy in the nineteenth century - is more complex. [...] And it is even difficult to talk about, also not considering the entrepreneurial bourgeoisie, of a real bourgeois family. It seems necessary to distinguish a series of bourgeois levels and functions and a corresponding series of structures and domestic relations, always remembering that regional differences and the relationships with the world of agriculture contribute to further multiply the prevailing family systems. We don't know anything, despite the unanimous recognition of their importance, of the lower middle classes or, as they are called today, of the numerous bourgeoisies » (G. Montroni, La famiglia borghese, in P. Melograni (ed.), La famiglia italiana dall'Ottocento a oggi, cit. p. 112).

69 See G. De Rosa, Mentalità e mutamenti economici nella società veneta, in A. Lazzarini (ed.), Trasformazioni economiche e sociali nel veneto fra XIX e XX secolo, Vicenza, Istituto per le ricerche di storia sociale e di storia religiosa, 1984, pp. 13-36; G. Gambasin, Mentalità parrocchiale e centri urbani nel Veneto alla fine dell'Ottocento, in «Ricerche di storia sociale e religiosa», I (1972), n. 2, pp. 131-182; S. Lanaro, Movimento cattolico e sviluppo capitalistico nel Veneto fra '800 e' '900. Linee interpretative, in Movimento cattolico e sviluppo capitalistico, in «Studi Storici», XV (1974), n. 1, pp. 11-51.

${ }^{70}$ It perhaps it would be more appropriate to talk about different types of families of peasants and agricultural society as a whole. See M. Barbagli, Sotto lo stesso tetto. Mutamenti della famiglia in Italia dal $X V$ al XX secolo, cit., pp. 525-538.

${ }^{71}$ As an example, we remember: G. De Rosa, Vescovi, popolo e magia nel sud. Ricerche di storia socioreligiosa dal XVII al XIX secolo, Napoli, Guida, 1971; Id., Chiesa e religione popolare nel Mezzogiorno, Roma-Bari, Laterza, 1978; S. Lanaro, Società e ideologia nel Veneto rurale (1866-1898), Roma, Edizioni di Storia e Letteratura, 1976; A. Cestaro, Strutture ecclesiastiche e società nel Mezzogiorno, Napoli, Ferraro, 1978; A. Gambasin, Parroci e contadini nel Veneto alla fine dell'Ottocento, Roma, Edizioni di Storia e Letteratura, 1973; G. Rosoli (ed.), Chiesa ed emigrazione italiana tra '800 e '900, Roma, C.S.E.R., 1982; La 
The countryside- in the north and, with different modalities and rhythms, in the Centre-South - saw the development, in the late nineteenth century, of a strong and rooted Catholic social movement, organised around the bishops and parish priests: a movement based on the values of solidarity and cooperation of the Christian social doctrine, and that was involved in an extensive economic and social modernization process and in the growth of a wider civic and cultural sensitivity among the rural populations. It is sufficient to recall the network of mutual aid societies, cooperatives of workers, rural banks, charitable and educational institutions which found their reference point in the parish ${ }^{72}$.

In this context the Church had a deep impact and an anti-bourgeois function (think to the influence of the Catholic intransigency), promoting an ethical-religious sensitivity and a very different vision of man and society, compared to those which inspired the bourgeois elites of the great urban centers ${ }^{73}$.

It is necessary to deeply analyse - and this is a research largely to be done - how much the strong presence of the Church in the different agricultural areas of our country has influenced the models and educational practices for children.

\section{For an expansion of the historical survey on childhood and its education in Italy between the nineteenth and twentieth centuries: sources and research perspectives}

The above stated comments and considerations raise two undoubtedly important issues for a more accurate historical research on childhood and its education in Italy in the nineteenth and twentieth century.

First of all, the need for an expansion of sources and documentary materials on which base the research activity, as well as a more comprehensive and systematic use of already-known sources, only partially used. This is the case, for example, of children's literature and textbooks for the elementary school: a survey on these valuable printed materials can not be limited to a textual analysis (content, models, training orientations) but must necessarily be extended to issues of considerable importance for the historian of childhood, such as the spread (print run, reprints etc.) and the actual circulation of texts in different social and cultural contexts, by checking, for example, the catalogues of school and public libraries, of the circulating rural ones, of the lists of works acquired by the Society of mutual aid and the leagues for popular education ${ }^{74}$.

società religiosa nell'età moderna Atti del Convegno Studi di storia sociale e religiosa (Capaccio-Paestum, 18-21 maggio 1972), Napoli, Guida, 1973. On the orientations of the Italian socio-religious historiography see in particular: A. Lazzarini, Studi di storia socio-religiosa, in «Quaderni Storici», IX (1974), n. 26, pp. 568-581; e F. Salimbeni, Problemi e prospettive di storia socio-religiosa, in A. Cestaro (ed.), Studi di storia sociale e religiosa. Scritti in onore di Gabriele De Rosa, Napoli, Ferraro, 1980, pp. 155-177.

72 See Archivio per la Storia del Movimento Sociale Cattolico in Italia, Mezzo secolo di ricerca storiografica sul movimento cattolico in Italia. Dal 1861 al 1945: contributo a una bibliografia, Brescia, La Scuola, 1995 (in particular the introductive essay by A. Canavero, pp. 7-72).

73 See, in this respect, the interesting considerations by F. Traniello, La cultura popolare cattolica nell'Italia unita, in S. Soldani, G. Turi (edd.), Fare gli italiani, cit., pp. 429-458.

${ }^{74}$ See A. Ascenzi, Children's literature as a "source" for the history of education and cultural processes. Toward an on-going assessment of studies conducted in Italy over last decade, in «History of Education \& Children's Literature», VII (2012), n. 2, pp. 79-96; Ead., La ricerca sulla manualistica scolastica in Italia: nuovi orientamenti storiografici e prospettive per il futuro, in J. Meda, A.M. Badanelli (edd.), La historia de la cultura escolar en Italia y en España: balance y perspectivas, Macerata, EUM, 2013, pp. 119-138. 
The other issue concerns the need for a further, more serious and systematic analysis of the role played by the Church in Italy in the nineteenth and twentieth century both in the creation of a new "idea" of childhood, and in the field of welfare and educational initiatives specifically aimed at the world of childhood.

\section{1 - Sources}

a) A source still almost completely ignored, at least in our country, by the historian of education and childhood is represented by the minor essays devoted to family: we refer to the great number of essays, pamphlets, and other popular writings for fathers and mothers focused on issues of family life and education. They are unpretentious publications, whose authors were pastors, priests, religious men, more rarely members of the Catholic secular world, and addressed to a very diverse audience of readers (peasants, artisans, employees, merchant). They provide practical / operational suggestions about the most appropriate way to raise and educate children, to promote and preserve the harmony of the family unit, to guide their sons in relation to Christian life and religious practice, the studies, the behavior in society, the work and the occupational choices ${ }^{75}$.

A first, partial census of these publications, carried out by a working group coordinated by the writer of this article, has identified, in relation to the nineteenth century, more than 500 works related to this genre ${ }^{76}$. These essays, written in a plain language, with a modest letterpress and editorial format and with a very little cost, experienced a growing popularity after the unification and at least until the First World War, as evidenced by the frequent reprints and new editions (some of them recorded up to half a dozen of editions within sixty years).

Two aspects of this minor publications deserve to be mentioned: the conspicuous presence of texts devoted to rural families and generally wrote by country priests 77 , and the prevailing presence, among the publishers and/or printers of Catholic publishing houses

\footnotetext{
${ }^{75}$ As an example, see: S. Brigidi, L'educazione in famiglia, Firenze, Tip. Galileiana, 1867; Ammonimenti alle fanciulle cristiane, Milano, Tip. e Libreria Arcivescovile, 1870; La buona madre di famiglia, Torino, Tip. De Agostini, 1871²; G. Belluomini, Manuale delle madri cristiane, Siena, La Madre Cristiana, 1874; C. Calandrelli, L'istitutore novello in famiglia, Roma, Tip. Editrice Romana, 1877; C. Allario, Manuale delle madri di famiglia, Torino, Paravia, 1878; L.-E.-M. Bautain, La paternità cristiana. Istruzioni ad un padre, traduzione del sac. Francesco Bricolo, Treviso, Tip. Istituto Turazza, 1888; J.-J. Berthier, La madre secondo il cuore di Dio, ossia doveri della madre cristiana, Torino, Tip. Salesiana, 1890; Avvertenze, massime e riflessioni alla gioventù ed ai genitori... di un pio sacerdote, Ivrea, Tip. A. Tomatis, 1892; M. Bianchini, Guida alle madri cattoliche, Brescia, Tip. Queriniana, 1899.

${ }^{76}$ In the «Centro di documentazione e ricerca sulla storia del libro scolastico e della letteratura per l'infanzia» of the University of Macerata, the author of this article and Anna Ascenzi are preparing a repertoire of printed sources and publications specifically devoted to family education, published in Italy from the sixteenth to the nineteenth century. On this issue, considerable ideas are also contained in A. Ascenzi, Il Plutarco delle donne. Repertorio della pubblicistica educativa e scolastica e della letteratura amena destinate al mondo femminile nell'Italia dell'Ottocento, Macerata, EUM, 2009.

${ }^{77} \mathrm{See}$, for example, il Calendario delle madri cristiane, Lodi, Tip. vescovile, 1898, 2 voll. (published in the series «Piccola biblioteca dei curati di campagna»).
} 
or Episcopal typographies or belonging to religious institutions (Salesians, Scolopi, Jesuits etc. $)^{78}$.

b) For what concerns the transmission of models, teaching styles, educational practices intended for children and youth, the so-called «devotional literature» is full of important ideas and directions. It is, again, a type of publications still little studied by the historians of education and childhood, and on which a scholar of spirituality, Annarosa Dordoni focused her attention a few years ago, in an important essay published in the «Annali di storia dell'educazione e delle istituzioni scolastiche» ${ }^{79}$.

The «devotional literature» was addressed to all the levels of population and characterized, also in the eight and nineteenth centuries, by a wide diffusion ${ }^{80}$, having parishes and religious institutions as its special places of circulation. For the purposes of our discussion, it is worth noticing that it is characterized not only for its purpose of spiritual edification and guidance to the exercise of the devout practices, but also for its specific educational purpose, i.e. as a privileged instrument for the transmission of patterns of behavior consistent with the Christian faith. "The manuals of devotion - as it was effectively stressed - thus become the means of transmission of religious values and ethical principles, aimed not only to guide and strengthen the piety of individual believers, but also to influence and shape social behaviours. Rules and norms of life [...] are presented as short codes of conduct[...] where Christian principles and normative models of social life are often intertwined» ${ }^{81}$.

c) A peculiar trend of devotional literature is that of «popular hagiographies». Consider, in particular, the so-called Lives of the Saints, a kind of publications addressed primarily for the lower levels of the population with the purpose of Christian edification. The Lives of the Saints spread since ancient times and, after the Council of Trent, experienced a new and wider diffusion, with the aim to spread Christianity among the popular classes and to renew habits and models of religious life of the Church in the

78 The presence of works printed by Salesian Tip. of Turin and the Queriniana Tip. of Brescia are particularly important, especially in the second half of the nineteenth century.

79 See A. Dordoni, I libri di devozione dell'Ottocento (con particolare riferimento alla produzione milanese): proposte per una lettura critica, «Annali di storia dell'educazione e delle istituzioni scolastiche», I (1994), pp. 59-102; and Ead., I libri di devozione nell'800: una lettura critica, in Chiesa e società a Bergamo nell'Ottocento, Milano, Glossa, 1998, pp. 203-234.

${ }^{80}$ A. Dordoni, I libri di devozione dell'Ottocento (con particolare riferimento alla produzione milanese): proposte per una lettura critica, cit., pp. 92-93. Si veda inoltre P. Stella, Produzione libraria religiosa e versioni della Bibbia in Italia tra età dei lumi e crisi modernista, in M. Rosa (ed.), Cattolicesimo e lumi nel Settecento italiano, Roma, Herder, 1981, pp. 99-125. For the first years of the twentieth century see also the results of the survey promoted in 1905 by the Società bibliografica italiana: I libri più letti dal popolo italiano. Primi risultati dell'inchiesta promossa dalla Società bibliografica italiana, Milano, Società Bibliografica Italiana, 1906.

${ }^{81}$ A. Dordoni, I libri di devozione dell'Ottocento (con particolare riferimento alla produzione milanese): proposte per una lettura critica, cit., p. 85. But see also: M. Marcocchi, Le dimensioni educative nella letteratura di pietà, in L. Pazzaglia (ed.), Cattolici, educazione e trasformazioni socio-culturali in Italia tra Otto e Novecento, Brescia, La Scuola, 1999, pp. 189-209; and R. Sani, Educational and mass market Catholic publishing in Italy between the two wars, in in «History of Education \& Children's Literature», II (2007), n. 2, pp. 217-238. 
confessional age ${ }^{82}$. After the revolutionary experience (during which, among other things, such hagiographies contrasted with secular and popular publications aimed at the celebration of «counter-models» such as the so-called «martyrs of freedom and revolution ${ }^{83}$ ), and throughout the nineteenth century, the Lives of the Saints enjoyed a renewed fortune and their circulation affected all the strata of the population, both urban and rural.

They are, again, simple works written in a plain language and full of references to the catechism and the everyday devout practice, aimed to strike feelings and imagination, more than reason. For the purposes of our discussion, it is worth noticing that those hagiographies were read by the youth from the various social classes not only for "pleasure" and "moral edification" (as they were presented by the parish priests, confessors etc.), but that, since the end of the sixteenth century and until the mid- twentieth, they formed - together with the spelling book, catechism and abacus - the more prevalent "textbooks" in male and female popular schools directed by the clergy and religious class, as well as by private secular teachers, in the pre-unification Italian states84. For centuries, then, the Lives of the Saints have been a major literacy tool for the transmission of moral contents and educational ideals and models.

But there's more: this source is particularly significant as it reflects a peculiar formative purpose. The Lives of the Saints, in fact, were written and used at different levels (by teachers, pastors, parents) with the main purpose to provide the reader with ideals and patterns of behaviour, ethical principles, tips and suggestions about how to operate in life. It should also be noted that the sacred writer builds the Life of the Saint following a typical model, with a narrative structure that obeys precise stereotypes: the exercise of human and Christian virtues, religious practice, public behaviour, the relationship with the body, the attitude towards illness, misfortune, daily difficulties; the choices of life and on the future and so on. The systematic and conventional repetition of these aspects in all the hagiographies allows, for example, to analyze the long-term evolution of certain ideals and educational models, as well as their greater or lesser impact on the training customs and practices.

In this context, the space (sometimes, as in the Lives of the Saints published in the nineteenth century, very substantial) given in popular hagiographies to the narration of the saint's childhood and youth, i.e to the «saint as a child» ${ }^{85}$ is particularly important. Here, the purpose of providing a childhood behaviour pattern becomes evident and the repetitive

${ }^{82}$ See, in this sense, S. Gajano Boesch, L. Sebastiani (edd.), Culto dei santi, istituzioni e classi sociali in età preindustriale, L’Aquila, Japadre, 1984; S. Gajano Boesch (ed.), Raccolte di vite dei santi dal XIII al XVIII secolo. Strutture, messaggi, fruizioni, Fasano, Schena, 1990; S. Gajano Boesch, L. Scaraffia (edd.), Luoghi sacri e spazi della santità, Torino, Rosenberg \& Sellier, 1990; G. Barone, M. Caffiero, F. Scorza Barcellona (ed. by), Modelli di comportamento e modelli di santità. Contrasti, intersezioni, complementarità, Torino, Rosenberg \& Sellier, 1994.

${ }^{83}$ See C. Langlois, Les martyrs de la liberté comme contre-modèl, in G. Barone, M. Caffiero, F. Scorza Barcellona (edd.), Modelli di comportamento e modelli di santità, cit., pp. 415-429; e T. Tackett, La Révolution, l'Eglise, la France, Paris, Editions du Cerf, 1986, pp. 268-282.

${ }^{84}$ In this respect, see: R. Sani, "Ad Maiorem Dei Gloriam». Istituti religiosi, educazione e scuola nell'Italia moderna e contemporanea, Macerata, E.U.M., 2009.

${ }^{85}$ SeeA. Benvenuti Papi, E. Giannarelli (edd.), Bambini santi. Rappresentazioni dell'infanzia e modelli agiografici, Torino, Rosenberg \& Sellier, 1991, che però dedica scarsissima attenzione ai secoli XIX e XX. 
and conventional character of the hagiographic narratives enables the historian to verify the persistence and / or changes during the time of some of the characteristics of the educational ideal for the childhood ${ }^{86}$.

Finally, we can affirm that a source as the Lives of the Saints, for its characteristics, can be also used to highlight the long-term evolution of the idea of the child and the more general meaning given to children by the adult world ${ }^{87}$.

\subsection{Research Perspectives}

The detailed study of the role played by the Church in the care and infant education sector in Italy between the nineteenth and twentieth centuries implies, first of all, the beginning of systematic investigations on the different institutions and experiences of religious animation and catechesis promoted at a diocesan and parish level and addressed primarily to children and youth.

Consider, for example, the vast and complex network of parish oratories, of Sunday schools of catechism, of prayer groups; as well as the Marian Congregations (especially those named after St. Aloysius Gonzaga and addressed to the youth of both sexes) and, later, the local sections of the male and female youth of the Catholic Action.

They were institutions and initiatives that have had a significant impact at an educational level, but on which we have not organic studies to fully assess the type of proposal and training models, the impact at the local and national level, the institutional development and that of the educational programs and guidelines in the long term ${ }^{88}$.

The research on this side could use the rich documentation, still mostly unexplored, preserved in the diocesan archives and, sometimes, in the individual parishes (for the period closest to us), as well as the rich collection of printed materials, bulletins, periodicals at local and national levels promoted by the coordinating bodies of these initiatives (it is the case, for example, of the oratories, the Marian congregations and Catholic action groups).

${ }^{86}$ See G. Barone, M. Caffiero, F. Scorza Barcellona (edd.), Modelli di comportamento e modelli di santità, cit., but also: S. Shahar, Infants, Infant care, and Attitudes toward Infancy in the Medieval lives of Saints, in «The Journal of Psycohistory», X (1983), n. 1, pp. 12-23; e M. Goodich, From Birth to Old Age, New York-London, Lanham, 1989.

${ }^{87}$ On the possibility of a systematic use of hagiographic literature in this sense, in order to verify the «old hypothesis by Philippe Ariès on the absence of childhood in traditional societies», S. Vecchio expressed her opinion in the large review dedicated to the volume Bambini santi. Rappresentazioni dell'infanzia e modelli agiografici, in «Cristianesimo nella storia», XV (1994), n. 1, pp. 197-200.

${ }^{88}$ With regard to parish oratories we have some sector research, whose methodological approach, aimed at identifying and analyzing the educational strategies and the role of these institutions, seems to be particularly effective. See G. Barzaghi, Tre secoli di storia e pastorale degli Oratori milanesi, Leumann (Torino), LDC, 1985; G. Chiosso, L'oratorio di Don Bosco e il rinnovamento educativo nel Piemonte carloalbertino, in P. Braido (ed.), Don Bosco nella Chiesa a servizio dell'umanità. Studi e testimonianze, Roma, LAS, 1987, pp. 83-116; L. Caimi L'oratorio salesiano: la specificità di una proposta pedagogica, in Don Bosco. Ispirazione, proposte, strategie educative, Leumann (Torino), LDC, 1989, pp. 63-100; Id., Popolo e educazione cristiana: gli oratori (1945-'58), in L. Pazzaglia (ed.), Chiesa e progetto educativo nell'Italia del secondo dopoguerra 1945-1958, Brescia, La Scuola, 1988, pp. 210-238. 
Another important line of investigation is related to the experiences and initiatives of the male, and especially female, religious institutes, which in the nineteenth and twentieth century were devoted primarily to the care and support of childhood (kindergartens, orphanages etc.), to the education of the youth of different classes (schools, board schools, conservatories and girls' boarding schools etc.), and to religious animation and catechesis. On this side we already possess valuable synthesis of certain significant research at local level, at least for what concerns the nineteenth century ${ }^{89}$.

It is true, however, that much remains to be done, especially in relation to the charitable and educational work carried out by religious congregations in the twentieth century in the different areas of the country. A systematic analysis of the documents preserved in the provincial and local archives of the various institutes (regulations, didactic and educational programs, lists of texts and reading books, reports on training activities carried out by individual local authorities, statistics on pupils and news about their condition and social background etc.), allows us to fully assess the characteristics and dimensions of the charitable and educational work carried out by religious men and institutions, as well as the various initiatives for children they promoted.

Finally, we have to underline the importance, for the purposes of our discussion, of the studies and research in the field of the so-called Works of Piety, that included, after the national unification, the many and varied charitable institutions established in the previous decades thanks to ecclesiastical institutions and private benefactors ${ }^{90}$.

These include, for example: nursery school, the hospital institutions for orphaned and abandoned children (children's homes and orphanages) and for the youth in difficult conditions (retreats and female boarding schools for girls "in danger", reform schools for "naughty" boys), those for assistance and special education (schools and shelters for deaf and blind children and youth) ${ }^{91}$.

This is an undoubtedly important reality for understanding the methods and characteristics of the charitable and educational (or rehabilitation) interventions for the poor and disadvantaged children and youth in the united Italy. A reality, that of the Works

${ }^{89}$ See, in this regard: G. Rocca, Le nuove fondazioni religiose femminili in Italia dal 1800 al 1860, in Problemi di storia della Chiesa dalla Restaurazione all'unità d'Italia, Napoli, Dehoniane, 1985, pp. 107-192; Id., Istituti religiosi in Italia tra Otto e Novecento, in Clero e società nell'Italia contemporanea, Roma-Bari Laterza, 1992, pp. 207-256; Id., Aspetti istituzionali e linee operative nell'attività dei nuovi istituti religiosi, in L. Pazzaglia (ed.), Chiesa e prospettive educative in Italia tra Restaurazione e Unificazione, Brescia, La Scuola, 1994, pp. 173-200; P. Borzomati, Le nuove congregazioni religiose nel Mezzogiorno e Annibale Di Francia, Roma, Studium, 1992; P. Braido (ed.), Esperienze di pedagogia cristiana nella storia. Vol. II: Sec. XVII-XIX, Roma, LAS, 1981; R. Sani (ed.), Chiesa, educazione e società nella Lombardia del primo Ottocento. Gli Istituti religiosi tra impegno educativo e nuove forme di apostolato (1815-1860), cit.; M.T. Falzone, Le congregazioni religiose femminili nella Sicilia dell'Ottocento, Caltanissetta, Sciascia, 2002 ; M. Taccolini (ed.), A servizio dello sviluppo. L'azione economico-sociale delle congregazioni religiose in Italia tra Otto e Novecento, Milano, Vita e Pensiero, 2004; R. Sani, «Ad Maiorem Dei Gloriam». Istituti religiosi, educazione e scuola nell'Italia moderna e contemporanea, cit.

${ }^{90}$ See S. Lepre, Le difficoltà dell'assistenza. Le opere pie in Italia fra '800 e '900, Roma, Bulzoni, 1988 (of a legal- administrative character).

${ }^{91}$ See, for example: R. Sani (ed.), L'educazione dei sordomuti nell'Italia dell'800. Istituzioni, metodi, proposte formative, Torino, SEI, 2008; S. Polenghi, Educating the cripples. The Pious Institute for rickets sufferers of Milan and its transformations (1874-1937), Macerata, EUM, 2009; M.C. Morandini, La conquista della parola. L'educazione dei sordomuti a Torino tra Otto e Novecento, Torino, SEI, 2010. 
of Piety, which has been studied so far almost exclusively in legal and administrative terms $^{92}$, but that deserves a much greater attention by the historians of childhood and children's education.

But a wider survey, with the aim to bring out not only the substantial commitment in the charitable and educational fields but also the role of the Church in the creation, in the Italian society of the nineteenth and twentieth century, of a new "idea" of childhood, of a different "feeling" of the adults towards the child's world, must necessarily extend its attention to aspects, modalities and levels of religious and devotional practice for too long ignored - or prejudicially rejected - by a historiography on the "marginal people" (identified from time to time with the children, women, the poor, the insane etc..), indeed very little attentive to the socio-cultural and religious context within which the concrete experience of the studied subjects occurred.

There are many evidences proving the development, starting from the first half of the nineteenth century, of a new «feeling of childhood» within the Italian Catholicism:

- The growing attention to the problems of childhood education, resulting in the overcoming of the purely charitable logics of the previous phase ${ }^{93}$;

- The development, at the level of the catechesis and of the Christian education of youth, of an increasingly wide attention to the psychological dynamics of the child and the need to promote a genuine internalisation of the faith, which is matched to the gradual abandonment of the orientations and models of the traditional catechesis ${ }^{94}$;

- The gradual spread of a spirituality and a devotional practice more in line with the needs of the working classes and more careful to children's and teens' feelings.

It is sufficient to mention, for example, the overcoming of the rigorous austere spirituality of the eighteenth century and the introduction, since the early nineteenth century, of a Christian charity inspired by the spiritual writings by François de Sales, Filippo Neri, Alfonso Maria de' Liguori, and which includes, in the educational field (education of children and young people) values such gentleness, kindness, love, typical of the spiritual perspective of those authors ${ }^{95}$; the considerable fortune and diffusion recorded

92 See, in particular: V. Fargion, L'assistenza pubblica in Italia dall'Unità al fascismo, in «Rivista trimestrale di scienza dell'amministrazione», XXIV (1983), n. 2, pp. 46-58; S. Lepre, Per una storia dell'attività dell'amministrazione statale nel settore dell'assistenza, in M. Bigaran (a cura di), Istituzioni e borghesie locali nell'Italia liberale, Milano, Franco Angeli, 1986, pp. 127-145; F. Della Peruta, Le Opere Pie dall'Unità alla legge Crispi, in Problemi istituzionali e riforme nell'età crispina. Atti del LV Congresso di storia del Risorgimento italiano (Sorrento, 6-9 dicembre 1990), Roma, Istituto per la Storia del Risorgimento Italiano, 1992, pp. 193-249.

${ }^{93}$ For example, significant indications and confirmations on this side, the result of an interdisciplinary approach and a wide use of unpublished sources, came from a series of study conferences dedicated to a deep analysis of the educational commitment of the Italian Church in the last two centuries. See L. Pazzaglia (ed.), Chiesa e prospettive educative in Italia tra Restaurazione ed Unificazione, cit.; Id. (ed.), Chiesa e progetto educativo nell'Italia del secondo dopoguerra 1945-1958, cit.; Id. (ed.), Cattolici, educazione e trasformazioni socio-culturali in Italia tra Otto e Novecento, Brescia, La Scuola, 1999.

${ }^{94}$ See A. Etchegaray, Storia della catechesi, Roma, Paoline, 1965; e, soprattutto, P. Braido, Lineamenti di storia della catechesi e dei catechismi. Dal «tempo delle riforme» all'età degli imperialismi (1450-1870), Leumann (Torino), LDC, 1991.

95 See M. Marcocchi, Indirizzi di spiritualità ed esigenze educative nella società post-rivoluzionaria dell'Italia settentrionale, in L. Pazzaglia (ed.), Chiesa e prospettive educative in Italia tra Restaurazione e Unificazione, cit., pp. 83-122; M. Petrocchi, Schema per una storia della spiritualità italiana nell'Ottocento e 
by the new devotions centered on the family and on children, including those on the Holy Family, the Guardian Angel, the Child Jesus, St. Joseph (considered a model of charity and paternal sweetness) ${ }^{96}$; and finally, a religious iconography full of childhood and family pictures $^{97}$. They are, of course, aspects and themes that need further verification and investigation.

There is no doubt, however, that they testify the development of a new pastoral and educational sensitivity within the Church, destined to influence the same view of childhood and its problems.

In an important work on the religious mentality published a few years ago, Marina Caffiero suggested a kind of «feminisation of Catholicism between the eighteenth and nineteenth centuries» ${ }^{98}$. This hypothesis seems to be interesting, as well as the fact that this process of «feminisation of Catholicism» has occurred in a historical period which recorded the gradual emergence, at all levels (institutional, legal, economic, and also private), of a bourgeois authoritarianism and paternalism. We believe that the historical research on childhood and its education must face this profound change in the ecclesiastical and pastoral traditions and the more general transformations that marked the culture and the religious experience of our country in the nineteenth and twentieth century.

nel Novecento, ora in Id., Storia della spiritualità italiana, introduzione di P. Borzomati, Torino, SEI, 1996, pp. 244-274; R. Sani, Indirizzi spirituali e proposte educative dei nuovi Istituti religiosi dell'Ottocento in area lombarda, in Id. (ed.), Chiesa, educazione e società nella Lombardia del primo Ottocento. Gli Istituti religiosi tra impegno educativo e nuove forme di apostolato (1815-1860), cit., pp. 77-138.

${ }_{96}^{6}$ See, in this regard: M. Bendiscioli, La pietà specialmente del laicato sulla scorta dei manuali di devozione diffusi nell'Italia settentrionale, in Chiesa e religiosità in Italia dopo l'Unità (1861-1878), Milano Vita e Pensiero, 1973, 3 voll., II, pp. 154-176; P. Stella, Don Bosco nella storia della religiosità cattolica, Zurigo, PAS, 1968-1969, 2 voll.; Id., Prassi religiosa, spiritualità e mistica nell'Ottocento, in G. De Rosa, T. Gregory, A. Vauchez (edd.), Storia dell'Italia religiosa. 3. L'età contemporanea, Roma-Bari, Laterza, 1995, pp. 115-142; and, in particolar, the already mentioned A. DORDONI, I libri di devozione dell'Ottocento (con particolare riferimento alla produzione milanese): proposte per una lettura critica, cit., pp. 59-67.

${ }^{97}$ See A. Vecchi, Il culto delle immagini nelle stampe popolari, Firenze, Olschki, 1968; M. Falzone del Barbarò, Santi di pizzo. Immagini su carta intagliata dal XVII al XX secolo, Torino, D. Piazza, 1983; Con mano devota. Mostra delle immaginette spirituali manufatte, Padova, Edizioni Messaggero, 1985; M.T. Beife Casella, L'immaginetta di devozione strumento di divulgazione della dottrina cristiana (secoli XVIII-XIX), in Chiesa e società a Bergamo nell'Ottocento, cit., pp. 235-254.

${ }^{98}$ M. Caffiero, Un santo per le donne. Benedetto Giuseppe Labre e la femminilizzazione del cattolicesimo tra Settecento e Ottocento, «Memoria», 30 (1990), 3, pp. 89-106. Della stessa autrice si vedano inoltre: Ead., Femminile/popolare. La femminilizzazione religiosa nel Settecento tra nuove congregazioni e nuove devozioni, «Dimensioni e Problemi della Ricerca storica», 2 (1994), pp. 235-245; Ead., La politica della santità. Nascita di un culto nell'età dei Lumi, Roma-Bari, Laterza, 1996, specie p. 183 and following. For a picture of the consequences of this phenomenon on the pastoral life and on the religious practice of the nineteenth and twentieth centuries, with particular reference to the French reality, see Histoire religieuse de la France XIXe-XXe siècle, sous la direction de J.-M. Mayeur, Paris, Beauchesne, 1975. 
Cadernos de História da Educação, v.15, n.2, p. 347-401, maio-ago. 2016

ISSN: 1982-7806 (On Line)

DOI: $10.14393 /$ che-v15n2-2016-18

ARTIGOS

BILINGUAL EDITION: ENGLISH/ITALIAN

\title{
Per una storia dell'infanzia e della sua educazione nell'Italia contemporanea. Interpretazioni e prospettive di ricerca (Bilingue Edizione: Inglese / Italiano) ${ }^{99}$
}

\author{
For a history of childhood and of his education in contemporary Italy. Interpretations and \\ perspectives of research
}

Para uma história da infância e sua educação na Itália contemporânea.

Interpretações e perspectivas de pesquisa

\author{
ROBERTO SANI ${ }^{100}$
}

\section{Sommario}

La storia dell'infanzia e dell'educazione infantile ha conosciuto, in Italia, un effettivo sviluppo solamente nel corso degli ultimi quarant'anni. All'origine di siffatto ritardo si collocano diversi fattori. In primo luogo, il prevalere, fino agli anni Settanta, nell'ambito della storiografia italiana, della matrice etico-politica di derivazione hegeliano-idealistica, alla quale non hanno saputo sottrarsi neppure gli storici di formazione marxista. In secondo luogo, il grave ritardo con cui la ricerca storico-pedagogica - troppo a lungo confinata entro gli angusti limiti della storia delle dottrine pedagogiche e delle teorie filosofiche dell'educazione - ha maturato la propria identità e autonomia epistemologica e culturale e si è dotata delle metodologie e dei quadri concettuali propri dell'indagine storiografica. Il presente contributo si fonda sulla consapevolezza che la storia dell'infanzia - per il carattere «sfuggente» dell'oggetto da

99 I membri della Commissione Editoriale dei Quaderni di Storia dell'Educazione ringraziano la gentilezza della Professoressa Dr. Maria Helena Camara Bastos, della Pontificia Università Cattolica del Rio Grande del Sud (Porto Alegre, Rio Grande do Sul, Brasil) che ci ha fatto da intermediaria per l'invio di questa importante collaborazione del Professore Dr. Roberto Sani, dell'Università di Macerata (Italia).

${ }^{100}$ Professore ordinario di Storia dell'educazione. Università degli Studi di Macerata (Italy). E-mail: roberto.sani@unimc.it 
studiare e per il suo collocarsi in una zona di confine tra differenti settori e ambiti di ricerca implica un approccio articolato e complesso, capace di consentire diversi livelli di analisi e di lettura; necessita quindi dell'apporto di molteplici competenze storiografiche in prospettiva interdisciplinare (la storia sociale, quella delle istituzioni e delle pratiche educative, ma anche la storia della mentalità, dei processi culturali ecc.). Esso si compone di due parti distinte e intende focalizzare l'attenzione sulle indagini compiute, sulla situazione attuale e sui futuri sviluppi della ricerca nel settore. Nella prima parte, dopo aver fornito un'ampia rassegna delle ricerche e degli studi dedicati alla storia dell'infanzia e dell'educazione infantile pubblicati in Italia negli ultimi decenni, 1'Autore approfondisce talune questioni concernenti l'impostazione metodologica e storiografica di tali studi. In particolare, egli si sofferma su talune tematiche e questioni della storia dell'infanzia e della sua educazione ancora poco o per nulla indagate dagli studiosi, nonché sulla tendenza comune a diversi contributi apparsi negli ultimi decenni a definire e ad interpretare le vicende storiche dell'infanzia sulla base di un approccio per «modelli» desunto un po' acriticamente dalle scienze sociali, il quale, alla prova dei fatti, non sembra tenere adeguatamente presente la complessità dei processi storico-culturali ed educativi che hanno interessato la penisola. Nella seconda parte del lavoro, allo scopo di favorire l'ampliamento e l'affinamento dell'indagine storica su questo versante, l'Autore si propone di illustrare l'importanza che rivestono taluni itinerari di ricerca e talune fonti ancora poco o per nulla utilizzate dagli studiosi ai fini dell'approfondimento della storia dell'infanzia e della sua educazione nell'Italia contemporanea (secoli XIX-XX). Relativamente a questo aspetto, un'attenzione particolare è riservata al ruolo - ancora in larga misura da approfondire esercitato dalla Chiesa cattolica nell'assistenza e nell'educazione religiosa e civile dell'infanzia, come del resto nella costruzione di un determinato immaginario infantile nel mondo adulto.

\begin{abstract}
The history of childhood and childhood education has experienced, in Italy, a real development only in the last forty years. The reason of such a delay is due to several factors. First of all, the prevalence in the Italian historiography, until the seventies, of the ethical-political matrix derived from Hegel's idealism, which wasn't avoided not even by the Marxist historians. Secondly, the serious delay with which the historical-pedagogical research - for a too long period of time confined within the narrow limits of the history of pedagogical doctrines and of the philosophical theories of education- has developed its own cultural and epistemological identity and autonomy and the methodologies and conceptual frameworks typical of the historiographical research. This contribution is based on the awareness that the history of childhood - for the «elusive» character of the object to be studied and for its being placed in a border area between different sectors and fields of research - involves a complex and structured approach, able to allow different levels of analysis and reading; thus requiring the contribution of various historiographical skills in an interdisciplinary perspective (social history, that of institutions and educational practices, but also the history of mentalities, cultural processes, etc.). It consists of two separate parts, and is meant to focus on the previous investigations, on the current situation and on the future developments in this field of research. In the first part, after having provided an extensive review of the research and studies on the history of childhood and on childhood education published in Italy in the last decades, the Author analyzes certain issues relating to the methodological and historiographical organization of these studies . In particular, he focuses on some themes of the history of childhood and its education little or not at all investigated by scholars, as well as on the trend typical of several contributions appeared in the last decades to define and interpret the historical events of childhood on the basis of an approach using «models», derived, a little bit uncritically, from the social sciences, which does not seem to adequately take into
\end{abstract}


consideration the complexity of the educational and cultural-historical processes that have affected Italy. In the second part of the work, in order to facilitate the expansion and the refinement of the historical investigation on this issue, the Author aims to illustrate the importance of certain research and of some sources still little or not used by scholars to analyze the history of his childhood and education in contemporary Italy (XIX-XX centuries). For what concerns this aspect, a special attention is given to the role - still largely to be explored - of the Catholic Church in the support and in the religious and civil education of childhood, as well as in the construction of a certain children imagination in the adult world.

\section{Resumo}

A história da educação infantil e da infância conheceu, na Itália, um verdadeiro desenvolvimento somente nos últimos quarenta anos. A origem de tal atraso são colocados em vários factores . Em primeiro lugar, a prevalência , até que os setenta anos, como parte da historiografia italiana, a matriz derivada do ético-político - idealista de Hegel, que não tenham ainda sido capaz de evitar a formação de historiadores marxistas. Em segundo lugar, o grave atraso no histórico- pedagógico - levando tempo demais sendo confinados dentro dos limites estreitos da história das doutrinas teorias pedagógicas e filosóficas da educação - tem desenvolvido a sua própria identidade, autonomia, características culturais, epistemológicos metodologias e estruturas conceituais próprias do levantamento historiográfico. Esta contribuição é baseada na consciência de que a história da infância - para o personagem objeto «indescritível» a ser estudado e colocou-a em uma área de fronteira entre diferentes setores e campos de pesquisa - envolve uma abordagem complexa e multi- facetada, capaz de permitir diferentes níveis de análise e leitura; exige, portanto, a entrada de várias habilidades historiográficas em perspectiva interdisciplinar (história social, a de instituições e práticas de ensino, mas também a história das mentalidades, processos culturais, etc.). É composto por duas partes distintas, e pretende concentrar-se nas investigações realizadas, a situação atual e desenvolvimentos futuros no campo da pesquisa. Na primeira parte, após a apresentação de uma extensa revisão das pesquisas e estudos dedicado à história da educação infantil e da infância publicada na Itália nas últimas décadas, o autor investiga certas questões relativas à metodologia e historiografia desses estudos. Em particular, ele se concentra em determinados temas e questões da história da infância e da sua educação ainda pouco ou não investigado por estudiosos, bem como a tendência comum em diversas contribuições têm surgido nas últimas décadas para definir e interpretar os acontecimentos históricos de' infância com base em uma abordagem de «modelos» derivando um pouco de forma acrítica das ciências sociais, o que, na evidência dos fatos, não parecem ter devidamente em conta a complexidade dos processos de ensino e histórico-culturais que afetaram a península. Na segunda parte do trabalho, a fim de facilitar a expansão e o aperfeiçoamento da investigação histórica sobre este assunto, o autor tem como objetivo ilustrar a importância de certas rotas de pesquisa e algumas fontes ainda pouco ou nunca usadas, por estudiosos para aprofundar a história de sua infância e educação na Itália contemporânea (séculos XIX-XX). No que diz respeito a este aspecto, é dada especial atenção ao papel - ainda em grande parte a ser explorado - exercida pela Igreja Católica e na assistência da infância religiosa e civil, como a construção de um certo imaginário infantil em mundo adulto.

Recebido em: fevereiro de 2016 Aprovado para publicação em: abril de 2016 


\section{La recente storiografia sull'infanzia e sull'educazione infantile in Italia}

E' stato giustamente osservato che «la storia dell'infanzia e la sua individuazione come oggetto storiografico costituiscono una acquisizione recente della nostra cultura» ${ }^{101}$. Per lungo tempo infatti, a fronte del vivace sviluppo che tale settore d'indagine ha conosciuto in Francia e nei paesi anglosassoni, in Italia la ricerca storica - compresa quella d'indirizzo pedagogico ed educativo - ha dedicato scarsa attenzione alle condizioni sociali dell'infanzia e alle stesse immagini del bambino elaborate dal mondo adulto nelle diverse epoche $^{102}$.

All'origine di siffatta carenza si collocano diversi fattori. Innanzi tutto, il prevalere fino agli anni Settanta, nell'ambito della storiografia italiana, della matrice etico-politica di derivazione hegeliano-idealistica, alla quale, nonostante le decise polemiche e le contrapposizioni di carattere ideologico nei riguardi degli indirizzi storiografici tradizionali, non hanno saputo sottrarsi neppure gli storici di formazione marxista, nel cui approccio, come è stato efficacemente rilevato, non è difficile riscontrare «la permanenza di una struttura mentale "idealistica" nonostante le professioni di marxismo» ${ }^{103}$. In secondo luogo, il grave ritardo con cui la ricerca storico-educativa, troppo a lungo confinata entro gli angusti limiti della storia delle dottrine pedagogiche e delle teorie filosofiche sull'educazione, ha maturato la propria identità/autonomia epistemologica e culturale e si è dotata delle metodologie e degli strumenti propri dell'indagine storiografica ${ }^{104}$.

Negli ultimi decenni, comunque, gli studi di storia dell'infanzia hanno fatto registrare anche nel nostro paese un sensibile incremento. Rispetto infatti ai primi, pionieristici lavori di Dina Bertoni Jovine e di Leonardo Trisciuzzi ${ }^{105}$, il quadro si è arricchito di ricerche originali e di ampio respiro, caratterizzate in taluni casi da un

${ }^{101}$ E. Catarsi, L'infanzia nell'Italia unita. Riflessioni metodologiche e prospettive di ricerca, in A.M. Bernardinis, E. Bosna, F. Cambi, E. Catarsi, L. Trisciuzzi, Storiografia dell'Infanzia. Problemi e metodi, Ferrara, Biblioteca del Bollettino CIRSE, 1991, pp. 49-71.

102 Sul piano generale, si vedano N. Tranfaglia (ed.), L'Italia unita nella storiografia del secondo dopoguerra, Milano, Feltrinelli, 1980; e P. Rossi (ed.), La storiografia contemporanea. Indirizzi e problemi, Milano, Il Saggiatore, 1987; C. Cassina (ed.), La storiografia sull'Italia contemporanea, Pisa, Giardini, 1990. Con specifico riferimento alla storiografia pedagogica ed educativa cfr. E. Becchi, A. Semeraro (edd.), Archivi d'infanzia: per una storiografia della prima età, Scandicci, La Nuova Italia, 2001; e E. Becchi, Il bambino di ieri: breve storia di una storiografia, in «Studi sulla Formazione», XIII (2010), n. 1, pp. 9-24.

${ }^{103}$ D. Coli, Idealismo e marxismo nella storiografia italiana degli anni '50 e '60, in P. Rossi (a cura di), La storiografia contemporanea. Indirizzi e problemi, cit., p. 51 (ma si vedano le acute osservazioni avanzate in altre parti del saggio, pp. 38-58). Sulla storiografia marxista in Italia cfr. anche L. Masella, Passato e presente nel dibattito storiografico: storici marxisti e mutamento della società italiana (1955-1970), Bari, De Donato, 1979. Sulle difficoltà incontrate nel nostro paese dalla storia sociale e dai nuovi indirizzi di ricerca affermatisi in Francia e in Gran Bretagna, si vedano le riflessioni formulate in A.M. Banti, La storia sociale: un paradigma introvabile?, in C. Cassina (ed.), La storiografia sull'Italia contemporanea, cit., pp. 183-208.

${ }^{104}$ Cfr. A. Santoni Rugiu, Dalla storia dell'ideologia pedagogica alla storia sociale dell'educazione, in A. Santoni Rugiu, G. Trebisacce (edd.), I problemi epistemologici e metodologici della ricerca storicoeducativa, Cosenza, Pellegrini, 1983, pp. 61-70; R. Fornaca, La ricerca storico-pedagogica, Scandicci, La Nuova Italia, 1988; F. Cambi, La ricerca storico-educativa in Italia 1945-1990, Milano, Mursia, 1992, pp. 11-54; e R. Fornaca, La ricerca storico-educativa. Riflessioni e prospettive, in «Nuovo Bollettino CIRSE», I (2006), n. 1-2, pp. 21-26.

${ }^{105}$ D. Bertoni Jovine, L'alienazione dell'infanzia, Roma, Editori Riuniti, 1963; L. Trisciuzzi, La scoperta dell'infanzia, Firenze, Le Monnier, 1976. 
approccio di tipo interdisciplinare e dal ricorso a fonti e a materiali documentari poco o nulla sfruttati in precedenza. Penso, innanzi tutto, alle stimolanti indagini condotte da Egle Becchi e dal gruppo di ricerca pavese che a lei fa capo, il quale è venuto via via ampliando i propri interessi di studio, stabilendo altresì feconde collaborazioni e sinergie con studiosi e ricercatori d'oltralpe ${ }^{106}$.

Tra $\mathrm{i}$ frutti più interessanti del lavoro condotto da tale gruppo si colloca in primo luogo la Storia dell'infanzia curata dalla stessa Egle Becchi e da Dominique Julia: tentativo in larga misura riuscito di ricomporre in una vasta e organica sintesi le conoscenze acquisite dalla storiografia europea intorno alla condizione dell'infanzia dall'antichità a oggi ${ }^{107}$.

Con specifico riferimento alla realtà italiana dell'Otto e del Novecento meritano di essere segnalati, inoltre, taluni contributi di storia locale ${ }^{108}$ e, soprattutto, il pregevole lavoro di Franco Cambi e Simonetta Ulivieri sulla Storia dell'infanzia nell'Italia liberale, nel quale risultano efficacemente indagati tanto gli aspetti relativi alla storia sociale e dell'educazione (condizioni dell'infanzia, pratiche formative ecc.), quanto quelli che attengono alla storia della mentalità e dell'immaginario collettivo (concezioni, ideologie, "immagini" dell'infanzia ecc.) ${ }^{109}$.

Un'interessante occasione di confronto tra storici della pedagogia e studiosi di storia sociale e politica in ordine alla condizione dell'infanzia nell'Italia contemporanea è venuta, al principio degli anni Novanta, dal seminario di studi interdisciplinari sul tema $\mathrm{Il}$ bambino nella storia, promosso a Perugia nel 1991 dal gruppo di ricerca coordinato da Maria Cristina Giuntella ${ }^{110}$. A questo primo appuntamento ha fatto seguito, qualche anno più tardi, quello altrettanto significativo promosso dall'École Française de Rome sul tema Pédagogie et liturgie nationale dans l'Italie post-unitaire. Histoire et historiographie de l'enfance $^{111}$.

Tra i contributi sulla storia dell'infanzia e della sua educazione che hanno visto la luce in Italia negli ultimi decenni, infine, debbono essere ricordate le pregevoli raccolte di

${ }^{106} \mathrm{Si}$ vedano in particolare E. Becchi (ed.), Il bambino sociale. Privatizzazione e deprivatizzazione dell'infanzia, Milano, Feltrinelli, 1979; E. Becchi, M. Ferrari, M. Grandini, S. Micotti, Per una storia dell'infanzia come figura educativa, in E. Becchi (a cura di), Storia dell'educazione, Scandicci, La Nuova Italia, 1987; R. Balzarini et alii, Segni d'infanzia. Crescere come re nel Seicento, Milano, Franco Angeli, 1991; E. Becchi, I bambini nella storia, Roma-Bari, Laterza, 1994; Q. Antonelli, E. Becchi (edd.), Scritture bambine. Testi infantili tra passato e presente, Roma-Bari, Laterza, 1995; E. Becchi, A. Semeraro (edd.), Archivi d'infanzia. Per una storiografia della prima età, Scandicci, La Nuova Italia, 2001; M. Ferrari (ed.), I bambini di una volta. Problemi di metodo. Studi per Egle Becchi, Milano, Franco Angeli, 2006.

${ }^{107}$ E. Becchi, D. Julia (edd.), Storia dell'Infanzia, Roma-Bari, Laterza, 1996, 2 voll.

${ }^{108}$ Cfr. F. Della Peruta, Infanzia e famiglia nella prima metà dell'Ottocento, «Studi Storici», 1979, n. 3, pp. 473-491; A.M. Bernardinis (ed.), Il bambino e la sua cultura nella Padova dell'Ottocento, Comune di Padova, Padova 1981; L. Dalle Nogare, L. Finocchi (edd.), Nascere, sopravvivere e crescere nella Lombardia dell'Ottocento (1815-1915), Milano, Silvana Editoriale, 1981; Comune di Modena, Per amore e per forza. L'infanzia tra Ottocento e Novecento, Modena, Edizioni Panini, 1987.

${ }^{109}$ Cfr. F. Cambi, S. Ulivieri, Storia dell'infanzia nell'Italia liberale, Scandicci, La Nuova Italia, 1988.

${ }^{110}$ Se ne vedano gli atti in M.C. Giuntella, I. Nardi (edd.), Il bambino nella storia. Atti del Seminario di Studi Interdisciplinare (Perugia, 14-15 giugno 1991), Napoli, ESI, 1993.

${ }^{111}$ Pédagogie et liturgie nationale dans l'Italie post-unitaire. Histoire et historiographie de l'enfance, in «Mélanges de l'École française de Rome. Italie et Méditerranée», 109 (1997), n. 1, pp. 3-483. 
studi su Le bambine nella storia dell'educazione, a cura di Simonetta Ulivieri ${ }^{112}$, Itinerari nella storia dell'infanzia, a cura della stessa Ulivieri e di Carmela Covato ${ }^{113}$; infine, Infanzia, educazione e società in Italia tra Otto e Novecento, a cura di Luciano Caimi ${ }^{114}$.

Sullo sviluppo di quello che si configura ormai, anche in Italia, come uno specifico e autonomo settore di ricerca hanno influito, mi sembra, due apporti convergenti:

1) in primo luogo, il confronto con gli studi e le ricerche sulla storia dell'infanzia avviati in Francia, in Germania e nei paesi anglosassoni. Intendo riferirmi, innanzi tutto, al fondamentale lavoro di Philippe Ariès su L'enfant et la vie familiale sous l'ancien régime (1960) e alle successive indagini di questo studioso e di altri autori che si sono collocati sulla sua linea interpretativa ${ }^{15}$; come pure alle ricerche coordinate da Lloyd de Mause e raccolte nel volume The history of childhood (1974), nel quale è delineata un'interpretazione del significato e delle condizioni di vita dell'infanzia radicalmente diversa rispetto a quella offerta da Ariès ${ }^{116}$; allo stimolante contributo di Dieter Richter su Das fremde Kind. Zur Entstehung der Kindheitsbilder des burgerlichen Zeitalsters (1987), che ha approfondito l'immagine dell'infanzia in epoca moderna attraverso l'uso di fonti narrative di diverso genere e provenienza ${ }^{117}$; e, infine, ad alcune ricerche di ampio respiro che recentemente hanno visto la luce in ambito europeo ${ }^{118}$;

${ }^{112}$ S. Ulivieri (ed.), Le bambine nella storia dell'educazione, Roma-Bari, Laterza, 1999.

113 C. Covato, S. Ulivieri (edd.), Itinerari nella storia dell'infanzia. Bambine e bambini, modelli pedagogici e stili educativi, Milano, Unicopli, 2001.

114 L. Caimi (ed.), Infanzia, educazione e società in Italia tra Otto e Novecento. Interpretazioni, prospettive di ricerca, esperienze in Sardegna, Sassari, EDES, 1997.

${ }^{115}$ Il lavoro di Ph. Ariès (Paris, Plon, 1960), tradotto in italiano nel 1968 con il titolo Padri e figli nell'Europa medievale e moderna, è stato più volte ristampato nel nostro paese. Dello stesso Ariès si vedano anche: Le rôle nouveau de la mère et de l'enfant dans la famille moderne, in "Carnets de l'Enfance», giugno 1969, n. 10, pp. 36-43; la Préface à la nouvelle édition del volume L'enfant et la vie familiale... (Paris, Editions du Seuil, 1973, pp. I-XX); Enfant et société. Période moderne. Rapport introductif, in «Annales de Démographie Historique», XI (1973), pp. 211-224; Educazione, in Enciclopedia, Torino, Einaudi, 1978, V, pp. 251-259; Pour une histoire de la vie privée, in Ph. Ariès, G. Duby (edd.), Histoire de la vie privée. III. De la Renaissance aux Lumières, Paris, Editions du Seuil, 1986, pp. 7-19; J.-B. Pontalis, F. Gontheret, Conversazione con Ph. Ariès, in Il mondo dell'infanzia, trad. it., Roma, Savelli, 1981. Sul dibattito suscitato dall'opera di Ph. Ariès si veda ora l'attenta ricostruzione di E. Becchi, D. Julia, Storia dell'infanzia, storia senza parole?, in Eads. (edd.), Storia dell'Infanzia. 1. Dall'antichità al Seicento, cit., pp. XII-XXVII. Un'approfondita analisi dell'apporto di Ph. Ariès alla storiografia sull'infanzia è offerta da M.T. Maiocchi (a cura di), Edipo in società. Nascita del sentimento familiare e ideale dell'infanzia, Milano, Feltrinelli, 1983. Sulla linea interpretativa tracciata da Ph. Ariès si collocano, fra gli altri: J. Gelis, M. Laget, M.F. Morel, Entrer dans la vie. Naissances et enfances dans la France traditionelle, Paris, Gallimard, 1980; Enfant et société, «Annales de Démographie Historique», XI (1970), numero speciale.

${ }^{116}$ New York, Psychohistory Press, 1974-75 (una traduzione parziale del lavoro è apparsa in Italia con il titolo: Storia dell'infanzia, Milano, Emme, 1983). Sui limiti e le ambiguità dell'approccio alla storia dell'infanzia proposto da Lloyd De Mause e dal gruppo di studiosi che si richiamano all'indirizzo della psicostoria, si vedano le acute e condivisibili critiche formulate da J. Topolski, La storiografia contemporanea, Roma, Editori Riuniti, Marsilio, 1981, pp. 242-244; e, successivamente, da G. Starace, Le storie, la storia. Psicoanalisi e mutamento, Venezia, Marsilio, 1989, p. 97. Si veda anche L. Stone, The Massacre of the Innocents, in «New York Review of Book», 14 novembre 1974, n. 18, pp. 25-31.

${ }^{117}$ Frankfurt am Main, Fischer Verlag, 1987 (se ne veda ora la traduzione italiana a cura di P. Viti: Il bambino estraneo. La nascita dell'immagine dell'infanzia nel mondo borghese, Scandicci, La Nuova Italia, 1992). Sulla rappresentazione dell'infanzia attraverso le fonti letterarie si vedano anche: J. Calvet, L'enfants dans la littérature française. Des origines à 1870, Paris, Lanore, 1930; P. Coveney, The image of Childhood. The individual and society: a study of the theme in english literature, London, Penguin, 1967; K. Arnold, Kind und Gesellschaft in Mittelalter und Reinaissance. Beitrage und texte zur Geschichte der Kindheit, 
2) in secondo luogo l'adozione di indirizzi e di metodologie di ricerca che solo negli ultimi decenni hanno trovato adeguata ricezione nel nostro paese. Penso, ad esempio, alle prospettive di tipo metodologico e soprattutto ai nuovi filoni d'indagine (i «marginali», la «storia della mentalità» ecc.) proposti dalla storiografia delle Annales ${ }^{119}$ e dalla social history di matrice anglosassone (Lawrence Stone e il gruppo di studiosi raccolti attorno alla rivista «Past and Present») ${ }^{120}$; come pure alle suggestioni fornite agli storici dell'infanzia dalle indagini di carattere epistemologico di Michel Foucault ${ }^{121}$, dai raffinati lavori sulla storia dei processi di civilizzazione di Norbert Elias ${ }^{122}$, dai contributi degli studiosi statunitensi che si richiamano alla Psychohistory (da Erik H. Erikson a David Hunt, da John Demos al già ricordato Lloyd de Mause) ${ }^{123}$.

Tra le acquisizioni e i risultati più significativi raggiunti dalle ricerche e dagli studi avviati negli ultimi decenni nel nostro paese mi sembra debbano essere richiamati:

a) la consapevolezza che la storia dell'infanzia - per il carattere "sfuggente" dell'oggetto da studiare e per il suo collocarsi in una zona di confine tra differenti settori e ambiti di ricerca - implica un approccio articolato e complesso, capace di consentire diversi livelli di analisi e di lettura; necessita quindi dell'apporto di molteplici competenze storiografiche in prospettiva interdisciplinare (la storia sociale, quella delle istituzioni e delle pratiche educative, ma anche la storia della mentalità, dei processi culturali ecc.);

b) lo spazio e l'attenzione accordati (penso in particolare alle ricerche condotte da Egle Becchi e dal gruppo di ricercatori e di studiosi pavese) a fonti e a materiali documentari troppo a lungo trascurati o del tutto ignorati dalla tradizionale ricerca storicopedagogica sull'infanzia, almeno nel nostro paese: l'iconografia, la memorialistica, i giochi e i giocattoli, l'abbigliamento infantile, gli arredi, la stampa illustrata e la letteratura per l'infanzia;

Paderbon, Schoningh, 1980; e i saggi raccolti in D. Escarpit (ed.), The portrayal of the Child in Children's Literature, Munchen-New York, P. Lang, 1985.

${ }^{118}$ Si vedano in particolare: B. Delgado, Historia de la infancia, Ariel, Barcelona, 1998 (trad. it.: Bari, Dedalo, 2002); H. Cunningham, Children \& Childhood in Western Society since 1500 (Studies In Modern History), London, Routledge, 1996 (trad. it.: Bologna, Il Mulino, 1997); Id., The Invention of Childhood, London, BBC Books, 2006; P. Dávila, L.M. Maya (edd.), La infancia en la historia: espacios y representaciones, Donostia, EREIN, 2005, 2 voll.; H. Cazes (ed.), Histoires d'enfants. Représentations et discours de l'enfance sous l'Ancien Régime, Laval, Presses Universitaires de Laval, 2008.

${ }^{119} \mathrm{Cfr}$. T. Stoianovich, La scuola storica francese. Il paradigma delle «Annales», trad. it., Milano, ISEDI, 1978; e soprattutto G. Gemelli, Le «Annales» nel secondo dopoguerra: un paradigma?, in P. Rossi (ed.), La storiografia contemporanea. Indirizzi e problemi, cit., pp. 6-38. Per un quadro dei più recenti indirizzi e filoni di ricerca della nouvelle histoire francese si veda J. Le Goff (edd.), La nuova storia, trad. it., Milano, Mondadori, 1980.

${ }^{120}$ Cfr. J. Simon, The history of education in Past and Present, in «Oxford Review of Education», XXVI (1977), 1, pp. 23-41. Si veda anche G. Ricuperati, La storia dell'istruzione nella storiografia contemporanea, in Storia della scuola e storia d'Italia dall'Unità ad oggi, Bari, De Donato, 1982, pp. 83-86.

${ }^{121}$ Cfr. P. Veyne, Foucault révolutionne l'histoire, in Id., Comment on écrit l'histoire, Paris, Editions du Seuil, 1973. Si vedano anche le osservazioni formulate da F. Cambi, La storia dell'infanzia. Questioni di metodo, in Storiografia dell'Infanzia. Problemi e metodi, cit., pp. 34-35.

${ }_{122}$ Cfr. A. Roversi, Norbert Elias e la riscoperta di Kronos, in La storia comparata. Approcci e prospettive, Milano, Il Saggiatore, 1990, pp. 55-70; e l'Introduzione dello stesso Roversi all'edizione italiana di N. Elias, Il processo di civilizzazione, Bologna, Il Mulino, 1988, pp. 11-42.

${ }^{123}$ Cfr. L. La Penna, La «Psychohistory»: proposte e studi nella storiografia americana, in «Quaderni Storici», XVI (1981), n. 47, pp. 574-604; e Id., La psico-storia americana tra psicoanalisi e psicologia accademica, in P. Rossi (ed.), La storiografia contemporanea. Indirizzi e problemi, cit., pp. 264-284. 
c) l'impegno volto ad operare una saldatura, nelle ricostruzioni dedicate all'infanzia e alla sua educazione, tra la storia sociale e quella della mentalità: due prospettive d'indagine molto diverse, il cui incrocio consente di cogliere il complesso - e talora contraddittorio - rapporto tra l'immaginario elaborato dal mondo adulto sull'infanzia e i comportamenti e le pratiche che una determinata società sviluppa nei riguardi dei bambini.

A fronte di tali importanti acquisizioni, i lavori sopra richiamati e, più in generale, le diverse ricerche di storia dell'infanzia avviate negli ultimi anni lasciano intravedere una serie di problemi che in questa sede vale almeno la pena di sollevare.

Una prima questione di carattere generale: mentre su alcuni significativi nodi e problemi della storia dell'infanzia e della sua educazione disponiamo, per ciò che attiene alla realtà italiana, di numerose e documentate ricerche settoriali e di pregevoli indagini a carattere locale, condotte su un arco di tempo sufficientemente vasto e tale da consentire comparazioni e confronti per aree geografiche, su altri aspetti e problemi la ricerca di base è ancora agli inizi, i quadri di riferimento locali e $\mathrm{i}$ dati quantitativi risultano essere nel complesso scarsi, generici, approssimativi. Due esempi fra i tanti che si potrebbero fare:

1) la gran messe di studi relativi a fenomeni quali l'abbandono e l'esposizione infantile in epoca moderna e contemporanea ${ }^{124}$ e, per contro, la sostanziale carenza di ricostruzioni serie e documentate sulle molteplici e variegate istituzioni assistenziali (conservatori femminili, ospizi per fanciulli orfani e abbandonati, brefotrofi ecc.) ${ }^{125}$;

${ }^{124}$ Tra i lavori più significativi apparsi su tale versante negli ultimi decenni debbono essere segnalati: M. Gorni, L. Pellegrini, Un problema di storia sociale. L'infanzia abbandonata in Italia nel secolo XIX, Firenze, La Nuova Italia, 1974; S. Pagano, Gli esposti dell'Ospedale di S. Spirito nel primo Ottocento, in «Ricerche per la Storia Religiosa di Roma», 3 (1979), pp. 353-392; G. Da Molin, L'infanzia abbandonata in Italia nell'età moderna, Bari, Università degli Studi, 1981; i contributi sul tema raccolti in S.I.D.E.S., La demografia storica delle città italiane, Bologna, Clueb, 1982; e in G. Politi, M. Rosa, F. Della Peruta (edd.), Timore e carità. I poveri nell'Italia moderna, Cremona, Annali della Biblioteca statale e Libreria civica, 1982; V. Hunecke, I trovatelli di Milano. Bambini esposti e famiglie espositrici dal XVII al XIX secolo, Bologna, Il Mulino, 1988; G. Di Bello, Senza nome né famiglia. I bambini abbandonati nell'Ottocento, Firenze, Manzuoli, 1989; G. Da Molin, Nati e abbandonati. Aspetti demografici e sociali dell'infanzia abbandonata in Italia nell'età moderna, Bari, Cacucci, 1993; G. Da Molin (ed.), Trovatelli e balie in Italia secc. XVI-XIX. Atti del Convegno "Infanzia abbandonata e baliatico in Italia (secc. XVI-XIX)», Bari, 20-21 maggio 1993), Bari, Cacucci, 1994; A. Carbone, Esposti e orfani nella Puglia dell'Ottocento, Bari, Cacucci, 2000; C. Grandi, «Benedetto chi ti porta, maledetto chi ti manda». L'infanzia abbandonata nel Triveneto (secoli $X V$-XIX), Treviso, Edizioni Fondazione Benetton Studi Ricerche - Canova, 1997; S. Polenghi, S., Fanciulli soldati: la militarizzazione dell'infanzia abbandonata nell'Europa moderna, Roma, Carocci, 2003; A. Palombarini, Gettatelli e trovatelli: $i$ bambini abbandonati nelle Marche: $16^{\circ}-20^{\circ}$ secc., Ancona, Affinità elettive, 2005.

${ }^{125}$ Si veda il documentato quadro offerto da E. Bressan, E., Carità e assistenza, pubblico e privato: una riflessione storiografica, in M. Taccolini (ed.), Dalla beneficenza alla cultura del dono, Rudiano (Brescia), GAM, 2012, pp. 93-110. Tra i rari lavori di cui disponiamo in tale ambito, si vedano: Sistemi di carità, in «Quaderni Storici», XVIII (1983), n. 53 (fascicolo monografico); A. Buttafuoco, Le Mariuccine. Storia di un'istituzione laica, l'asilo Mariuccia, Milano, Franco Angeli, 1985; E. Baio, La condizione delle orfane alla "Stella" di Milano tra Ottocento e Novecento, in «Sanità scienza e storia», 2 (1985), n. 2, pp. 141-178; G. Botti, L. Guidi, L. Valenzi (a cura di), Povertà e beneficenza tra Rivoluzione e Restaurazione, Napoli, Morano, 1989; S. Fronzoni, Lontano dalla madre: forme e istituti dell'esposizione a Bologna nella prima metà dell'Ottocento, in: «Sanità Scienza e Storia», VI (1989), n. 2, pp. 55-76; V. Nuti, Discoli e derelitti. L'infanzia povera dopo l'Unità, Firenze, La Nuova Italia, 1992; A. Groppi, I conservatori della virtù. Donne recluse nella Roma dei papi, Roma-Bari, Laterza, 1994; e A. Semeraro (ed.), L'infanzia e le sue storie in terra d'Otranto, Lecce, Conte, 1999). 
2) sappiamo moltissimo sul dibattito pedagogico e sui modelli e sistemi di educazione infantile elaborati nel corso dell'Otto e del Novecento (dagli asili aportiani ai giardini d'infanzia froebeliani, ai metodi messi a punto dalle sorelle Agazzi e da Maria Montessori ecc.) ${ }^{126}$, mentre disponiamo di scarse notizie riguardo alle reali condizioni di funzionamento e alle concrete pratiche formative attuate negli asili infantili pubblici e privati trasformati, all'indomani dell'unificazione nazionale, in Opere Pie ${ }^{127}$.

Un ulteriore motivo di riflessione concerne il prevalere, in talune ricostruzioni, del momento descrittivo su quello interpretativo/valutativo. Soprattutto nelle opere di sintesi peraltro pregevoli, in quanto offrono un ampio spaccato della vita dell'infanzia nel corso delle varie epoche storiche - è dato di riscontrare una sovrabbondanza di elementi descrittivi, di cui talora non è sempre facile cogliere il significato più profondo, individuare il riferimento ad un determinato quadro concettuale, a un'ipotesi interpretativa generale.

Per contro, mi sembra ampiamente condivisibile il rilievo formulato da taluni studiosi riguardo al persistere, anche nei contributi di storia dell'infanzia apparsi nel nostro paese, di «forzature sovrainterpretative» ${ }^{128}$, già peraltro riscontrate in tanta parte della produzione storiografica straniera $^{129}$.

Non si può non rilevare, a questo proposito, come certe ipotesi generali sul destino dell'infanzia nella società contemporanea, come quelle incentrate sul concetto di «privatizzazione del bambino» ${ }^{130}$ o sul principio della «doppia alienazione» che caratterizzerebbe il mondo infantile ${ }^{131}$, tendano a porre sullo stesso piano - almeno per ciò

${ }^{126}$ A titolo puramente esemplificativo, ricordiamo fra gli altri: A. Gambaro, C. Calò, A. Agazzi, Aporti nel primo centenario della morte, Brescia, La Scuola, 1962; R. Mazzetti, Pietro Pasquali, le Agazzi e la riforma del froebelismo in Italia, Roma, Armando, 1962; D. Gasparini, Il pensiero pedagogico di A. Pick, Firenze, C.D.N.S.D., 1968-1970, 3 voll.; A. Gambaro, Ferrante Aporti e gli asili nel Risorgimento. Storia e critica, in F. Aporti, Scritti pedagogici e lettere, Brescia, La Scuola, 1976, pp. 3-321; E. Catarsi, G. Genovesi, L'infanzia a scuola. L'educazione infantile in Italia dalle sale di custodia alla materna statale, Bergamo, Juvenilia, 1985; E. Catarsi, L'educazione "prescolastica" nell'Italia giolittiana, in Id., L'educazione del popolo. Momenti e figure dell'istruzione popolare nell'Italia liberale, Bergamo, Juvenilia, 1985, pp. 183-211; S.S. Macchietti, La scuola infantile tra politica e pedagogia dall'età aportiana ad oggi, Brescia, La Scuola, 1985; C. Sideri, Ferrante Aporti. Sacerdote, italiano, educatore. Biografia del fondatore delle scuole infantili in Italia sulla base di nuova documentazione inedita, Milano, Franco Angeli, 1999; M. Piseri, Ferrante Aporti nella tradizione educativa lombarda e europea, Brescia, La Scuola, 2008.

${ }^{127}$ Sulla legislazione relativa alle Opere Pie nella stagione postunitaria, si vedano: S. Lepre, Le difficoltà dell'assistenza. Le Opere Pie in Italia fra '800 e '900, Roma, Bulzoni, 1988; F. Della Peruta, Le Opere Pie dall'Unità alla Legge Crispi, in «Il Risorgimento. Rivista di storia del Risorgimento e di storia contemporanea», XLIII (1991), n. 2-3, 1991, pp. 173-213; G. Farrell-Vinay, Povertà e politica nell'Ottocento. Le Opere Pie nello Stato liberale, Torino, Paravia, 1997; A. Fiori, Poveri, Opere pie e assistenza dall'Unità al fascismo, Roma, Studium, 2005;

${ }^{128}$ Così E. Catarsi, L'infanzia nell'Italia unita, cit., pp. 50-51. Ma si veda anche C. Pancera, Per una interpretazione della storia dell'infanzia, in «Studi di storia dell'educazione», 4 (1983), n. 3, pp. 46-58.

${ }^{129}$ Cfr. l'intervento un po' datato, ma ancora ricco di stimoli di E. Becchi, Molte infanzie, poche storie, in «Ricerche Pedagogiche», 18 (1983), n. 68-69, pp. 9-10.

${ }_{130} \mathrm{Si}$ veda in proposito E. Becchi (ed.), Il bambino sociale. Privatizzazione e deprivatizzazione dell'infanzia, Milano, Feltrinelli, 1979.

${ }^{131}$ Hanno scritto in proposito Franco Cambi e Simonetta Ulivieri: «L'alienazione del bambino borghese è connessa al conformismo, al controllo degli adulti, alla repressione degli istinti (del gioco libero, della libera socializzazione, del sesso) che esso subisce e, se pure si manifesta - rispetto a quella tipica delle classi popolari, che ha i caratteri duri dello sfruttamento - come un'alienazione "dorata", essa rivela comunque sempre un'espropriazione reale esercitata sul bambino, sul suo se-stesso più profondo. Le due alienazioni materiale e morale l'una, spirituale e psicologica l'altra - sono parallele: indicano un destino comune 
che riguarda gli esiti finali, i risultati del processo - itinerari di crescita e percorsi esperienziali talora radicalmente diversi, quali ad esempio quelli che nel corso dell'Ottocento e della prima metà del Novecento hanno caratterizzato l'infanzia delle classi contadina e proletaria urbana da un lato e quella dei ceti benestanti e del mondo borghese dall'altro.

Molto opportunamente Enzo Catarsi ha sottolineato, qualche anno fa, come, «ragionando in termini di storia sociale», non si possa «considerare alla stessa stregua lo sfruttamento bestiale dei bambini delle classi popolari e l'alienazione dorata dei figli degli abbienti» ${ }^{132}$. Aggiungerei che, di là della oggettiva difficoltà di giustificare sul piano storiografico equiparazioni e/o parallelismi tra condizioni sociali e culturali, modi di essere, esperienze di vita tanto differenti, il rischio sotteso a certe interpretazioni generali è quello di reintrodurre, nella spiegazione dei fatti storici, una sorta di schema ideologico, più o meno aggiornato e in sintonia con talune tendenze del dibattito culturale attuale.

C'è, infine, un ultimo aspetto sul quale mi sembra opportuno portare la discussione, anche perché esso attiene all'impostazione stessa di tanta parte della ricerca condotta in Italia. Mi riferisco alla tendenza comune a diversi contributi apparsi negli ultimi decenni a definire e ad interpretare le vicende storiche dell'infanzia sulla base di un approccio per "modelli" (essenzialmente tre: infanzia borghese, infanzia popolare urbana, infanzia contadina); i quali "modelli" rappresenterebbero il risultato delle più generali condizioni socio-economiche e della struttura classista della società.

Ora, nel caso dell'Italia post-unitaria, mi sembra si presentino non poche difficoltà a calare questo schema di lettura per "modelli", desunto dalle scienze sociali, nelle reali contingenze storiche e a legittimarne la funzione interpretativa senza operare forzature e semplificazioni della realtà. L'esempio più rilevante di tale difficoltà a far coincidere una "lettura per modelli" della realtà italiana con i reali processi storico-culturali si ritrova, a mio avviso, proprio nella determinazione/definizione del cosiddetto «modello borghese», assunto come espressione degli orientamenti e delle strategie delle classi dominanti.

\section{Il «modello borghese»: forzature e limiti di un approccio metodologico e euristico}

Nel passaggio dalla definizione teorica del «modello borghese» alla verifica storica della funzione ed incidenza che tale modello ha esercitato a livello di scelte culturali, processi formativi, pratiche educative e scolastiche, politiche sociali, ma anche di «sentimento dell'infanzia», ossia di produzione di un determinato «immaginario collettivo»

dell'infanzia - pur nella profonda diversità dei percorsi (fatto di lavoro-emarginazione-ignoranza/miseria il primo, di famiglia-conformismo-controllo/repressione il secondo) -, destino che sottolinea la sua totale subalternità al mondo adulto-sociale, la sua estraneità (come in-sé) alla cultura (o culture) dominante, la necessità di appropriazione-assimilazione che gli adulti esercitano su quella età "preziosa" e "favolosa", ma anche "perversa" e "deviante". La doppia alienazione agisce non solo a livello di condizioni di vita, di pratiche educative/formative, di comportamenti effettivi, ma anche attraverso l'immaginario, vincolando ai propri modelli la mentalità perfino nelle forme più astratte e simboliche» (F, Cambi, S. Ulivieri, Storia dell'infanzia nell'Italia liberale, cit., p. 272).

${ }^{132}$ E. Catarsi, L'infanzia nell'Italia unita, cit., p. 51. 
sul bambino (destinato, secondo talune interpretazioni, ad assurgere ad un ruolo egemonico), si pongono una serie di problemi.

In primo luogo: borghesia o borghesie? Nel sessantennio che dall'unificazione nazionale giunge fino all'avvento del fascismo si può parlare, per il nostro paese, di borghesia come soggetto unitario sotto il profilo culturale e politico? Per meglio dire: esiste un unico «modello borghese», identificabile tout court con quello politicamente egemone?

Le modalità stesse con cui si compie il processo unitario, la particolare connotazione assunta dai rapporti tra Stato e Chiesa (considerati, naturalmente, non in senso diplomatico-istituzionale, ma come fattore destinato a incidere sul costume civile e culturale e sulle coscienze individuali), le caratteristiche precipue assunte dalla cultura cattolica dell'epoca (il difficile rapporto con la modernità e con le sue conquiste ecc.) inducono, mi sembra, a maggiore cautela nell'assumere una "modellistica" dei rapporti culturali, sociali e politici capace di rappresentare senza forzature e semplificazioni la realtà italiana ${ }^{133}$.

Si potrebbe anche far rilevare che l'Italia postunitaria si presenta come una realtà estremamente variegata e composita, con differenze economiche e sociali (nord/sud, città/campagna, sviluppo/arretratezza ecc.), ma anche e soprattutto culturali, destinate ad incidere profondamente sulle stesse caratteristiche e aspirazioni delle élites borghesi e dei ceti possidenti locali ${ }^{134}$.

L'altra questione sulla quale mi sembra necessario richiamare l'attenzione è quella relativa al ruolo della Chiesa e del cattolicesimo italiano nella storia dell'infanzia e della sua educazione tra Otto e Novecento. Non credo di esagerare nell'affermare che, curiosamente, proprio la Chiesa è la grande assente o, per meglio dire, la grande dimenticata nelle ricostruzioni storiografiche sopra richiamate.

Un'assenza di questo tipo, indubbiamente, fa riflettere. A meno che, infatti, non si sia voluto - non si voglia - identificare tout court l'operato della Chiesa e del mondo cattolico nel suo complesso con quello delle classi dirigenti, considerando il loro apporto in termini di mera funzionalità e di subalternità rispetto alla costruzione del "modello" culturale e ideologico/pedagogico borghese (nella duplice accezione di messa a punto di indirizzi, strategie, pratiche di carattere educativo e di elaborazione di una determinata

${ }^{133}$ Per un approfondimento di tali questioni si vedano in particolare: G. Rossini (ed.), Aspetti della cultura cattolica nell'età di Leone XIII, Roma, Cinque Lune, 1961; S. Lanaro, Società e ideologie nel Veneto rurale (1866-1898), Roma, Edizioni di Storia e Letteratura, 1976; Id., Nazione e lavoro. Saggio sulla cultura borghese in Italia (1870-1925), Venezia, Marsilio, 1979; Elites e associazioni nell'Italia dell'Ottocento, in «Quaderni Storici», XXVI (1991), n. 2, pp. 357-541; F. Traniello, La cultura popolare cattolica nell'Italia unita, in S. Soldani, G. Turi (edd.), Fare gli italiani. Scuola e cultura nell'Italia contemporanea. I - La nascita dello Stato nazionale, Bologna, Il Mulino, 1993, pp. 429-458; G. Verucci, L'Italia laica prima e dopo l'Unità 1848-1876, Roma-Bari, Laterza, $1996^{2}$.

134 Cfr. G. Montroni, La famiglia borghese, in P. Melograni (a cura di), La famiglia italiana dall'Ottocento a oggi, Roma-Bari, Laterza, 1988, pp. 107-139. Ma si vedano anche G. Baglioni, L'ideologia della borghesia industriale nell'Italia liberale, Torino, Einaudi, 1974; e A.M. Banti, Storia della borghesia italiana. L'età liberale, Roma, Donzelli, 1996. Per un quadro complessivo delle scelte operate dopo l'unificazione nazionale dalle élites borghesi si veda infine R. Romanelli, L'Italia liberale 1861-1900, Bologna Il Mulino, 1990, specie le pp. 117-162. 
rappresentazione simbolica dell'infanzia), sembrerebbe prevalere una lettura che considera poco o nulla rilevante l'apporto specifico della Chiesa, al punto da attribuire alla sua presenza/iniziativa un significato marginale, episodico, non determinante comunque ai fini della delineazione del quadro generale. La quale cosa, sul piano propriamente storiografico, appare francamente semplicistica e riduttiva.

Ma sull'opportunità di un approfondimento della funzione e delle iniziative della Chiesa e del cattolicesimo nel suo insieme ai fini della messa a punto di un quadro più articolato e convincente della storia dell'infanzia e della sua educazione tra Otto e Novecento tornerò fra poco. Mi sembra ora necessario porre l'accento su un'altra importante questione evidenziata dalla storiografia degli ultimi decenni: intendo riferirmi al tentativo dei ceti dominanti, nell'Italia liberale e giolittiana (e più tardi fascista), di affermare, universalizzandola, una determinata «identità e immagine culturale dell'infanzia»135, ovvero di costituire una sorta di «dominio borghese sull'infanzia», attraverso l'imposizione di una ideologia/pedagogia del bambino che rinvia al più generale disegno borghese di egemonia culturale e di controllo ideologico e politico sulla società ${ }^{136}$.

Occorre domandarsi: perché il modello borghese, nonostante le aspirazioni egemoniche coltivate dai ceti dominanti, non è riuscito nel corso dell'Ottocento, ma anche per buona parte del secolo successivo, ad universalizzarsi, a permeare i costumi e le pratiche educative nei riguardi dell'infanzia e ad incidere in maniera decisiva sullo stesso «immaginario collettivo», ossia sulle rappresentazioni culturali del bambino?

La spiegazione fornita da Gaetano Bonetta, secondo cui «la mancata borghesizzazione, quanto meno ideologica, dell'universo infantile» rappresenterebbe il riflesso del più generale fallimento del «progetto politico di estensione totale del sistema sociale, economico e politico di tipo borghese» ${ }^{137}$, ha certamente una sua fondatezza, ma non aiuta molto a capire.

Per comprendere le ragioni di tale fallimento è necessario, a mio avviso, prendere in esame quelli che sono stati i "luoghi", gli strumenti e le modalità attraverso i quali, in particolare nella seconda metà dell'Ottocento, si è cercato di porre in atto, da parte dei ceti dominanti, quel «dominio borghese sull'infanzia» evidenziato dalla storiografia degli ultimi decenni:

- La scuola, innanzi tutto, come luogo di trasmissione del sapere, ma anche di determinati valori e modelli culturali;

- La letteratura per l'infanzia e i libri di testo, come pure - sul piano della formazione di un determinato «sentimento dell'infanzia» del mondo adulto - la grande narrativa e il «romanzo borghese» dell'Ottocento;

- La riflessione pedagogica, in particolare quella d'impostazione scientificopositivistica;

${ }^{135}$ Cfr. G. Bonetta, Storia e storiografia alla ricerca delle infanzie reali, in M.C. Giuntella, I. Nardi (edd.), Il bambino nella storia, cit., pp. 40-41.

${ }^{136} \mathrm{Si}$ veda in proposito F. Cambi, S. Ulivieri, Storia dell'infanzia nell'Italia liberale, cit., p. 17 e ss. 47).

${ }^{137}$ G. Bonetta, Storia e storiografia alla ricerca delle infanzie reali, cit., p. 41 (ma vedi anche le pp. 44- 
- I nuovi «saperi scientifici» sull'infanzia, che nell'Italia liberale e giolittiana assumono uno specifico rilievo sociale (pediatria, igiene infantile, psicologia dell'età evolutiva, psicoanalisi ecc.);

- La famiglia, oggetto di particolare attenzione da parte di pedagogisti, medici, scrittori per l'infanzia.

La scuola - Che alla scuola, alla scuola elementare e popolare in primo luogo, sia stato attribuito dalle élites liberali il compito di promuovere, insieme all'alfabetizzazione e all'istruzione di base, anche il sentimento dell'appartenenza nazionale e l'unificazione culturale e civile delle popolazioni attorno a determinati princìpi e valori borghesi è certamente un fatto noto ${ }^{138}$. Altrettanto noto, mi sembra, è il fatto che l'istituzione scolastica non sia realmente riuscita, almeno fino ai primi decenni del XX secolo, a connotarsi come luogo formativo capace di fare da cinghia di trasmissione, all'interno delle classi popolari urbane e rurali, dei valori e dei modelli culturali ed educativi del ceto dominante ${ }^{139}$; a divenire, cioè, lo spazio e il luogo privilegiato di quel processo di «borghesizzazione» della società italiana cui faceva riferimento Gaetano Bonetta.

E ciò, si badi, non solamente per i problemi e le carenze di tipo strutturale, ossia quelli relativi all'insufficiente distribuzione delle scuole sul territorio, ai bassi (talora bassissimi) indici di scolarizzazione e, per contro, alle elevate percentuali di abbandono, di mortalità scolastica, di evasione dall'obbligo riscontrati in tante zone della penisola (il Meridione, le aree agricole e montane ecc.)140; ma anche, e soprattutto, per lo scarto che è dato di registrare in questa scuola tra la pedagogia ufficiale, calata dall'alto (regolamenti, programmi, direttive ministeriali ecc.), e la pratica scolastica vera e propria.

A fornire originali ed importanti elementi alla conoscenza delle caratteristiche e dimensioni di questo scarto ha contribuito l'indagine a vasto raggio sulle riviste scolastiche e magistrali italiane dell'Otto e del Novecento promossa e coordinata, alcuni decenni fa, da Giorgio Chiosso, nell'ambito della quale sono stati pubblicati due ampi repertori della stampa periodica scolastica ed educativa dell'Otto e del Novecento e due organiche raccolte di studi fondati su un'imponente documentazione archivistica e a stampa ${ }^{141}$. Quali sono le indicazioni più significative emerse da tale ricerca?

- innanzi tutto, l'esistenza di uno scollamento profondo tra le elaborazioni della pedagogia scientifico-accademica e l'universo scolastico (educazione infantile negli asili e

${ }^{138}$ Cfr. A. Asor Rosa, Dall'Unità a oggi: la cultura, in R. Romano, C. Vivanti (edd.), Storia d'Italia, Torino, Einaudi, 1975, IV/2, pp. 841 ss.; e soprattutto la stimolante analisi proposta da G. Chiosso, La questione scolastica in Italia: l'istruzione popolare, in R. Lill, F. Traniello (edd.), Il «Kulturkampf» in Italia e nei paesi di lingua tedesca, Bologna, Il Mulino, 1992, pp. 335-388.

${ }^{139}$ Cfr. M. Raicich, Scuola e politica da De Sanctis a Gentile, Pisa, Nistri-Lischi, 1982, passim. Sul riemergere, al principio del XX secolo, della questione dell'«educazione nazionale» si veda G. Chiosso, L'educazione nazionale da Giolitti al primo dopoguerra, Brescia, La Scuola, 1983.

${ }^{140}$ Cfr. M. Barbagli, Disoccupazione intellettuale e sistema scolastico in Italia (1859-1973), Bologna, Il Mulino, 1974, passim; e la documentata ed efficace analisi proposta da G. Vigo, Gli italiani alla conquista dell'alfabeto, in S. Soldani, G. Turi (edd.), Fare gli italiani, cit., pp. 37-66.

${ }^{141}$ Cfr. G. Chiosso (ed.), I periodici scolastici nell'Italia del secondo Ottocento, Brescia, La Scuola, 1992; G. Chiosso (ed.), Scuola e stampa nel Risorgimento. Giornali e riviste per l'educazione prima dell'Unità, Milano, FrancoAngeli, 1989; G. Chiosso, (ed.), Scuola e stampa nell'Italia liberale. Giornali e riviste per l'educazione dall'Unità a fine secolo, Brescia, La Scuola, 1993; G. Chiosso (ed.), La stampa pedagogica e scolastica in Italia 1820-1943, Brescia, La Scuola, 1997. 
istruzione elementare e popolare): basterebbe verificare le idee e i modelli educativi per l'infanzia e la fanciullezza che circolano nella stampa periodica destinata alle istitutrici e maestre d'asilo o nelle riviste didattiche per gli insegnanti elementari ${ }^{142}$;

- in secondo luogo, il prevalere, lungo tutto il corso dell'Ottocento, di una concezione localistica dei problemi scolastici e la sostanziale mancanza di una visione "nazionale" del proprio ruolo e della propria funzione da parte degli stessi maestri, tanto da avvalorare l'ipotesi - che mi sembra largamente condivisibile - della nascita del "maestro italiano" solo sul finire del secolo ${ }^{143}$.

- in ultimo, la scarsa identificazione degli insegnanti elementari con gli ideali nazionali e patriottici e la loro sostanziale estraneità rispetto ai progressi della cultura e della scienza "borghesi"" incidere sulle pratiche educative e sugli ordinamenti scolastici soprattutto a partire dall'ultimo ventennio dell'Ottocento - ebbe una ricezione molto parziale nella concreta realtà scolastica e tra i maestri (si pensi alle vivaci polemiche e resistenze incontrate, al loro apparire, dai programmi Gabelli del 1888) ${ }^{145}$.

Alla luce di tali risultati, l'ipotesi formulata da Gaetano Bonetta, secondo cui il «fallimento» del tentativo della classe dirigente liberale di promuovere «l'espansione ideologica del modello infantile borghese» attraverso la scuola («in particolare la scuola dell'infanzia e quella dell'obbligo o primaria elementare») sarebbe da attribuire essenzialmente alla «incongruenza fra offerta educativa e pedagogica e domanda reale di educazione infantile», mi sembra suggestiva ma non adeguatamente suffragata, specie se si

${ }^{142}$ Cfr. R.S. Di Pol, La stampa per le maestre, in G. Chiosso (ed.), Scuola e stampa nell'Italia liberale, cit., 191-221. Un'attenta analisi delle "sfasature" esistenti tra «la cultura pedagogica e didattica e la scuola militante», che si snoda peraltro su un arco di tempo più lungo di quello qui considerato, è proposta in R. Fornaca, La pedagogia e la didattica per la scuola e nella scuola, in G. Cives (ed.), La scuola italiana dall'Unità ai nostri giorni, Firenze, La Nuova Italia, 1990, pp. 323-333.

${ }^{143}$ Cfr. G. Chiosso, La questione scolastica in Italia: l'istruzione popolare, cit., specie le pp. 384-388. Una significativa conferma di tale ipotesi emerge dalla lettura del fondamentale lavoro di A. Barausse, L'Unione Magistrale Nazionale dalle origini al fascismo (1901-1925), Brescia, La Scuola, 2002.

${ }^{144}$ Sulle difficoltà di penetrazione, nella scuola popolare e tra i maestri elementari, dei «valori politici e ideologici che avevano guidato il movimento nazionale e unitario» si vedano le osservazioni formulate nell'importante lavoro di G. Verucci, L'Italia laica prima e dopo l'Unità 1848-1876, Roma-Bari, Laterza, $1996^{2}$, p. 138 e ss.; cfr. anche gli spunti offerti in S. Lanaro, Nazione e lavoro. Saggio sulla cultura borghese in Italia 1870-1925, Venezia, Marsilio, 1979. Per un confronto sul ruolo e sulla funzione ideologico-politica rivestiti, nell'Ottocento, dagli insegnanti primari in Francia e in Germania si vedano: J. Ozouf (ed.), Nous, les maîtres d'école. Autobiographies d'instituteurs de la Belle Epoque, Paris, Gallimard, 1967; M. Ozouf, L'école, l'église et la République (1871-1914), Paris, Editions du Seuil, 1982; e A.J. La Vopa, Prussian Schoolteachers: profession and office 1763-1848, Chapel Hill, University of North Carolina Press, 1980.

${ }^{145} \mathrm{Si}$ vedano in proposito le acute osservazioni formulate in G. Chiosso, Giornali e giornalisti per la scuola nel secondo Ottocento, in G. Chiosso (ed.), I periodici scolastici del secondo Ottocento, cit., pp. 4044. Cfr. anche R. Fornaca, La scuola italiana e il positivismo, in E.R. Papa (ed.), Il positivismo e la cultura italiana, Milano, Franco Angeli, 1985, pp. 335-349. Sul tipo di accoglienza riservato dalla «scuola militante» ai programmi Gabelli del 1888 si vedano, ad esempio, le valutazioni formulate su testate quali: «Il Corriere scolastico» (Roma, 1887-1902), «La Guida del maestro elementare italiano» (Torino, 1864-1897), «La Lega degli insegnanti elementari» (Cuneo, 1886-1905), «Il Raccoglitore scolastico» (Trieste, 1893-1895), «Il Rinnovamento scolastico» (Roma, 1892-1899), la «Rivista della Pubblica Istruzione» (Roma, 1887-1911), «La Scuola popolare» (Palermo, 1886-1895). Cfr. anche E. Catarsi, Storia dei programmi della scuola elementare (1860-1985), cit., p. 43. 
presuppone l'esistenza di una consapevole e ben definita «domanda di educazione infantile» da parte delle classi popolari.

E’ vero tuttavia che, se la scuola rappresentò «il luogo privilegiato e scientificamente idoneo» di trasmissione del modello infantile borghese nella società italiana del secondo Ottocento146, occorre prendere atto che un simile processo - dato un po' per scontato in tante ricostruzioni di storia dell'infanzia e della sua educazione - fu ben lungi dal realizzarsi, almeno per quanto riguarda l'Ottocento.

La letteratura per l'infanzia e i libri di testo - E' questo un ambito di ricerca che deve essere ancora ampiamente coltivato, ma sul quale disponiamo già di contributi di un certo interesse. Basterebbe qui far cenno agli studi di Antonio Faeti e del gruppo di ricerca bolognese, nonché ai lavori di Pino Boero e Carmine De Luca e, più recentemente, di Renata Lollo, Mariella Colin, Anna Ascenzi, Sabrina Fava e Davide Montino ${ }^{147}$. Di grande interesse, si rivelano anche le pregevoli e documentate analisi offerte da storici dell'età contemporanea e da studiosi della letteratura e della cultura, quali Alberto Asor Rosa, Guido Verucci, Silvio Lanaro e Antonio Gibelli ${ }^{148}$.

\footnotetext{
${ }^{146}$ G. Bonetta, Storia e storiografia alla ricerca delle infanzie reali, cit., pp. 43-45.

${ }^{147}$ A. Faeti, Guardare le figure, Torino, Einaudi, 1972; Id., Letteratura per l'infanzia, Firenze, La Nuova Italia, 1977; E. Beseghi (ed.), La scala a chiocciola. Paura, horror, finzioni: dal romanzo gotico a Dylan Dog, Scandicci (Firenze), La Nuova Italia, 1993; Ead. (ed.), Infanzia e racconto. Il libro, le figure, la voce, lo sguardo, Bologna, Bononia University Press, 2003 (ma si vedano anche i diversi contributi editi nella collana di Mondadori «L'isola misteriosa. Quaderni di letteratura per l'infanzia», diretta dalla stessa Emy Beseghi); P. Boero, C. De Luca, Letteratura per l'infanzia, Roma-Bari, Laterza, 1995; P. Boero, Una storia, tante storie. Guida all'opera di Gianni Rodari, Torino, Einaudi, 1992 (nuova edizione: Torino, Einaudi, 2010); Id., Alla frontiera. Momenti, generi e temi della letteratura per l'infanzia, Trieste, Einaudi, 1997; R. Lollo, Sulla letteratura per l'infanzia, Brescia, La Scuola, 2003; Ead. (ed.), Il «Corriere dei piccoli» in un secolo di riviste per ragazzi, Milano, Vita e Pensiero, 2009M. Colin, L'age d'or de la littérature d'enfance et de jeunesse italienne: des origines au fascisme, Caen, Presses Universitaires de Caen, 2005; Ead., "Les enfants de Mussolini». Littérature, livres, lectures d'enfance et de jeunesse. De la Grande Guerre à la chute du régime, Caen, Presses Universitaires de Caen, 2010; A. Ascenzi, La storia della letteratura per l'infanzia oggi. Prospettive metodologiche e itinerari di ricerca, in Ead. (ed.), La letteratura per l'infanzia oggi, Milano, Vita e Pensiero, 2003, pp. 109-120; Ead., "Per educare la gioventù della nuova Italia». Luigi Bertelli giornalista e scrittore per l'infanzia tra eredità risorgimentale e costruzione di una nuova coscienza etico-civile (1860-1920), in A. Ascenzi, M. Di Felice, R. Tumino (a cura di), «Santa Giovinezza!». Lettere di Luigi Bertelli e dei suoi corrispondenti (1883-1920), Macerata, Alfabetica Edizioni, 2008, pp. 13-43; Ead., Il Plutarco delle donne. Repertorio della pubblicistica educativa e scolastica e della letteratura amena destinata al mondo femminile nell'Italia dell'Ottocento, Macerata, EUM, 2009; S. Fava, Emilia Formíggini Santamaria. Dagli studi storico-pedagogici alla letteratura per l'infanzia, Brescia, La Scuola, 2002; Ead., Dal «Corriere dei Piccoli». Giana Anguissola scrittrice per ragazzi, Milano, Vita e Pensiero, 2009 ; D. Montino, Libri e giovani lettori tra XIX e XX secolo: un percorso di tipo qualitativo, «History of Education \& Children's Literature», II (2007), 1, pp. 299-322; Id., Le tre Italie di Giuseppe Fanciulli. Educazione e letteratura infantile nel primo Novecento, Torino, SEI, 2009; Id., Giuseppe Fanciulli negli anni de «Il Giornalino della Domenica». Infanzia, giornalismo e politica, «History of Education \& Children's Literature», VI (2011), 1, pp. 305-317; e Id., Società, infanzia e narrazioni realistiche nella letteratura giovanile dell'Italia del secondo dopoguerra (1946-1962), «History of Education \& Children's Literature», VII (2012), 2, pp. 287-318.

${ }^{148}$ A. Asor Rosa, Dall'Unità a oggi: la cultura, in R. Romano, C. Vivanti (edd.), Storia d'Italia, Torino, Einaudi, 1975, IV/2, pp. 822-1311; G. Verucci, L'Italia laica prima e dopo l'Unità 1848-1876, cit., pp. 65178; S. Lanaro, Il Plutarco italiano: l'istruzione del "popolo" dopo l'Unità, in C. Vivanti (ed.), Storia d'Italia. Annali 4: Intellettuali e potere, Torino, Einaudi, 1981, pp. 553-587; Id., Nazione e lavoro. Saggio sulla cultura borghese in Italia 1870-1925, cit.; A. Gibelli, Il popolo bambino. Infanzia e nazione dalla Grande Guerra a Salò, Torino, Einaudi, 2005.
} 
Per quel che concerne $\mathrm{i}$ testi scolastici, oltre all'ormai datato ma ancora fondamentale lavoro di Marcella Bacigalupi e Piero Fossati sui libri di lettura per le scuole elementari dell'Italia unita ${ }^{149}$, debbono essere segnalati i fondamentali lavori dati alle stampe negli ultimi due decenni dal gruppo di ricerca coordinato da Giorgio Chiosso e Roberto Sani ${ }^{150}$.

Da queste e da altre ricerche sulle quali non è possibile soffermarsi, emerge chiaramente la peculiare funzione rivestita da una simile pubblicistica nella trasmissione/veicolazione dei valori, degli stili di vita, degli indirizzi e modelli educativi, dello stesso «immaginario» sull'infanzia, caratteristici dei ceti borghesi dominanti. «Per quanto riguarda l'Italia - ha notato ad esempio Franco Cambi - non sarà poi un caso che tale tipo di letteratura veda proprio nel corso dell'Ottocento, $[\ldots]$ soprattutto nella seconda metà del secolo, la sua piena fioritura, giusto nel momento in cui viene a costituirsi (pur tra lacune e arretratezze) un ceto borghese, il quale si afferma, in ogni direzione, dal politico al privato, con una precisa volontà di governo»» ${ }^{151}$.

L'impressione di fondo tuttavia è che, al di là del suo valore intrinseco, la diffusione di tale pubblicistica sia stata, almeno fino alla fine del secolo, assai più contenuta e circoscritta di quanto, a prima vista, si potrebbe supporre. Se si tengono presenti le misere

${ }^{149}$ M. Bacigalupi, P. Fossati, Da plebe a popolo. L'educazione popolare nei libri di scuola dall'Unità d'Italia alla repubblica, Firenze, La Nuova Italia, 1986.

${ }^{150}$ G. Chiosso, Editoria e stampa scolastica tra Otto e Novecento, in L. Pazzaglia (ed.), Cattolici, educazione e trasformazioni socio-culturali in Italia tra Otto e Novecento, Brescia, La Scuola, 1999, pp. 499527; Id. (ed.), Il libro per la scuola tra Sette e Ottocento, Brescia, La Scuola, 2000; Id. (ed.), TESEO. Tipografi e editori scolastico-educativi dell'Ottocento, Milano, Editrice Bibliografica, 2003; Id., L'editoria scolastica prima e dopo la riforma Gentile, «Contemporanea», 7 (2004), 3, pp. 411-434; Id., Il rinnovamento del libro scolastico nelle esperienze di Giuseppe Lombardo Radice e dei "lombardiani», «History of Education \& Children's Literature», I (2006), 1, pp. 127-139; Id. (ed.), TESEO '900. Editori scolasticoeducativi del primo Novecento, Milano, Editrice Bibliografica, 2008; A. Ascenzi, R. Sani (edd.), Il libro per la scuola tra idealismo e fascismo. L'opera della Commissione centrale per l'esame dei libri di testo da Giuseppe Lombardo Radice ad Alessandro Melchiori (1923-1928), Milano, Vita e Pensiero, 2005; A. Barausse, L'editoria scolastico-educativa nell'Italia Meridionale del primo Novecento: il caso del Molise (1900-1943), in Tipografia e editoria in Abruzzo e Molise. Il XX secolo, Soveria Mannelli, Rubbettino, 2007, pp. 211-261; F. Targhetta, La capitale dell'impero di carta. Editori per la scuola a Torino nella prima metà del Novecento, Torino, SEI, 2007; Id., Serenant e illuminant. I cento anni della SEI, Torino, SEI, 2008 ; A. Barausse (ed.), Il libro per la scuola dall'Unità al fascismo. La normativa sui libri di testo dalla legge Casati alla riforma Gentile (1861-1922), Macerata, Alfabetica Edizioni, 2008, 2 voll.; M. D’Alessio, Scuola e lingua nel Molise di fine Ottocento, Napoli, Edizioni Scientifiche Italiane, 2005; A. Ascenzi, R. Sani (edd.), Il libro per la scuola nel ventennio fascista. La normativa sui libri di testo dalla riforma Gentile alla fine della seconda guerra mondiale (1923-1945), Macerata, Alfabetica Edizioni, 2009; A. Barausse, Dal Regno di Sardegna al Regno d'Italia. Continuità e discontinuità nelle politiche del libro scolastico, "History of Education \& Children's Literature», V (2010), 1, pp. 377-415; V (2010), 2, pp. 301-338; A. Ascenzi, «Per impedire l'intrusione nell'istruzione nazionale del seme di mala scienza e di mali costumi». La relazione di Luigi Gabriele Pessina sull'esame dei libri di testo (1881), «History of Education \& Children's Literature», V (2010), 2, pp. 339-381; M.C. Morandini, I manuali per l'educazione dei sordomuti: $i$ testi di lingua e di istruzione religiosa, in P. Bianchini (a cura di), Le origini delle materie. Discipline, programmi e manuali scolastici in Italia, Torino, SEI, 2010, pp. 139-165; D. Montino, La storia nei libri scolastici elementari del dopoguerra, ivi, pp. 217-246; i contributi relativi all'editoria scolastica e ai libri di testo raccolti in R. Sani, Sub specie educationis. Studi e ricerche su istruzione, istituzioni scolastiche e processi culturali e formativi nell'Italia contemporanea, Macerata, EUM, 2011; e il recente G. Chiosso, Libri di scuola e mercato editoriale. Dal primo Ottocento alla Riforma Gentile, Milano, Franco Angeli, 2013.

${ }^{151}$ F. Cambi, S. Ulivieri, Storia dell'infanzia nell'Italia liberale, cit., p. 28. 
condizioni in cui versava l'istruzione popolare nelle zone rurali ${ }^{152}$ e le difficoltà oggettive incontrate, anche dopo l'emanazione della legge Coppino (1877), dai processi di alfabetizzazione e di scolarizzazione primaria nelle campagne e in tante parti dell'Italia centro-meridionale $^{153}$, non è esagerato ipotizzare che la circolazione dei libri di testo e della stessa letteratura per l'infanzia e per la gioventù abbia riguardato soprattutto i centri urbani e le aree più alfabetizzate della penisola ed interessato prevalentemente i ceti benestanti e gli strati superiori della popolazione artigiana e operaia ${ }^{154}$.

Tale ipotesi, del resto, sembra trovare parziale conferma nelle reiterate denunce circa la carenza di buone letture e di libri espressamente destinati all'infanzia e alla gioventù povera delle aree rurali formulate, specie negli anni Settanta e Ottanta dell'Ottocento, da educatori e associazioni filantropiche impegnati nel campo dell'istruzione ed educazione popolare ${ }^{155}$.

I nuovi «saperi scientifici» sull'infanzia - Sulla scia delle fondamentali ricerche di Michel Foucault in ordine al rapporto tra scienza, ideologie dominanti e controllo sociale $^{156}$, come pure dei recenti studi avviati in Italia sull'evoluzione della medicina e delle scienze umane nella seconda metà dell'Ottocento ${ }^{157}$, la ricerca storico-pedagogica ha

152 Cfr. T. Tomasi, Da Matteucci a Corradini. Le inchieste sulla scuola popolare nell'età liberale, in C.I.R.S.E., Problemi e momenti di storia della scuola e dell'educazione, Pisa, ETS, 1982, pp. 117-143, la quale, sulla scorta dei risultati delle inchieste ministeriali, osserva tra l'altro: «Neppure l'inchiesta 1868-1872 giunge a risultati confortanti per quanto riguarda il profitto; ovunque, sia pure con notevoli disuguaglianze tra nord e sud, città e campagna, risulta molto basso a causa dell'elevato numero di alunni, dei locali assolutamente inadatti, dell'assenza e deficienza degli strumenti indispensabili a cominciare dai libri. [...] Difficoltà anche peggiori s'incontrano nel Meridione dove l'istruzione elementare, considerata un privilegio di classe, continuava a restare estranea alle 'misere plebi'. [...] Secondo l'inchiesta Ravà (1897-1898), che dà largo spazio a contenuti e metodi, $[. .$.$] un autentico rinnovamento è sempre ostacolato [...] dalla povertà dei$ sussidi didattici» (pp. 136-137).

${ }^{153} \mathrm{Si}$ vedano al riguardo G. Talamo, Istruzione obbligatoria ed estensione del suffragio, in Stato e società dal 1876 al 1882. Atti del XLIX Congresso di Storia del Risorgimento Italiano, Roma, Istituto per la Storia del Risorgimento Italiano, 1980, pp. 57-110; e G. Vigo, «Quando il popolo cominciò a leggere». Per una storia dell'alfabetismo in Italia, in «Società e Storia», VI (1983), n. 22, pp. 803-828.

${ }_{154}$ Sulla diffusione della lettura tra le classi popolari urbane nel secondo Ottocento si vedano: S. Pivato, Movimento operaio e istruzione popolare nell'Italia liberale. Discussioni e ricerche, Milano, Franco Angeli, 1986, pp. 17-88; G. Barone, A. Petrucci, Primo: non leggere. Biblioteche e pubblica lettura in Italia dal 1861 ai nostri giorni, Milano, Mazzotta, 1976, pp. 33-49. Sulla funzione esercitata in tale ambito dalle Società operaie di mutuo soccorso e dalle Leghe per l'istruzione del popolo si veda, infine, G. Verucci, L'Italia laica prima e dopo l'Unità 1848-1876, cit., pp. 81-112.

155 Tale situazione, ad esempio, era sottolineata a più riprese da Ottavio Gigli, segretario dell'Associazione Nazionale degli Asili Rurali per l'Infanzia, un sodalizio sorto a Firenze nel 1866 per promuovere l'educazione infantile e l'istruzione popolare nelle campagne, il quale annoverava tra $\mathrm{i}$ suoi promotori e animatori Niccolò Tommaseo, Gino Capponi, Bettino Ricasoli, Carlo Matteucci, che ne fu il primo presidente, e Terenzio Mamiani, che ne assunse la presidenza dopo la morte del Matteucci. Si veda al riguardo A. Ascenzi, R. Sani, «Moulding the peasant masses to make our Italy into a Nation». Ottavio Gigli and the National Association for the Founding of Rural Infant Schools, from the struggle against illiteracy to nation-building (1866-1873), in «History of Education \& Children's Literature», VIII (2013), n. 2, pp. 159194; IX (2014), n. 1, pp. 388-450.

${ }^{156} \mathrm{Si}$ vedano, in particolare, M. Foucault, Le parole e le cose. Un'archeologia delle scienze umane, trad. it., Milano, Rizzoli, 1967; Id., Nascita della clinica. Il ruolo della medicina nella costituzione delle scienze umane, trad. it., Torino, Einaudi, 1969; Id., Sorvegliare e punire. La nascita della prigione, trad. it., Torino, Einaudi, 1976.

${ }^{157} \mathrm{Si}$ vedano soprattutto G. Cosmacini, Medicina, ideologia, filosofia nel pensiero dei clinici, in C. Vivanti (ed.), Storia d'Italia Annali, 4. Intellettuali e potere, Torino, Einaudi, 1981; Id., Storia della medicina 
dedicato crescente attenzione al ruolo esercitato dai nuovi «saperi scientifici» nella determinazione/diffusione di specifiche forme di controllo del corpo e di regolamentazione degli atteggiamenti e dei comportamenti infantili modellate sui principi dell'etica e dell'ideologia borghese dominante.

La valorizzazione della ginnastica (si pensi, ad esempio, al vivace dibattito sviluppatosi in questa fase sul significato e sugli obiettivi dell'educazione fisica

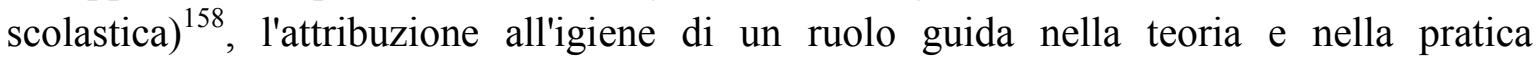
educative, l'avvio di una vera e propria medicalizzazione dell'infanzia, con la conseguente ridefinizione della pedagogia infantile come clinica dello sviluppo corporeo e psichico del bambino $^{159}$, rappresentano i diversi aspetti del processo volto a determinare quella che Franco Cambi ha definito «una specifica frontiera del dominio borghese sull'infanzia» ${ }^{160}$.

Anche in questo caso, tuttavia, si ha l'impressione che la cosiddetta «scienza borghese», alla cui espansione e circolazione dovevano fornire un contributo determinante tanto la scuola ${ }^{161}$ quanto una vasta pubblicistica d'intonazione popolare ( $\mathrm{ma}$ in realtà destinata a trovare i suoi principali referenti nella piccola borghesia e nelle fasce superiori del proletariato industriale dei grandi centri urbani) espressamente dedicata alla divulgazione scientifica ${ }^{162}$, non sia riuscita, almeno per tutto l'Ottocento, a trasformarsi in «sapere di massa», ossia ad esercitare un reale e sistematico influsso sulla mentalità, sui costumi, sullo stesso "vissuto" individuale e collettivo dei ceti urbani meno abbienti e, in particolare, delle popolazioni contadine.

$\mathrm{Si}$ tratta allora di individuare quali saperi, quali modelli, quali concezioni dell'infanzia e della sua educazione "diversi", se non addirittura "alternativi", rispetto a quelli borghesi dominanti, hanno realmente informato i comportamenti e le pratiche in

e della sanità in Italia, Roma-Bari, Laterza, 1987; R. Viale, Medicina e positivismo, in E.R. Papa (ed.), Il positivismo e la cultura italiana, cit., pp. 412 ss.; e i diversi contributi pubblicati in F. Della Peruta (ed.), Storia d'Italia, Annali, 7. Malattia e medicina, Torino, Einaudi, 1984.

${ }^{158} \mathrm{Su}$ tale tematica si veda in particolare il volume di G. Bonetta, Corpo e nazione. L'educazione ginnastica, igienica e sessuale nell'Italia liberale, Milano, Franco Angeli, 1990.

159 «Tutto sommato - scriveva qualche anno fa Egle Becchi -, è il corpo infantile il grande centro, positivo e negativo, della vicenda dell'infanzia nell'Ottocento. Un corpo curato e trascurato, ma anche e soprattutto un 'corpo raddrizzato', un corpo pregiato, ma anche disciplinato fino alla mortificazione, un corpo esercitato e fatto crescere con cure e supporti. Non vanno dimenticati infatti - e si iscrivono in una pedagogia tipicamente ottocentesca che è prevalentemente ortopedia - tutte le protesi che servono alla fisicità del bambino» (E. Becchi, L'Ottocento, in E. Becchi, D. Julia (a cura di), Storia dell'infanzia. 2. Dal Settecento a oggi, cit., p. 153).

${ }^{160}$ F. Cambi, S. Ulivieri, Storia dell'infanzia nell'Italia liberale, cit., p. 9. Ma si vedano, in particolare, le osservazioni formulate dallo stesso Cambi nel cap. II: «I medici-igienisti e l'infanzia: controllo del corpo e ideologia borghese» (ivi, pp. 53-80).

${ }^{161}$ Ibidem, pp. 61-66.

${ }^{162}$ A puro titolo esemplificativo ricordiamo le collane dell'Editore Sonzogno: «Biblioteca del popolo» (dal 1873), «L'igiene popolare» e «Biblioteca Universale» (dal 1882); e quelle dell'Editore Treves: «Biblioteca utile» (dal 1864) e «La Scienza del Popolo» (dal 1867). Si tengano anche presenti le numerosissime opere dello stesso genere apparse in collane non specifiche di editori diversi (U.T.E.T., Barbèra, Sandron ecc.) e, in particolare, quelle pubblicate nei famosi Manuali Hoepli. Tra i periodici: «L'Igea. Giornale d'igiene e medicina preventiva» (Milano, dal 1862), «La salute. Giornale d'igiene popolare» (Genova, dal 1864), «Igiene infantile» (Venezia, dal 1878), «L'igiene dell'infanzia e medicina preventiva» (Roma, dal 1892), «Igiene e Scuola» (Mantova, dal 1892). 
ordine alle differenti infanzie dell'Italia dell'Ottocento e dei primi decenni del nostro secolo.

La famiglia - La famiglia rappresenta un importante terreno di approfondimento e di verifica per lo storico dell'infanzia e della sua educazione, ma si configura indubbiamente come una realtà difficile da studiare, specie sotto il profilo delle strategie $\mathrm{e}$ delle pratiche formative ${ }^{163}$, non a caso quasi del tutto ignorate nei pur pregevoli studi di carattere storico-sociale apparsi negli ultimi decenni ${ }^{164}$.

C'è innanzi tutto un problema di fonti ${ }^{165}$, ma si pone anche la necessità di mettere a punto nuove metodologie d'indagine, specifiche griglie di lettura capaci di penetrare un universo culturale e sociale che appare ancora, sotto molti aspetti, sfuggente.

I tre modelli individuati dalle ricerche di carattere sociologico, e fatti propri da diversi storici dell'infanzia, ossia: la famiglia «borghese», quella «operaia-popolare urbana» e quella «contadina», aiutano poco a capire, offrono allo storico riferimenti tanto generali da sconfinare nel generico. Certo, si percepisce chiaramente, già da questa sommaria tipologia, che siamo di fronte a realtà molto diverse, con condizioni materiali di vita, forme di socializzazione, ma anche «immaginari collettivi», quadri di riferimento ideali, estremamente differenti. Il che, tuttavia, è ben lungi dall'esaurire il discorso. La stessa famiglia «borghese», ossia quella che si conosce - o si ritiene di conoscere - meglio, ad un'analisi un minimo più attenta e circostanziata presenta molteplici differenziazioni e sfaccettature $^{166}$.

Un solo esempio: la borghesia del Veneto post-unitario, legata ai moduli di un cattolicesimo culturalmente e politicamente conservatore, che, come ci hanno mostrato gli

${ }^{163}$ Cfr. R. Sani, For a History of Family Education in the Modern and Contemporary Era. Research Itineraries and Perspectives, in «History of Education \& Children's Literature», I (2006), n. 1, pp. 55-81.

${ }^{164}$ Con riferimento alla realtà italiana, si vedano: M. Barbagli, Sotto lo stesso tetto. Mutamenti della famiglia in Italia dal XV al XX secolo, Bologna, Il Mulino, 1984; Id., Provando e riprovando. Matrimonio, famiglia e divorzio in Italia e in altri paesi occidentali, Bologna, Il Mulino, 1990; P. Melograni (ed.), La famiglia italiana dall'Ottocento a oggi, Roma-Bari, Laterza, 1988; M. Barbagli, D.I. Kertzer (edd.), Storia della famiglia italiana 1750-1950, Bologna, Il Mulino, 1992; G. Campanini (ed.), Le stagioni della famiglia. La vita quotidiana nella storia d'Italia dall'unità agli anni Settanta, Cinisello Balsamo (Milano), San Paolo, 1994. Per quel che concerne lo scenario europeo ed extra-europeo, cfr.: C.E. Rosemberg (ed.), The Family in History, Philadelphia, The University of Pennsylvania Press. Inc., 1975; E. Shorter, The Making of the Modern Family, New York, Basic Book, 1975; M. Anderson, Approaches to the History of the Western Family 1500-1914, London, 1980; J. Goody, The Development of the Family and Marriage in Europe, Cambridge, Cambridge University Press, 1983; R. Wall, J. Robin, P. Laslett (edd.), Family Forms in Historic Europe, Cambridge, Cambridge University Press, 1983; F. Lebrun, La vie coniugale sous l'Ancien Régime, Paris, A. Colin, 1993.

${ }^{165}$ Cfr. G. Campanini, La storiografia della famiglia in Italia: Bilancio, problemi, prospettive, in Id. (ed.), Le stagioni della famiglia. La vita quotidiana nella storia d'Italia dall'unità agli anni Settanta, cit., pp. 15-37.

166 «La realtà - ha rilevato Giovanni Montroni, a proposito della «famiglia borghese» nell'Italia dell'Ottocento - è più complessa. [...] Ancora più difficile è parlare, anche a voler prescindere dalle borghesie imprenditoriali, di una famiglia borghese tout court. Sembra piuttosto necessario distinguere una serie di livelli e di funzioni borghesi ed una serie corrispondente di strutture e relazioni domestiche, senza dimenticare che le differenze regionali e le relazioni con il mondo agricolo contribuiscono a moltiplicare ulteriormente i sistemi familiari prevalenti. Delle lower middle classes o come oggi si usa dire, borghesie numerose, nonostante il riconoscimento unanime della loro importanza, non si sa però quasi nulla» (G. Montroni, La famiglia borghese, in P. Melograni (ed.), La famiglia italiana dall'Ottocento a oggi, cit. p. 112). 
studi di Gabriele De Rosa, Angelo Gambasin e Silvio Lanaro167, si raccoglie attorno alla parrocchia, è animata da un forte sentimento antiliberale e antistatalista, è ancorata ai valori religiosi e alle proprie radici contadine, ma, al tempo stesso, si mostra attenta e partecipe all'innovazione e allo sviluppo in campo economico e produttivo; questa borghesia, dicevo, si presenta come una realtà estremamente diversa rispetto ad altre borghesie della penisola.

Ora, il punto è questo: il suo "immaginario" sull'infanzia, la sua concezione dei figli e della loro cura ed educazione, le sue pratiche formative coincidevano con quelli propagandati dalla letteratura scientifica e pedagogica d'indirizzo positivistico? Mi sembra quanto meno un aspetto da verificare. Ma il discorso potrebbe estendersi anche ad altre aree e ad altri gruppi sociali.

Per venire alla famiglia «contadina» 168 , ho l'impressione che, se si vuole davvero comprendere una realtà così complessa e caratteristica, è necessario da parte degli storici dell'infanzia ampliare i riferimenti culturali di carattere generale. Sorprende non poco, ad esempio, il fatto che i pochi studiosi che si sono occupati dell'infanzia contadina nell'Italia dell'Otto e del Novecento abbiano attinto, esclusivamente o quasi, agli studi di Ernesto De Martino, Vittorio Lanternari, Luigi M. Lombardi Satriani ed altri, ossia a ricerche di carattere antropologico ed etnologico, a indagini sul folklore, ignorando del tutto il fondamentale - e a mio avviso imprescindibile - apporto recato alla conoscenza della realtà contadina degli ultimi due secoli nel nostro paese dalla storiografia sociale e religiosa169.

Le campagne - quelle settentrionali e, con modalità e ritmi differenti, quelle del Centro-Sud - videro svilupparsi, nel secondo Ottocento, un forte e radicato movimento sociale cattolico, raccolto attorno ai vescovi e ai parroci: un movimento che si alimentava dei valori solidaristici e cooperativi propri della dottrina sociale cristiana, e che si rese protagonista di una vasta opera di modernizzazione sul terreno economico e sociale e della

${ }^{167}$ Cfr. G. De Rosa, Mentalità e mutamenti economici nella società veneta, in A. Lazzarini (ed.), Trasformazioni economiche e sociali nel veneto fra XIX e XX secolo, Vicenza, Istituto per le ricerche di storia sociale e di storia religiosa, 1984, pp. 13-36; G. Gambasin, Mentalità parrocchiale e centri urbani nel Veneto alla fine dell'Ottocento, in «Ricerche di storia sociale e religiosa», I (1972), n. 2, pp. 131-182; S. Lanaro, Movimento cattolico e sviluppo capitalistico nel Veneto fra '800 e' '900. Linee interpretative, in Movimento cattolico e sviluppo capitalistico, in «Studi Storici», XV (1974), n. 1, pp. 11-51.

${ }^{168}$ Ma sarebbe forse più opportuno parlare di diverse tipologie familiari del mondo contadino e della società agricola nel suo complesso. Cfr. M. Barbagli, Sotto lo stesso tetto. Mutamenti della famiglia in Italia dal XV al XX secolo, cit., pp. 525-538.

169 A puro titolo esemplificativo ricordiamo: G. De Rosa, Vescovi, popolo e magia nel sud. Ricerche di storia socio-religiosa dal XVII al XIX secolo, Napoli, Guida, 1971; Id., Chiesa e religione popolare nel Mezzogiorno, Roma-Bari, Laterza, 1978; S. Lanaro, Società e ideologia nel Veneto rurale (1866-1898), Roma, Edizioni di Storia e Letteratura, 1976; A. Cestaro, Strutture ecclesiastiche e società nel Mezzogiorno, Napoli, Ferraro, 1978; A. Gambasin, Parroci e contadini nel Veneto alla fine dell'Ottocento, Roma, Edizioni di Storia e Letteratura, 1973; G. Rosoli (ed.), Chiesa ed emigrazione italiana tra '800 e '900, Roma, C.S.E.R., 1982; La società religiosa nell'età moderna Atti del Convegno Studi di storia sociale e religiosa ( CapaccioPaestum, 18-21 maggio 1972), Napoli, Guida, 1973. Sulle prospettive e gli indirizzi della storiografia socioreligiosa in Italia si vedano in particolare A. Lazzarini, Studi di storia socio-religiosa, in «Quaderni Storici», IX (1974), n. 26, pp. 568-581; e F. Salimbeni, Problemi e prospettive di storia socio-religiosa, in A. Cestaro (ed.), Studi di storia sociale e religiosa. Scritti in onore di Gabriele De Rosa, Napoli, Ferraro, 1980, pp. 155177. 
crescita di una più larga sensibilità civile e culturale tra le popolazioni agricole. Basterebbe richiamare la fitta rete di società di mutuo soccorso, cooperative di lavoro, casse rurali, istituzioni assistenziali ed educative che ebbero nella parrocchia il loro punto di riferimento ${ }^{170}$.

In questo ambito la Chiesa ha operato in profondità e ha operato sovente in funzione antiborghese (si pensi all'influsso dell'intransigentismo cattolico), alimentando e promuovendo una sensibilità etico-religiosa e una visione dell'uomo e della società profondamente diverse rispetto a quelle che ispiravano le élites borghesi dei grandi centri urbani $^{171}$.

Occorre approfondire - ed è questa, mi sembra, una ricerca ancora in larga parte da compiere - quanto la presenza così forte e radicata della Chiesa nelle diverse aree agricole del nostro Paese ha inciso sul piano dei modelli e delle pratiche educative per l'infanzia.

\section{Per un ampliamento dell'indagine storica sull'infanzia e sulla sua educazione in Italia tra Otto e Novecento: fonti e prospettive di ricerca}

Dalle osservazioni e dai rilievi sopra formulati emergono, mi sembra, due questioni d'indubbia importanza ai fini di una più puntuale indagine storica sull'infanzia e sulla sua educazione in Italia tra Otto e Novecento.

Innanzi tutto, si pone la necessità di un ampliamento delle fonti e dei materiali documentari su cui fondare le ricerche, come pure di un più organico e sistematico sfruttamento di fonti già note, ma solo parzialmente utilizzate. E' il caso, ad esempio, della letteratura per l'infanzia e dei libri di testo per la scuola elementare: un'indagine su tali preziosi materiali a stampa non può limitarsi alla pur indispensabile analisi testuae (contenuti, modelli, indirizzi formativi), ma deve necessariamente estendersi ad aspetti e motivi di notevole importanza per lo storico dell'infanzia, quali la diffusione (tirature, ristampe ecc.) e l'effettiva circolazione dei testi nei diversi contesti sociali e culturali, attraverso la verifica, ad esempio, dei cataloghi delle biblioteche scolastiche e popolari, di quelle circolanti rurali, degli elenchi delle opere acquistate dalle Società operaie di mutuo soccorso e dalle leghe per l'istruzione del popolo ${ }^{172}$.

L'altra questione concerne l'esigenza di approfondire, in modo più serio e sistematico di quanto si sia fatto finora, il ruolo esercitato dalla Chiesa nell'Italia dell'Otto e del Novecento sia sul piano della costruzione di una nuova "immagine" dell'infanzia, sia sul versante delle iniziative assistenziali ed educative specificamente rivolte al mondo infantile.

${ }^{170}$ Cfr. Archivio per la Storia del Movimento Sociale Cattolico in Italia, Mezzo secolo di ricerca storiografica sul movimento cattolico in Italia. Dal 1861 al 1945: contributo a una bibliografia, Brescia, La Scuola, 1995 (in particolare il saggio introduttivo di A. Canavero alle pp. 7-72).

${ }^{171} \mathrm{Si}$ vedano al riguardo le stimolanti osservazioni formulate qualche anno fa da F. Traniello, La cultura popolare cattolica nell'Italia unita, in S. Soldani, G. Turi (edd.), Fare gli italiani, cit., pp. 429-458.

${ }^{172}$ Cfr. A. Ascenzi, Children's literature as a "source" for the history of education and cultural processes. Toward an on-going assessment of studies conducted in Italy over last decade, in "History of Education \& Children's Literature», VII (2012), n. 2, pp. 79-96; Ead., La ricerca sulla manualistica scolastica in Italia: nuovi orientamenti storiografici e prospettive per il futuro, in J. Meda, A.M. Badanelli (edd.), La historia de la cultura escolar en Italia y en España: balance y perspectivas, Macerata, EUM, 2013, pp. 119-138. 


\section{1 - Fonti}

a) Una fonte ancora quasi completamente ignorata, almeno nel nostro paese, dagli storici dell'educazione e dell'infanzia è rappresentata dalla trattatistica minore destinata alla famiglia: intendo riferirmi alla gran messe di trattatelli, opuscoli, operette e altri scritti di stampo popolare destinati precipuamente ai padri e alle madri di famiglia e incentrati sulle tematiche della vita e dell'educazione familiare. Si tratta di un tipo di pubblicazioni di poche pretese, che annovera tra i suoi autori parroci, sacerdoti in cura d'anime, religiosi, più raramente esponenti del laicato cattolico, e che si rivolge a un pubblico di lettori molto variegato (contadini, artigiani, impiegati, commercianti), cui fornisce indicazioni e suggerimenti di carattere pratico/operativo circa il modo più idoneo di crescere ed educare i figli, di promuovere e salvaguardare l'armonia del nucleo familiare, di orientare la prole in ordine alla vita cristiana e alla pratica religiosa, agli studi, al comportamento in società, al lavoro e alle scelte professionali ${ }^{173}$.

Un primo, parziale censimento di tali pubblicazioni, condotto da un gruppo di lavoro coordinato da chi scrive, ha permesso di individuare, relativamente al secolo XIX, oltre 500 opere riconducibili a tale genere ${ }^{174}$. Scritti con linguaggio piano, di veste tipografica ed editoriale modesta e di costo sovente irrisorio, questi trattatelli hanno conosciuto, dopo l'Unità e almeno fino alla prima guerra mondiale una diffusione crescente, testimoniata tra l'altro dalle frequenti ristampe e riedizioni (alcuni titoli registrano fino a mezza dozzina di riedizioni nell'arco di un sessantennio).

Due aspetti di tale pubblicistica minore meritano di essere segnalati: la cospicua presenza di testi dedicati alle famiglie contadine e redatti in genere da curati di campagna ${ }^{175}$, e la prevalente presenza, tra gli editori e/o stampatori di editrici cattoliche e di tipografie vescovili o appartenenti ad istituti religiosi (Salesiani, Scolopi, Gesuiti ecc.) ${ }^{176}$.

b) Per ciò che attiene alla veicolazione di modelli, stili educativi, pratiche formative destinati all'infanzia e alla gioventù, importanti spunti e indicazioni possono essere colti nella cosiddetta «letteratura devozionale». Si tratta, anche in questo caso, di un genere di pubblicazioni ancora poco frequentato dagli storici dell'educazione e dell'infanzia, sul quale ha

${ }^{173}$ A puro titolo esemplificativo, si vedano: S. Brigidi, L'educazione in famiglia, Firenze, Tip. Galileiana, 1867; Ammonimenti alle fanciulle cristiane, Milano, Tip. e Libreria Arcivescovile, 1870; La buona madre di famiglia, Torino, Tip. De Agostini, 1871²; G. Belluomini, Manuale delle madri cristiane, Siena, La Madre Cristiana, 1874; C. Calandrelli, L'istitutore novello in famiglia, Roma, Tip. Editrice Romana, 1877; C. Allario, Manuale delle madri di famiglia, Torino, Paravia, 1878; L.-E.-M. Bautain, La paternità cristiana. Istruzioni ad un padre, traduzione del sac. Francesco Bricolo, Treviso, Tip. Istituto Turazza, 1888; J.-J. Berthier, La madre secondo il cuore di Dio, ossia doveri della madre cristiana, Torino, Tip. Salesiana, 1890; Avvertenze, massime e riflessioni alla gioventù ed ai genitori... di un pio sacerdote, Ivrea, Tip. A. Tomatis, 1892; M. Bianchini, Guida alle madri cattoliche, Brescia, Tip. Queriniana, 1899.

${ }^{174}$ Presso il «Centro di documentazione e ricerca sulla storia del libro scolastico e della letteratura per l'infanzia» dell'Università degli Studi di Macerata è in corso di preparazione, a cura di chi scrive e di Anna Ascenzi, un repertorio delle fonti a stampa e delle pubblicazioni specificamente dedicate all'educazione familiare edite in Italia dal XVI al XIX secolo. Su questo tema, notevoli spunti sono contenuti anche in A. Ascenzi, Il Plutarco delle donne. Repertorio della pubblicistica educativa e scolastica e della letteratura amena destinate al mondo femminile nell'Italia dell'Ottocento, Macerata, EUM, 2009.

${ }^{175} \mathrm{Si}$ veda, ad esempio, il Calendario delle madri cristiane, Lodi, Tip. vescovile, 1898, 2 voll. (edito nella collana «Piccola biblioteca dei curati di campagna»).

${ }^{176}$ Particolarmente significativa su questo versante, specie nella seconda metà dell'Ottocento, è la presenza di opere stampate dalla Tip. Salesiana di Torino e dalla Tip. Queriniana di Brescia. 
richiamato l'attenzione, qualche anno fa, una studiosa della spiritualità, Annarosa Dordoni, in un importante saggio apparso negli «Annali di storia dell'educazione e delle istituzioni scolastiche» ${ }^{177}$.

Rivolta a tutti gli strati della popolazione e caratterizzata, anche nell'Otto e nel Novecento, da una diffusione amplissima ${ }^{178}$, la pubblicistica di carattere devozionale ha $\mathrm{i}$ suoi luoghi privilegiati di circolazione nelle parrocchie e nelle istituzioni di carattere religioso. Ai fini del nostro discorso, merita notare che essa si caratterizza non solo per la sua finalità di edificazione spirituale e di indirizzo all'esercizio delle pratiche devote, ma anche per il suo specifico intento educativo, ossia come strumento privilegiato per la trasmissione di indirizzi e modelli di comportamento coerenti con la fede cristiana. «I manuali di devozione - è stato efficacemente sottolineato - diventano così mezzi di trasmissione di valori religiosi e di princìpi etici, volti non solo a nutrire e ad irrobustire la vita di pietà dei singoli fedeli, ma ad orientare e a plasmare i comportamenti sociali. Regole e norme di vita [...] si presentano come brevi codici di comportamento [...] in cui princìpi cristiani e modelli normativi del vivere sociale spesso si intrecciano» ${ }^{179}$.

c) Un filone peculiare, nell'ambito della letteratura devozionale, è quello delle «agiografie popolari». Si pensi, in particolare, alle cosiddette Vite dei santi, un genere di pubblicazioni destinato precipuamente agli strati più bassi della popolazione con finalità di edificazione cristiana. Diffuse fin dalla tarda antichità, le Vite dei santi conobbero, all'indomani del Concilio di Trento, una nuova e più larga diffusione, in sintonia con $\mathrm{i}$ propositi di penetrazione cristiana tra le classi popolari e nelle campagne e di rinnovamento del costume e dei modelli di vita religiosa assunti dalla Chiesa nell'età confessionale $^{180}$. Dopo l'esperienza rivoluzionaria (nel corso della quale, fra l'altro, ci si sforzò di contrapporre a tali agiografie una pubblicistica d'intonazione laica e popolare, volta a celebrare e a proporre come «contromodelli» i cosiddetti «martiri della libertà e

177 Cfr. in proposito A. Dordoni, I libri di devozione dell'Ottocento (con particolare riferimento alla produzione milanese): proposte per una lettura critica, «Annali di storia dell'educazione e delle istituzioni scolastiche», I (1994), pp. 59-102; e Ead., I libri di devozione nell'800: una lettura critica, in Chiesa $e$ società a Bergamo nell'Ottocento, Milano, Glossa, 1998, pp. 203-234.

${ }^{178}$ A. Dordoni, I libri di devozione dell'Ottocento (con particolare riferimento alla produzione milanese): proposte per una lettura critica, cit., pp. 92-93. Si veda inoltre P. Stella, Produzione libraria religiosa e versioni della Bibbia in Italia tra età dei lumi e crisi modernista, in M. Rosa (ed.), Cattolicesimo e lumi nel Settecento italiano, Roma, Herder, 1981, pp. 99-125. Per il primo Novecento, si vedano anche i risultati dell'inchiesta promossa nel 1905 dalla Società bibliografica italiana: I libri più letti dal popolo italiano. Primi risultati dell'inchiesta promossa dalla Società bibliografica italiana, Milano, Società Bibliografica Italiana, 1906.

${ }^{179}$ A. Dordoni, I libri di devozione dell'Ottocento (con particolare riferimento alla produzione milanese): proposte per una lettura critica, cit., p. 85. Ma si vedano anche M. Marcocchi, Le dimensioni educative nella letteratura di pietà, in L. Pazzaglia (ed.), Cattolici, educazione e trasformazioni socio-culturali in Italia tra Otto e Novecento, Brescia, La Scuola, 1999, pp. 189-209; e R. Sani, Educational and mass market Catholic publishing in Italy between the two wars, in in «History of Education \& Children's Literature», II (2007), n. 2, pp. 217-238.

${ }^{180} \mathrm{Si}$ vedano in proposito S. Gajano Boesch, L. Sebastiani (edd.), Culto dei santi, istituzioni e classi sociali in età preindustriale, L'Aquila, Japadre, 1984; S. Gajano Boesch (ed.), Raccolte di vite dei santi dal XIII al XVIII secolo. Strutture, messaggi, fruizioni, Fasano, Schena, 1990; S. Gajano Boesch, L. Scaraffia (edd.), Luoghi sacri e spazi della santità, Torino, Rosenberg \& Sellier, 1990; G. Barone, M. Caffiero, F. Scorza Barcellona (a cura di), Modelli di comportamento e modelli di santità. Contrasti, intersezioni, complementarità, Torino, Rosenberg \& Sellier, 1994. 
della rivoluzione» ${ }^{181}$ ), e per tutto l'Ottocento, le Vite dei santi godettero di una rinnovata fortuna ed ebbero una circolazione destinata ad interessare un po' tutti gli strati della popolazione, sia urbana sia rurale.

Si tratta, anche in questo caso, di operette scritte con linguaggio semplice e piano, ricche di riferimenti al catechismo e alla pratica devota quotidiana, che mirano a colpire il sentimento e l'immaginazione, più che la ragione. Ai fini del nostro discorso merita notare che, non soltanto tali agiografie furono oggetto di lettura per "diletto" ed "edificazione" da parte della gioventù dei diversi ceti (come tali venivano proposte dai parroci, dai confessori ecc.), ma che, a partire dalla fine del Cinquecento e fino alla metà del secolo scorso, esse costituirono - assieme all'abecedario, al catechismo e all'àbaco - il "libro di testo" più diffuso nelle scuole popolari maschili e femminili tenute negli stati italiani preunitari dal clero e dai religiosi, come pure dai maestri laici privati ${ }^{182}$. Per secoli, dunque, le Vite dei santi hanno rappresentato uno dei principali strumenti di alfabetizzazione e di trasmissione di contenuti morali e di modelli e ideali educativi.

Ma c'è dell'altro: tale fonte assume particolare significato in quanto riflette una peculiare intenzionalità formativa. Le Vite dei santi, infatti, sono scritte ed utilizzate ai diversi livelli (da maestri, parroci, genitori) con il precipuo scopo di fornire al lettore ideali e modelli di comportamento, princìpi di condotta, indicazioni e suggerimenti circa il modo di operare nella vita. Occorre peraltro rilevare che l'agiografo costruisce la Vita del santo secondo un modello tipico, con una struttura narrativa che obbedisce a precisi stereotipi: l'esercizio delle virtù umane e cristiane, la pratica religiosa, il comportamento pubblico, il rapporto con il proprio corpo, l'atteggiamento di fronte alla malattia, alla sventura, alle difficoltà quotidiane; le scelte riguardo allo stato di vita e al futuro ecc. Proprio la sistematica e convenzionale riproposizione di tali aspetti e motivi in tutte le agiografie consente, ad esempio, di analizzare sul lungo periodo l'evoluzione di determinati ideali e modelli educativi, come pure la loro maggiore o minore incidenza sul costume e sulle pratiche formative.

In questo quadro un rilievo particolare riveste lo spazio (talora, come nelle Vite dei santi pubblicate nell'Ottocento, assai cospicuo) accordato nelle agiografie popolari alla narrazione dell'infanzia e della gioventù del santo, ovvero al «santo da bambino» ${ }^{183}$. Qui il proposito di fornire un modello di comportamento infantile da imitare si fa palpabile e il carattere ripetitivo e convenzionale delle narrazioni agiografiche consente allo storico di verificare la persistenza e/o il mutamento nel tempo di alcune dimensioni e caratteristiche dell'ideale educativo proposto per l'infanzia ${ }^{184}$.

${ }^{181}$ Cfr. C. Langlois, Les martyrs de la liberté comme contre-modèl, in G. Barone, M. Caffiero, F. Scorza Barcellona (edd.), Modelli di comportamento e modelli di santità, cit., pp. 415-429; e T. Tackett, La Révolution, l'Eglise, la France, Paris, Editions du Cerf, 1986, pp. 268-282.

${ }^{182} \mathrm{Al}$ riguardo, si veda ora R. Sani, «Ad Maiorem Dei Gloriam». Istituti religiosi, educazione e scuola nell'Italia moderna e contemporanea, Macerata, E.U.M., 2009.

${ }^{183}$ Cfr. A. Benvenuti Papi, E. Giannarelli (edd.), Bambini santi. Rappresentazioni dell'infanzia e modelli agiografici, Torino, Rosenberg \& Sellier, 1991, che però dedica scarsissima attenzione ai secoli XIX e XX.

${ }_{184}$ Oltre alle osservazioni formulate al riguardo in G. Barone, M. Caffiero, F. Scorza Barcellona (edd.), Modelli di comportamento e modelli di santità, cit., si vedano: S. Shahar, Infants, Infant care, and Attitudes toward Infancy in the Medieval lives of Saints, in «The Journal of Psycohistory», X (1983), n. 1, pp. 12-23; e M. Goodich, From Birth to Old Age, New York-London, Lanham, 1989. 
Sembra di poter dire infine che, per le sue caratteristiche, una fonte come le Vite dei santi si presta ad essere utilizzata anche per lumeggiare l'evoluzione sul lungo periodo della concezione del bambino e del più generale significato attribuito all'infanzia da parte del mondo adulto ${ }^{185}$.

\subsection{Prospettive di ricerca}

L'approfondimento del ruolo esercitato dalla Chiesa nel settore dell'assistenza e dell'educazione infantile in Italia tra Ottocento e Novecento implica, innanzi tutto, l'avvio di indagini sistematiche sulle diverse istituzioni ed esperienze di animazione religiosa e di catechesi promosse a livello diocesano e parrocchiale e destinate precipuamente all'infanzia e alla gioventù.

Si pensi, ad esempio, alla vasta e articolata rete di oratori parrocchiali, di scuole domenicali di catechismo, di associazioni di preghiera; come pure alle congregazioni mariane (in particolare quelle intitolate a S. Luigi Gonzaga e rivolte alla gioventù dei due sessi) e, più tardi, alle locali sezioni della gioventù maschile e femminile dell'Azione Cattolica.

Si tratta di istituzioni ed iniziative che hanno avuto una notevole incidenza sul piano educativo, ma sulle quali non disponiamo ancora di studi organici che consentano di valutarne appieno il tipo di proposta e i modelli formativi, l'incidenza a livello locale e sul piano nazionale, l'evoluzione istituzionale e degli indirizzi e programmi educativi sul lungo periodo $^{186}$.

La ricerca su tale versante potrebbe avvalersi della ricca documentazione, ancora in massima parte inesplorata, conservata negli archivi diocesani e, talora, delle singole parrocchie (per il periodo a noi più vicino), come pure della ricca messe di stampati, bollettini, pubblicazioni periodiche a carattere locale e nazionale promossi dagli eventuali organismi di coordinamento di tali iniziative (è il caso, ad esempio, degli oratori, delle congregazioni mariane e dei gruppi dell'Azione Cattolica).

Un ulteriore e importante filone d'indagine è quello relativo alle esperienze e iniziative degli Istituti religiosi maschili e, soprattutto, femminili che nel corso dell'Ottocento e del Novecento si sono dedicati precipuamente alla cura e all'assistenza dell'infanzia (asili, scuole materne, orfanotrofi ecc.), all'istruzione e all'educazione della

\footnotetext{
${ }^{185}$ Sull'opportunità di un utilizzo sistematico della letteratura agiografica in questo senso, anche al fine di verificare la «vecchia ipotesi di Philippe Ariès sull'assenza dell'infanzia nelle società tradizionali», si è espressa S. Vecchio nell'ampia recensione dedicata al volume Bambini santi. Rappresentazioni dell'infanzia e modelli agiografici, in «Cristianesimo nella storia», XV (1994), n. 1, pp. 197-200.

${ }^{186}$ Relativamente agli oratori parrocchiali disponiamo di alcune ricerche settoriali la cui impostazione metodologica, volta a far emergere e ad approfondire proprio il ruolo e le strategie di carattere educativo di tali istituzioni, ci sembra particolarmente efficace. Cfr. G. Barzaghi, Tre secoli di storia e pastorale degli Oratori milanesi, Leumann (Torino), LDC, 1985; G. Chiosso, L'oratorio di Don Bosco e il rinnovamento educativo nel Piemonte carloalbertino, in P. Braido (ed.), Don Bosco nella Chiesa a servizio dell'umanità. Studi e testimonianze, Roma, LAS, 1987, pp. 83-116; L. Caimi L'oratorio salesiano: la specificità di una proposta pedagogica, in Don Bosco. Ispirazione, proposte, strategie educative, Leumann (Torino), LDC, 1989, pp. 63-100; Id., Popolo e educazione cristiana: gli oratori (1945-'58), in L. Pazzaglia (ed.), Chiesa e progetto educativo nell'Italia del secondo dopoguerra 1945-1958, Brescia, La Scuola, 1988, pp. 210-238.
} 
gioventù dei diversi ceti (scuole, collegi, conservatori ed educandati femminili ecc.), all'animazione religiosa e alla catechesi. Su questo versante disponiamo già di pregevoli sintesi e di talune significative ricerche a livello locale, almeno per ciò che concerne il secolo XIX ${ }^{187}$.

E' pur vero, tuttavia, che molto resta ancora da fare, soprattutto in relazione all'opera assistenziale ed educativa svolta dalle congregazioni religiose nel Novecento nelle diverse aree del paese. Uno scavo sistematico della documentazione conservata presso gli archivi generalizi e quelli provinciali e locali dei diversi Istituti (regolamenti, programmi didattici ed educativi, elenchi dei libri di testo e di lettura, relazioni sulle attività formative svolte dalle singole istituzioni locali, statistiche sugli alunni e notizie sulla loro condizione e provenienza sociale ecc.), consentirebbe di valutare appieno le caratteristiche e dimensioni dell'opera assistenziale e formativa svolta dai religiosi e dalle diverse istituzioni e iniziative per l'infanzia da essi promosse.

In ultimo, ci sembra debba essere sottolineata l'importanza, ai fini del nostro discorso, di studi e ricerche dedicati al settore delle cosiddette Opere Pie, nel cui ambito, com'è noto, all'indomani dell'unificazione nazionale, furono inquadrate le molteplici e variegate istituzioni di beneficenza e assistenza sorte nei decenni precedenti per impulso di enti ecclesiastici e di benefattori privati ${ }^{188}$.

Tra queste figurano, ad esempio: gli asili infantili, gli istituti di ricovero per l'infanzia orfana e abbandonata (brefotrofi e orfanotrofi) e per la gioventù in condizioni di disagio (conservatori e ritiri per le giovani cosiddette "pericolanti" o "pericolate", riformatori per giovani "discoli", Case di lavoro), quelli destinati all'assistenza e all'educazione speciale (scuole e ricoveri per fanciulli e ragazzi sordomuti e ciechi) ${ }^{189}$.

Si tratta di una realtà di vaste dimensioni e d'indubbia importanza ai fini della comprensione delle modalità e caratteristiche dell'intervento assistenziale ed educativo (o rieducativo) per l'infanzia e la gioventù delle classi povere e disagiate nell'Italia unita. Una realtà, quella delle Opere Pie, che è stata finora studiata quasi esclusivamente sotto il

${ }^{187}$ Si vedano in proposito: G. Rocca, Le nuove fondazioni religiose femminili in Italia dal 1800 al 1860 , in Problemi di storia della Chiesa dalla Restaurazione all'unità d'Italia, Napoli, Dehoniane, 1985, pp. 107192; Id., Istituti religiosi in Italia tra Otto e Novecento, in Clero e società nell'Italia contemporanea, RomaBari Laterza, 1992, pp. 207-256; Id., Aspetti istituzionali e linee operative nell'attività dei nuovi istituti religiosi, in L. Pazzaglia (ed.), Chiesa e prospettive educative in Italia tra Restaurazione e Unificazione, Brescia, La Scuola, 1994, pp. 173-200; P. Borzomati, Le nuove congregazioni religiose nel Mezzogiorno e Annibale Di Francia, Roma, Studium, 1992; P. Braido (ed.), Esperienze di pedagogia cristiana nella storia. Vol. II: Sec. XVII-XIX, Roma, LAS, 1981; R. Sani (ed.), Chiesa, educazione e società nella Lombardia del primo Ottocento. Gli Istituti religiosi tra impegno educativo e nuove forme di apostolato (1815-1860), cit.; M.T. Falzone, Le congregazioni religiose femminili nella Sicilia dell'Ottocento, Caltanissetta, Sciascia, 2002; M. Taccolini (ed.), A servizio dello sviluppo. L'azione economico-sociale delle congregazioni religiose in Italia tra Otto e Novecento, Milano, Vita e Pensiero, 2004; R. Sani, "Ad Maiorem Dei Gloriam». Istituti religiosi, educazione e scuola nell'Italia moderna e contemporanea, cit.

${ }^{188}$ Cfr. S. Lepre, Le difficoltà dell'assistenza. Le opere pie in Italia fra '800 e '900, Roma, Bulzoni, 1988 (di carattere essenzialmente giuridico-amministrativo).

${ }^{189} \mathrm{Si}$ vedano ad esempio: R. Sani (ed.), L'educazione dei sordomuti nell'Italia dell'800. Istituzioni, metodi, proposte formative, Torino, SEI, 2008; S. Polenghi, Educating the cripples. The Pious Institute for rickets sufferers of Milan and its transformations (1874-1937), Macerata, EUM, 2009;M.C. Morandini, La conquista della parola. L'educazione dei sordomuti a Torino tra Otto e Novecento, Torino, SEI, 2010. 
profilo giuridico e amministrativo ${ }^{190}$, ma che meriterebbe ben altra attenzione da parte degli storici dell'infanzia e dell'educazione infantile.

Ma un'indagine a più vasto raggio, che si proponga di far emergere, al di là del pur cospicuo impegno sul terreno assistenziale ed educativo, il contributo offerto dalla Chiesa alla costruzione, nella società italiana dell'Otto e del Novecento, di una nuova "immagine" dell'infanzia, di un diverso "sentimento" degli adulti nei riguardi del mondo infantile rispetto ai secoli precedenti, deve necessariamente estendere la sua attenzione ad aspetti, modalità e piani dell'esperienza religiosa e della pratica devozionale troppo a lungo ignorati - o pregiudizialmente rifiutati - da certa storiografia sui "marginali" (identificati volta per volta con i bambini, le donne, i poveri, i folli ecc.), invero poco attenta al contesto socio-culturale e religioso entro il quale si colloca la concreta esperienza dei soggetti studiati.

Sono molti i segnali che testimoniano il maturare, già a partire dalla prima metà dell'Ottocento, di un nuovo «sentimento dell'infanzia» all'interno del cattolicesimo italiano:

- la crescente attenzione per i problemi dell'educazione e dell'istruzione infantile, con il conseguente superamento delle logiche meramente assistenziali proprie della fase precedente $^{191}$;

- l'emergere, sul piano della catechesi e della formazione cristiana della gioventù, di una sempre più larga attenzione ai dinamismi psicologici del fanciullo e all'esigenza di favorire una reale interiorizzazione della fede, cui fa riscontro il graduale abbandono degli indirizzi e dei modelli della catechesi tradizionale ${ }^{192}$;

- la progressiva diffusione di una spiritualità e di una pratica devozionale più in sintonia con le esigenze dei ceti popolari e maggiormente attente alla sensibilità propria dei fanciulli e dei ragazzi.

Basterebbe qui far cenno, ad esempio, al superamento dell'austera spiritualità di matrice rigorista tipica del Settecento e all'introduzione, fin dai primi anni dell'Ottocento, di una pietà cristiana che si nutre degli scritti spirituali di François de Sales, di Filippo Neri, di Alfonso Maria de' Liguori, e che riflette anche sul terreno educativo (nell'educazione dell'infanzia e della gioventù) motivi quali la dolcezza, l'amorevolezza,

\footnotetext{
${ }^{190}$ Si vedano in particolare: V. Fargion, L'assistenza pubblica in Italia dall'Unità al fascismo, in «Rivista trimestrale di scienza dell'amministrazione», XXIV (1983), n. 2, pp. 46-58; S. Lepre, Per una storia dell'attività dell'amministrazione statale nel settore dell'assistenza, in M. Bigaran (a cura di), Istituzioni e borghesie locali nell'Italia liberale, Milano, Franco Angeli, 1986, pp. 127-145; F. Della Peruta, Le Opere Pie dall'Unità alla legge Crispi, in Problemi istituzionali e riforme nell'età crispina. Atti del LV Congresso di storia del Risorgimento italiano (Sorrento, 6-9 dicembre 1990), Roma, Istituto per la Storia del Risorgimento Italiano, 1992, pp. 193-249.

${ }^{191}$ Significative indicazioni e conferme su questo versante, frutto di un approccio di tipo interdisciplinare e di un largo utilizzo di fonti inedite, sono venute ad esempio da una serie di convegni di studio dedicati all'approfondimento dell'impegno educativo della Chiesa italiana negli ultimi due secoli. Cfr. L. Pazzaglia (ed.), Chiesa e prospettive educative in Italia tra Restaurazione ed Unificazione, cit.; Id. (ed.), Chiesa e progetto educativo nell'Italia del secondo dopoguerra 1945-1958, cit.; Id. (ed.), Cattolici, educazione e trasformazioni socio-culturali in Italia tra Otto e Novecento, Brescia, La Scuola, 1999.

${ }^{192} \mathrm{Si}$ vedano A. Etchegaray, Storia della catechesi, Roma, Paoline, 1965; e, soprattutto, P. Braido, Lineamenti di storia della catechesi e dei catechismi. Dal «tempo delle riforme» all'età degli imperialismi (1450-1870), Leumann (Torino), LDC, 1991.
} 
la benignità, propri della prospettiva spirituale di quegli autori ${ }^{193}$; alla notevole fortuna e diffusione registrate dalle nuove devozioni centrate sulla famiglia e sull'infanzia, tra cui quelle alla Sacra Famiglia, all'Angelo custode, al Bambino Gesù, a San Giuseppe (cui si guarda come modello di carità e dolcezza paterna) ${ }^{194}$; infine, ad un'iconografia religiosa che si arricchisce di immagini infantili e familiari ${ }^{195}$.

Si tratta, naturalmente, di aspetti e motivi che necessitano di ulteriori verifiche e di approfondimenti. Non c'è dubbio, tuttavia, che essi testimoniano il maturare di una nuova sensibilità pastorale ed educativa all'interno della Chiesa, destinata ad influire sulla stessa percezione dell'infanzia e dei suoi problemi.

In un importante lavoro sulla mentalità religiosa pubblicato qualche anno fa, Marina Caffiero ha avanzato l'ipotesi di una sorta di «femminilizzazione del cattolicesimo tra Settecento e Ottocento» ${ }^{196}$. Questa ipotesi ci sembra interessante, così come suggestivo appare il fatto che tale processo di «femminilizzazione del cattolicesimo» si sia verificato in una fase storica che ha registrato il graduale affermarsi, a tutti i livelli (istituzionale, giuridico, economico, della stessa sfera dei comportamenti privati), dell'autoritarismo e del paternalismo di matrice borghese. Riteniamo che anche la ricerca storica sull'infanzia e sulla sua educazione debba misurarsi con tale profondo mutamento del costume ecclesiastico e pastorale e con le più generali trasformazioni che hanno contrassegnato la cultura e l'esperienza religiosa del nostro paese tra Otto e Novecento.

193 Cfr. M. Marcocchi, Indirizzi di spiritualità ed esigenze educative nella società post-rivoluzionaria dell'Italia settentrionale, in L. Pazzaglia (ed.), Chiesa e prospettive educative in Italia tra Restaurazione e Unificazione, cit., pp. 83-122; M. Petrocchi, Schema per una storia della spiritualità italiana nell'Ottocento e nel Novecento, ora in Id., Storia della spiritualità italiana, introduzione di P. Borzomati, Torino, SEI, 1996, pp. 244-274; R. Sani, Indirizzi spirituali e proposte educative dei nuovi Istituti religiosi dell'Ottocento in area lombarda, in Id. (ed.), Chiesa, educazione e società nella Lombardia del primo Ottocento. Gli Istituti religiosi tra impegno educativo e nuove forme di apostolato (1815-1860), cit., pp. 77-138.

${ }^{194} \mathrm{Si}$ vedano al riguardo M. Bendiscioli, La pietà specialmente del laicato sulla scorta dei manuali di devozione diffusi nell'Italia settentrionale, in Chiesa e religiosità in Italia dopo l'Unità (1861-1878), Milano Vita e Pensiero, 1973, 3 voll., II, pp. 154-176; P. Stella, Don Bosco nella storia della religiosità cattolica, Zurigo, PAS, 1968-1969, 2 voll.; Id., Prassi religiosa, spiritualità e mistica nell'Ottocento, in G. De Rosa, T. Gregory, A. Vauchez (edd.), Storia dell'Italia religiosa. 3. L'età contemporanea, Roma-Bari, Laterza, 1995, pp. 115-142; e, in particolare, il già ricordato A. DORDONI, I libri di devozione dell'Ottocento (con particolare riferimento alla produzione milanese): proposte per una lettura critica, cit., pp. 59-67.

${ }^{195}$ Cfr. A. Vecchi, Il culto delle immagini nelle stampe popolari, Firenze, Olschki, 1968; M. Falzone del Barbarò, Santi di pizzo. Immagini su carta intagliata dal XVII al XX secolo, Torino, D. Piazza, 1983; Con mano devota. Mostra delle immaginette spirituali manufatte, Padova, Edizioni Messaggero, 1985; M.T. Beife Casella, L'immaginetta di devozione strumento di divulgazione della dottrina cristiana (secoli XVIII-XIX), in Chiesa e società a Bergamo nell'Ottocento, cit., pp. 235-254.

196 M. Caffiero, Un santo per le donne. Benedetto Giuseppe Labre e la femminilizzazione del cattolicesimo tra Settecento e Ottocento, «Memoria», 30 (1990), 3, pp. 89-106. Della stessa autrice si vedano inoltre: Ead., Femminile/popolare. La femminilizzazione religiosa nel Settecento tra nuove congregazioni e nuove devozioni, «Dimensioni e Problemi della Ricerca storica», 2 (1994), pp. 235-245; Ead., La politica della santità. Nascita di un culto nell'età dei Lumi, Roma-Bari, Laterza, 1996, specie p. 183 e ss. Per un quadro dei riflessi di tale fenomeno sulla vita pastorale e sulla pratica religiosa dell'Otto e del Novecento, con particolare riferimento alla realtà francese, si veda Histoire religieuse de la France XIXe-XXe siècle, sous la direction de J.-M. Mayeur, Paris, Beauchesne, 1975. 